CLAUDIA LOPES DA SILVA

\title{
O PAPEL DO DIRETOR ESCOLAR NA IMPLANTAÇÃO DE UMA CULTURA EDUCACIONAL INCLUSIVA A PARTIR DE UM ENFOQUE SÓCIO-HISTÓRICO
}

SÃO PAULO 2006 


\section{CLAUDIA LOPES DA SILVA}

\section{O PAPEL DO DIRETOR ESCOLAR NA IMPLANTAÇÃO DE UMA CULTURA EDUCACIONAL INCLUSIVA A PARTIR DE UM ENFOQUE SÓCIO-HISTÓRICO}

Dissertação apresentada ao Instituto de Psicologia da Universidade de São Paulo, como parte dos requisitos para a obtenção do título de Mestre em Psicologia.

Área de concentração: Psicologia Escolar e do Desenvolvimento Humano

Orientadora: Prof ${ }^{a}$. Dr ${ }^{a}$. Maria Isabel da Silva Leme

SÃO PAULO

2006 


\section{AUTORIZO A REPRODUÇÃO E DIVULGAÇÃO TOTAL OU PARCIAL DESTE TRABALHO, POR QUALQUER MEIO CONVENCIONAL OU ELETRÔNICO, PARA FINS DE ESTUDO E PESQUISA, DESDE QUE CITADA A FONTE.}

Catalogação na publicação Serviço de Biblioteca e Documentação Instituto de Psicologia da Universidade de São Paulo

Silva, Claudia Lopes da.

O papel do diretor escolar na implantação de uma cultura educacional inclusiva a partir de um enfoque sócio-histórico / Claudia Lopes da Silva; orientadora Maria Isabel da Silva Leme. -- São Paulo, 2006.

$143 \mathrm{p}$.

Dissertação (Mestrado - Programa de Pós-Graduação em Psicologia. Área de Concentração: Psicologia Escolar e do Desenvolvimento Humano) - Instituto de Psicologia da Universidade de São Paulo.

1. Inclusão escolar 2. Administração educacional 3. Ambiente escolar I. Título. 


\section{O PAPEL DO DIRETOR ESCOLAR NA IMPLANTAÇÃO DE UMA CULTURA EDUCACIONAL INCLUSIVA A PARTIR DE UM ENFOQUE SÓCIO-HISTÓRICO}

CLAUDIA LOPES DA SILVA

Nome do examinador

Nome do examinador

Nome do examinador

Nome do examinador

Nome do examinador
Assinatura

Assinatura

Assinatura

Assinatura

Dissertação defendida e aprovada em /2006 
Fifi,

Toda saudade é a presença

Da ausência de alguém

De algum lugar

De algo enfim

Súbito o não

Toma forma de sim

Como se a escuridão

Se pusesse a luzir

Da própria ausência de luz

O clarão se produz

O sol na solidão

(Gilberto Gil) 


\section{Agradecimentos}

Gostaria de agradecer ao Instituto de Psicologia da Universidade de São Paulo por ter-me proporcionado esta oportunidade, pela qual tenho imenso orgulho e profunda gratidão: um sonho tornou-se realidade;

À minha orientadora, Prof ${ }^{a}$. Dr ${ }^{a}$. Maria Isabel da Silva Leme, por sua atenção, abertura e disponibilidade para a conversa franca, com verdadeiro espírito científico;

Às professoras que atenciosamente fizeram parte da banca de qualificação e de defesa, Prof ${ }^{a}$. Dr ${ }^{a}$. Marilene Proença Rebello de Souza e Prof ${ }^{a}$. Dr ${ }^{a}$. Rosângela Gavioli Prieto, por seus ensinamentos e orientações valiosas, que compartilham generosamente;

À Prof ${ }^{\mathrm{a}}$. Dra . Elenita de Rício Tanamachi, pelo seu espírito lutador, de grande incentivo para todos que têm a oportunidade de com ela conviver, bem como à Prof $^{\mathrm{a}}$. Dr ${ }^{\mathrm{a}}$. Marie Claire Sekkel, por seu trabalho inspirador e dedicação à causa da educação inclusiva;

Aos meus colegas de trabalho, especialmente aos psicólogos e fonoaudiólogos, companheiros na busca pela fronteira justa e libertadora entre a saúde e a educação, e à Yara Sayão, farol em tempos tempestuosos, com quem sempre reaprendo a ter esperanças; 
Aos profissionais da educação com quem convivo diariamente: professores, coordenadores e diretores, com especial carinho para Ana Paula, pela generosidade. Com ela compartilho uma paixão especial por uma certa escola, sofrida e muito querida;

Aos alunos que acompanho, cujos progressos persigo com alegria e determinação: não posso desistir de legar-lhes uma escola e um mundo mais justos;

Às minhas queridas irmãs, Paula e Rosana; à princesa Flora, minha dileta e predileta sobrinha; à mamãe e titi Lucy, que com amor e humor superam dores, e à memória da nossa maravilhosa Fifi, aqui e agora e sempre conosco;

Ao Silvio, meu amor. 
Na minha rua há um menininho doente.

Enquanto os outros partem para a escola, Junto à janela, sonhadoramente, Ele ouve o sapateiro bater sola.

Ouve também o carpinteiro, em frente, que uma canção napolitana engrola.

E pouco a pouco, gradativamente, o sofrimento que ele tem se envola...

Mas nesta rua há um operário triste: Não canta nada na manhã sonora E o menino nem sonha que ele existe.

Ele trabalha silenciosamente...

E está compondo este soneto agora, pra alminha boa do menino doente...

Mário Quintana
Eu preparo uma canção
que faça acordar os homens
e adormecer as crianças.

Carlos Drummond de Andrade 


\section{Sumário}

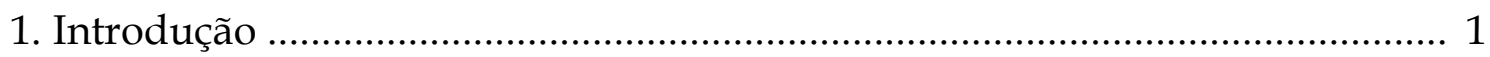

2. Cultura, deficiência e educação inclusiva ...................................................... 10

2.1. O conceito de cultura e cultura escolar: a escola enquanto

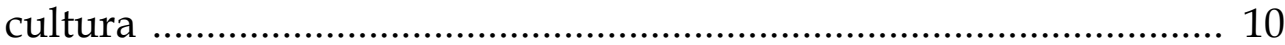

2.2. Estar na escola como condição de humanização ......................... 21

2.3. Vigotski e a defectologia ............................................................. 26

2.4. A deficiência como produção social ............................................. 38

2.5. O conceito de ambiente inclusivo ............................................... 39

2.6. Educação inclusiva: definição e questões atuais ......................... 45

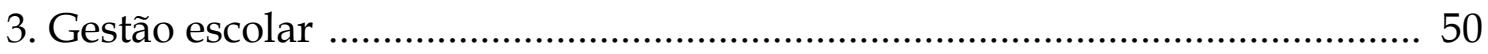

3.1. O diretor escolar ........................................................................... 50

3.2. O diretor enquanto articulador de mudanças: em busca de uma

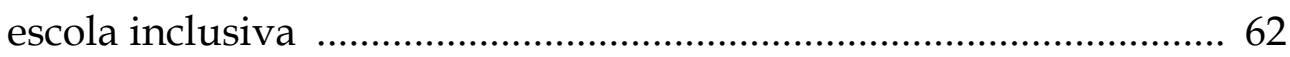

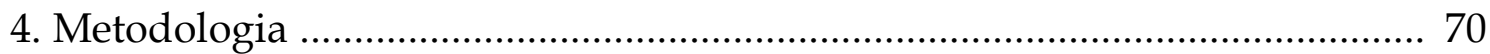

4.1. Metodologia de pesquisa ........................................................... 70

4.2. Porque pesquisar a instituição escolhida ..................................... 73

4.3. Pesquisa documental ............................................................ 86

4.3.1 Projeto pedagógico da escola .............................................. 88

4.4. Entrevista ………………………............................................ 93

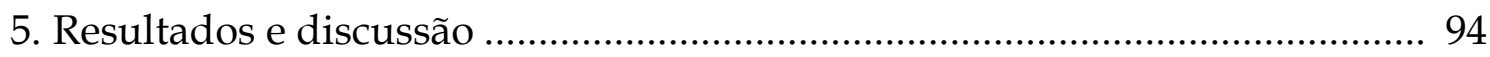

5.1. Análise da entrevista ................................................................... 94

5.2. Primeiro momento: temas emergentes da entrevista ................... 97

5.3. Segundo momento: o tema de fundo e os focos de análise ..... 118

6. Algumas conclusões possíveis ................................................................... 124

7. Referências bibliográficas ........................................................................ 132 
SILVA, C. L. O papel do diretor escolar na implantação de uma cultura educacional inclusiva a partir de um enfoque sócio-histórico. Dissertação (mestrado). Instituto de Psicologia da Universidade de São Paulo. São Paulo, 2006.

\section{RESUMO}

Este trabalho investiga o papel do diretor escolar na formação de uma cultura escolar inclusiva tendo como base teórica a psicologia sócio-histórica de Vigotski. Investigaram-se os conceitos de cultura escolar, educação inclusiva e ambiente inclusivo, de forma a estabelecer a importância do contexto da escola na inclusão escolar de alunos com deficiência, bem como o conceito de gestão escolar, com foco na atuação do diretor. Como hipótese de pesquisa, considerou-se que a opinião pessoal, aspirações, atitudes, concepção de educação, compromisso ético-profissional, enfim, os aspectos idiossincráticos do diretor influenciam de maneira decisiva a forma como se constitui a cultura escolar e facilitam ou dificultam a implantação da inclusão escolar de alunos com necessidades educacionais especiais. Propõe-se que isso se deva em grande parte à liderança e autoridades conectadas ao papel central que o diretor exerce na instituição escolar, bem como se relaciona com as dificuldades que a democratização dos processos de gestão escolar encontra para uma atuação efetiva. O papel do diretor enquanto um articulador do projeto pedagógico sobre o qual deve estar apoiado o projeto da escola tornar-se inclusiva seria então fundamental. A pesquisa busca estabelecer uma relação entre a democratização da escola e a implantação de uma cultura escolar inclusiva, através da atuação do diretor escolar. O trabalho apresenta-se como um estudo de caso, tendo sido utilizados como procedimentos de pesquisa o relato de experiência, a análise documental e a entrevista com uma diretora escolar. Como resultados, concluiu-se que a democratização da gestão e a educação inclusiva se relacionam de forma importante, sugerindo-se que uma escola inclusiva é, antes de tudo, uma escola democrática. Propõe-se investir na produção de contextos escolares que favoreçam a construção de práticas democráticas, bem como que os sistemas educacionais assumam sua importante cota de responsabilidade nesta tarefa.

Descritores: inclusão escolar, administração educacional, ambiente escolar. 
SILVA, C. L. The school principal's role into the achievement of an inclusive educational culture: a study from a social and historical prespective. Dissertation (master's degree). Psychology Institute - São Paulo University. São Paulo, 2006.

\begin{abstract}
The present work investigates the school principal's role into the formation of an inclusive schooling culture. The approach is theoretically based on Vigotski's social-historical psychology. The research includes the concepts of school culture, inclusive education and inclusive environment, as a way of establishing school's context relevance to school inclusion of students with special needs, and the concept of school management focusing the principal's action towards inclusion. It was taken as research hypothesis that the principal's idiosyncratic qualities, such as personal opinions, aspirations, education concept, ethical and professional commitment exert decisive influence on how the school culture is constituted, which facilitates or not school inclusion of students with educational special needs. It is proposed that this might be largely due to leadership and authority, connected to the central role of the principal at the school institution, as well as to difficulties to accomplish an effective democratization of the school management processes. The principal's role as an articulator of the pedagogical project, on which the school project of being inclusive must be supported would be then fundamental. The research aims to establish relationships between the school democratization process and the implantation of an inclusive school culture, through school principal's action. The research was conducted as a case study, applying as its procedures the researcher's report, the documental analysis and an interview with the principal of the school. Results favored the conclusion that the management democratization process and the inclusive education are related in a very important way, suggesting that an inclusive school is, above all, a democratic school. It is proposed that it is important to invest into the production of school contexts that promote the construction of democratic actions, as well as it is relevant that the educational systems take responsibility of its role in this task.
\end{abstract}

Key words: school inclusion, educational administration, school environment. 


\section{Introdução}

Escola é o lugar aonde a gente vai quando não está de férias.

A chefe da escola é a diretora.

A diretora manda na professora.

A professora manda na gente.

A gente não manda em ninguém.

Só quando manda alguém plantar batata.

(Escola - José Paulo Paes)

Dia 17 de janeiro de 2000 - meu primeiro dia de trabalho na equipe técnica da secretaria de educação e cultura de uma cidade da região metropolitana de São Paulo1, tendo sido admitida após ter prestado concurso público para psicóloga escolar. Eu deveria estar lá às $8 \mathrm{~h}$, mas havia chegado muito mais cedo. Timidamente, conversava com alguns futuros colegas: "você é psicóloga? Eu também!".

Um pequeno grupo ia se formando na recepção do prédio. Fomos recebidos pela equipe técnica do Ensino Fundamental que, até então, consistia em quatro pessoas (três pedagogas e uma assistente social). A equipe estava acabando de nascer, como uma das condições colocadas pelo processo de municipalização do Ensino Fundamental I (quatro primeiros anos do ensino

\footnotetext{
1 O nome da cidade será omitido, pois a pesquisa foi realizada neste município. Os dados que poderiam identificar a cidade foram suprimidos ou alterados sem que o conteúdo fosse substancialmente modificado. Os nomes citados são fictícios, de forma a não revelar a identidade dos envolvidos.
} 
fundamental) que se iniciara na cidade em 1998, o que justificava porque estávamos sendo chamados.

Recepção, pronunciamentos, expectativas de ambas as partes, café da manhã, programação de visitas às escolas, tudo parecia muito bem cuidado para nos acolher, e respondíamos com solicitude a este atencioso tratamento.

Em dado momento, fomos encaminhados a uma sala com uma grande mesa de reuniões. O grupo era pequeno, cerca de doze pessoas. Começaram as apresentações. Nessas, descobri que entre as pessoas do grupo encontravam-se três diretores escolares, que foram chamados concomitantemente a nós. Fiquei surpresa, pois, com o edital do concurso que havia prestado em mente, achei que no grupo só havia psicólogos, fonoaudiólogos e orientadores pedagógicos. Refletindo mais detidamente sobre o que senti, percebi que no fundo estava incomodada com a presença daquelas três pessoas. Por quê?

Nas conversas de corredor, logo fui perguntando se estaríamos subordinados aos diretores na escola - não sabia ainda que minha sede seria na secretaria, e não nas unidades escolares. Informavam-me que não, e eu respirava aliviada. Por quê?

Em busca da resposta, pensei logo nos textos clássicos da psicologia escolar, onde se narravam as dificuldades que o psicólogo encontra em sua atuação devido aos entraves institucionais da escola, mas um leve ruído ia surgindo no pano de fundo desses pensamentos. Quanto mais eu racionalizava, mais alto o barulhinho ficava, repetitivo, uma torneirinha da memória pingando...

Subitamente, vi-me no pátio da escola municipal onde estudei da $4^{\mathrm{a}}$ à $8^{\mathrm{a}}$ séries, nos anos de 1975 a 1979. Estávamos todos alinhados em 
fila, imagem comum naqueles anos de ditadura e, infelizmente, ainda encontrada em algumas escolas (em muitas...). O barulho do salto de Dona Doroti podia ser ouvido devido ao silêncio que os alunos faziam, misto de respeito e medo - muito mais medo que respeito.

Calmamente, Dona Doroti dirigiu-se ao palco, subiu, e começou a fazer uma preleção aos alunos a respeito da forma com que usávamos o papel higiênico no banheiro (tinha papel higiênico nos banheiros da escola pública naquela época). Depois de relatar vários usos inadequados do papel, como fazer bolinhas e jogar no teto (eu, ingênua, nunca havia notado isso, e confesso que depois de Dona Doroti ter-me revelado essa possibilidade, fiquei com muita vontade de arremessar bolotas do papel molhado ao teto. $\mathrm{O}$ sentimento de opressão que sempre acompanhou-me na escola, contudo, impedir-me-ia completamente de cometer tal ato), Dona Doroti ensinou-nos como deveríamos usar o papel higiênico sem desperdícios: deveríamos cortar um pedaço equivalente a três picotes, e então dobrá-lo em três partes, o que seria suficiente para nos secar - nós, as meninas. Sobre os meninos não lembro acho que Dona Doroti não considerava a hipótese deles utilizarem papel higiênico após urinar. Se por acaso quiséssemos fazer algo além de urinar, então Dona Doroti recomendava que usássemos quatro picotes, com o papel dobrado nos mesmos, e assegurava-nos que isso era o suficiente.

Os trinta anos dessa lembrança não impediram que ela surgisse tão forte!

Ao escrever essa apresentação, fico pensando nos motivos de Dona Doroti. A boa arte de administrar - é conhecida a máxima de que "governar é gerir recursos escassos". Mas é provável, também, que o objetivo de Dona Doroti fosse educar, ensinar a nós, alunos da escola pública, corretas regras de higiene que certamente não nos haviam ensinado em casa - se nos ensinassem, por certo, Dona Doroti economizaria o discurso (além de papel 
higiênico). Nunca passou pela minha cabeça - e por certo também não pela de Dona Doroti - a idéia de diversidade associada ao uso de papel higiênico nossos corpos eram diferentes, nossas eliminações também, porque haveríamos de usar um pedaço do mesmo tamanho? Acaso todo dia precisaríamos usar um pedaço deste tamanho? Não poderíamos ter diferentes necessidades? E porque sermos assim tutelados, acaso não seríamos capazes de gerir com bom senso o uso do papel higiênico? Certamente Dona Doroti acreditava que não, nem via no uso indevido dos materiais escolares outra coisa além de falta de educação. Segundo Gusmão (2003, p. 93),

é freqüente se ouvir que naquela escola todos são iguais e que aos olhos do educador não há diferença. No entanto, todos sabemos que esta igualdade não é real. [...] Por que, então, os dizemos iguais? Porque todos ali são vistos a partir do lugar que ocupam no interior da escola. Ali eles são alunos, categoria geral e abstrata que, tal como a categoria índio, coloca a todos no mesmo saco e nega as diferenças que os tornam, cada um, sujeitos socioculturais.

Sei que esse relato é prosaico e um tanto desconcertante talvez vagamente patético, mas o fato é que estava lá no baú da memória e ressurgiu nessa reflexão. Pude perceber então porque a presença daquelas três pessoas desconhecidas incomodava-me tanto: diretores me incomodavam. Os diretores me lembravam da Dona Doroti, e apesar de não ter tido muitas experiências de convívio direto com eles, por ter sempre sido uma aluna "disciplinada" - leia-se oprimida -, sua presença causava-me um vago mal estar, um desconforto.

Como disse, tive pouquíssimos encontros com diretores quando era aluna, e é interessante como me marcaram. Um deles merece também ser relatado, pela sua pertinência aos temas que aqui serão abordados. Certa vez minha professora mandou-me à sala da Dona Doroti para entregar algo, o que me fez ficar ansiosa e caminhar até lá com um frio na barriga. Ao 
chegar, vi na parede um quadro de linhas tecidas em preguinhos que eu havia feito. Eu tinha feito este trabalho para uma aula de Educação Artística; ele foi para uma exposição e nunca voltou, e ninguém sabia me dizer o que havia acontecido (eu, certamente, não perguntei muito). Com surpresa, descubro o paradeiro do quadro: a sala da diretora! Senti-me orgulhosa, e não consigo lembrar se tive coragem suficiente para dizer a ela que eu havia feito o quadro. Lembro de ter contado o fato com alegria para minha mãe, que também ficou contente. Afinal, o mistério do quadro sumido havia sido esclarecido, ainda que eu não esperasse que fosse, pois estas negligências eram comuns na escola. Somente muitos anos depois é que fui capaz de pensar que Dona Doroti nem perguntou para mim se ela poderia ficar com o quadro - por que deveria? Afinal, era um trabalho de um ALUNO. O que um aluno teria para dizer? Imagino que se ela me perguntasse eu ficaria honrada e feliz em dar-lhe o quadro, mas não passou pela cabeça dela, pela minha ou pela da minha mãe que isso fosse necessário.

Essa historinha trivial mostra um pouco como as relações se estabeleciam e se estabelecem na escola: fortemente hierarquizadas, autoritárias e centradas na figura do diretor. Aquele vago mal-estar sentido na sala de reuniões em relação aos diretores, que não eram nem mesmo meus superiores hierárquicos naquele momento havia sido historicamente construído e seus ecos em mim ressoavam; muito provavelmente as pessoas naquela sala, incluindo os diretores, também teriam vivenciado situações semelhantes.

Saltemos na história para o ano de 2003, quando fazia especialização em psicologia escolar no Instituto de Psicologia da Universidade de São Paulo. Estava procurando um tema para a monografia que deveria ser feita como parte dos requisitos para conclusão do curso. O tema inclusão escolar já me interessava e era recorrente em meu trabalho, e pensava em fazer algo sobre o assunto. Na época, eu coordenava um grupo de trabalho sobre inclusão escolar na rede municipal em que trabalho, envolvendo representantes 
das equipes técnicas da educação infantil, ensino fundamental, educação especial e educação de jovens e adultos. Durante todo o ano, as equipes integrantes da secretaria passaram por um grande processo de discussão, existindo outros grupos de discussão para temas como articulação entre as equipes, formação e papel da equipe técnica.

Devido ao fato de coordenar um dos grupos de discussão, fui convidada a participar de uma reunião com diretores e professores coordenadores, onde foi distribuído um instrumento para ser preenchido que perguntava sobre a visão do papel dos técnicos pelos diretores. Como é comum em reuniões desse tipo, houve muitas críticas ao processo, com os participantes apontando as eternas questões estruturais, falta de pessoal, falta de participação nos grupos para definir o papel dos técnicos, enfim, várias queixas. Logo imaginei que estar presente nessa reunião não era uma boa estratégia, pois, de alguma forma, poderia inibir as manifestações dos participantes, afinal o grupo discutia, entre outras questões, qual o papel na escola do psicólogo da equipe técnica.

A reunião foi bastante tensa e, após o encerramento, auxiliei na tabulação do instrumento preenchido pelos gestores. Confesso que fiquei inquieta com o que li, pois as respostas eram duras, algumas beirando a grosseria, preconceituosas e carregadas da visão clínica sobre o papel do psicólogo no sentido de diagnosticar, encaminhar e tratar os alunos como problemas individuais. Acabei optando, como uma forma de elaborar esta questão internamente do ponto de vista pessoal e teórico, por pesquisar o papel do psicólogo escolar na visão dos gestores. Dessa forma, entrei de maneira mais sistemática na pesquisa sobre gestão escolar.

Em 2004, já como mestranda, e discutindo com minha orientadora sobre os rumos que escolheria para a elaboração da dissertação, a temática dos diretores escolares ressurgiu. O tema, de acordo com minha 
orientadora, ainda estava pouco explorado, além do que seria uma oportunidade de aprofundar a pesquisa iniciada no curso de especialização. Meu projeto de mestrado versava sobre educação inclusiva numa abordagem sócio-histórica, e a pesquisa com gestores seria uma forma interessante de realizar um recorte nessa ampla temática. Assim, o projeto foi tomando forma, que poderia ser descrita de maneira resumida na pesquisa do papel do diretor dentro de um enfoque sócio-histórico, abordagem que detalharei oportunamente, mas que pode ser sintetizada a partir de orientações metodológicas propostos por Vigotski, onde a análise dos processos é enfatizada em relação à análise do objeto em suas características isoladas, em que se buscam relações dinâmicas ao invés de análise puramente descritivas, e se procura reportar às origens de cada processo, visando compreender seus desdobramentos historicamente (Vygotsky², 1988).

A partir destas considerações, o objetivo geral deste trabalho é investigar o papel do diretor escolar na formação de uma cultura escolar inclusiva a partir de uma abordagem sócio-histórica.

Como hipótese de pesquisa, considera-se que a opinião pessoal, aspirações, atitudes, concepção de educação e compromisso éticoprofissional assumido, enfim, os aspectos idiossincráticos do diretor influenciam de maneira decisiva a forma como se constitui a cultura escolar e facilitam ou dificultam a implantação da inclusão escolar de alunos com necessidades educacionais especiais. Imagina-se que isso se deva em grande parte à liderança e autoridades conectadas ao papel central que o diretor exerce na instituição escolar, bem como relaciona-se com as dificuldades que a democratização dos processos de gestão escolar encontra para uma atuação

\footnotetext{
2 Neste trabalho, emprega-se a grafia Vigotski, por ser a utilizada nas traduções mais recentes da obra do autor. Outras publicações, contudo, utilizam diferentes grafias (como Vygotsky), que, ao serem aqui referidas, serão preservadas em sua apresentação original, o que impedirá a padronização do nome do autor nas citações feitas neste trabalho. Para maiores detalhes sobre esta questão, sugere-se a consulta de DUARTE, N. Vigotski e o aprender a aprender. 2 ed. Campinas: Autores Associados, 2001. Nota de rodapé p. 2-3.
} 
efetiva. O papel do diretor enquanto um articulador do projeto pedagógico sobre o qual deve estar apoiado o projeto da escola tornar-se inclusiva seria então fundamental. Assim, não se pretende negar a importância do papel central do diretor, mas considerá-lo de forma que se coloque a serviço da democratização da escola, o que parece fundamental para a efetivação de uma cultura educacional inclusiva.

Este estudo procura contribuir para tanto, tendo, desta forma, uma finalidade emancipatória, no sentido em que entende a gestão escolar como motor para a articulação de processos e dos envolvidos professores, funcionários, alunos e comunidade - na busca de uma construção democrática que respeite o direito de todos os seres humanos no acesso aos bens sociais e culturais acumulados pela humanidade, sendo assim tratados em todas as situações, sobretudo durante sua escolarização, independente de sua condição cultural, econômica, social, étnica, religiosa, psicológica, física ou mental, bem como outras possibilidades.

Apresenta-se a seguir uma revisão da literatura sobre a temática, onde se procurou selecionar trabalhos atuais sobre o tema gestão escolar, enfatizando autores cuja concepção seja convergente com a psicologia sócio-histórica, uma vez que se pretende fundamentar a definição de um ambiente escolar favorável à inclusão de todos os alunos na teoria de Vigotski.

Na revisão da literatura, optou-se por um percurso que atravessasse alguns temas considerados importantes para a compreensão do recorte pretendido. Estes temas foram divididos em dois capítulos, descritos a seguir.

Inicialmente, no capítulo "Cultura, deficiência e educação inclusiva", buscaram-se algumas definições sobre o conceito de cultura, partindo das mais clássicas, ligadas à antropologia, e chegando às definições de cultura escolar. Em seguida, procurou-se estabelecer algumas relações na teoria 
de Vigotski sobre o papel da cultura e da sociedade na formação do indivíduo, enfatizando o papel da escola em sua socialização enquanto instância mediadora entre este e a sociedade. Nessa acepção, procura-se enfocar as contribuições feitas por Vigotski no campo da assim chamada defectologia, ou o estudo do desenvolvimento infantil influenciado pela deficiência ${ }^{3}$. Também discorreu-se sobre a produção social da deficiência a partir da contribuição de Omote (1994). Merece destaque aqui o conceito de ambiente escolar inclusivo proposto por Sekkel (2003), articulado com a teoria sócio-histórica a fim de compreender a importância do contexto na constituição de uma cultura inclusiva. Na seqüência, foram selecionadas algumas definições sobre educação inclusiva e necessidades educacionais especiais, onde procurou-se tecer algumas reflexões sobre o papel do diretor escolar na democratização da escola pela via da inclusão de alunos com necessidades educacionais especiais, destacando-se entre esses os alunos com deficiência.

Por fim, no capítulo "Gestão escolar", passou-se a discutir conceitos relacionados ao diretor escolar do ponto de vista pedagógico e organizacional, de forma a complementar a pesquisa sobre cultura escolar, com a finalidade de procurar compreender como o diretor se relaciona com essa cultura, de que forma a determina e é por ela determinado, e qual é a importância do seu papel para a efetivação de uma educação inclusiva.

\footnotetext{
3 A definição de deficiência, segundo a Organização Mundial de Saúde (OMS), é a de "qualquer perda ou anormalidade da estrutura ou função psicológica, fisiológica ou anatômica”. O decreto $\mathrm{N}^{0} 3.298 / 99$, que dispõe sobre a Política Nacional para a Integração da Pessoa Portadora de Deficiência, define deficiência, em seu artigo $3^{\circ}$, como "toda perda ou anormalidade de uma estrutura ou função psicológica, fisiológica ou anatômica que gere incapacidade para o desempenho de atividade, dentro do padrão considerado normal para o ser humano". Para Vigotski, o conceito de deficiência se fundamenta em sua particularidade qualitativa em relação ao desenvolvimento infantil normal, não considerando-a como uma função menos desenvolvida: "a criança cujo desenvolvimento está complicado pelo defeito não é simplesmente uma criança menos desenvolvida que seus coetâneos normais, e sim desenvolvida de um outro modo." (VIGOTSKI, 1929, p. 12, grifos do autor).
} 


\section{2}

\section{Cultura, deficiência e educação inclusiva}

\subsection{O conceito de cultura e cultura escolar: a escola enquanto cultura}

Conceituar cultura é tarefa bastante complexa, dada sua importância como conceito básico em ciências como a antropologia, a educação, a sociologia e a psicologia, para citar algumas áreas mais intimamente relacionadas com o presente estudo. Assim, não se alimenta a pretensão de abarcar neste trabalho as inúmeras definições existentes, mas sim efetuar uma pequena seleção de algumas definições mais clássicas de forma a iniciar um percurso na definição da escola enquanto cultura.

Segundo Durozoi e Roussel (1993, p. 115), o termo cultura tornou-se praticamente sinônimo de civilização, e designa “o conjunto das tradições, técnicas e instituições que caracterizam um grupo humano: a cultura compreendida dessa maneira é normativa e adquirida pelo indivíduo, desde a infância, pelos processos de aculturação ${ }^{4 \prime}$. Até mesmo comportamentos aparentemente naturais, como a alimentação, variam de acordo com a cultura a que o indivíduo pertence.

Visando selecionar algumas definições clássicas do conceito de cultura do ponto de vista antropológico, recorre-se aqui a algumas definições dadas ao termo coligidas na enciclopédia Mirador (1987).

\footnotetext{
4 Em Psicologia social, o termo aculturação, de acordo com o dicionário Aurélio, refere-se à "adaptação de um indivíduo a uma nova cultura com que estabelece contato, seja em seu local de origem, seja em outro local para que se tenha mudado". Para referir-se ao "processo de condicionamento e/ou de aprendizagem, consciente ou inconsciente, formal ou informal, mediante o qual um indivíduo, no decorrer da vida, apreende os padrões gerais de sua cultura", de acordo com o mesmo dicionário, o termo mais adequado seria enculturação, que equivale à socialização.
} 
Segundo Franz Boas (1987, p. 3109 a 3131),

cultura é a totalidade das reações e atividades mentais e físicas que caracterizam a conduta dos indivíduos componentes de um grupo social, coletiva e individualmente, em relação ao seu meio natural, a outros membros do grupo, e de cada indivíduo em relação a si mesmo.

Para Malinowski (1987, p. 3109), “cultura é um todo indivisível, onde penetram as instituições, que por um lado são autônomas e de outra parte se comunicam". Radcliffe-Brown (1987, p. 3109) afirma que a existência de cultura diferencia a vida social dos grupos humanos dos animais: "a transmissão de maneiras de pensar, sentir e agir que constitui o processo cultural [...] nada mais é do que uma parte do processo total de interação entre pessoas." Para Lévi-Strauss (1987, p. 3109), cultura é, antes de tudo, "um universo de regras, cuja existência ou ausência representa o critério mais seguro que permite distinguir um processo natural de um processo cultural".

Cultura é aquilo que dá significado às ações realizadas pelo ser humano em uma sociedade. Segundo Hall (1997, s/p), que postula a questão da centralidade da cultura e sua função constitutiva nos mais diversos aspectos da vida social,

a ação social é significativa tanto para aqueles que a praticam quanto para os que a observam: não em si mesma mas em razão dos muitos e variados sistemas de significado que os seres humanos utilizam para definir o que significam as coisas e para codificar, organizar e regular sua conduta uns em relação aos outros. Estes sistemas ou códigos de significado dão sentido às nossas ações. Eles nos permitem interpretar significativamente as ações alheias. Tomados em seu conjunto, eles constituem nossas "culturas".

Para esse autor, é pouco significativa a linha que separa a definição do conceito de cultura do ponto de vista social da definição do ponto 
de vista psicológico, uma vez que afirma a importância da cultura na constituição da subjetividade. Hall (1997) considera que a cultura tem um papel regulador nas mudanças sociais, que pode se dar de forma normativa, classificatória ou na constituição de novos sujeitos e produção de novas subjetividades.

Brandão (1983, p.14) define de forma significativa como a cultura de uma sociedade se relaciona com a educação:

o homem que transforma, com o trabalho e a consciência, partes da natureza em invenções de sua cultura, aprendeu com o tempo a transformar partes das trocas feitas no interior desta cultura em situações sociais de aprender-ensinar-e-aprender: em educação.

Para este autor, o processo de socialização de um indivíduo dentro da cultura na qual nasce é um processo de ensino e de aprendizagem que ocorre de forma implícita, sendo muito anterior ao surgimento do ensino formal. Brandão (1983) defende que, à medida que as organizações sociais tornam-se mais complexas, inclusive impondo a necessidade da divisão de trabalho, as formas e processos envolvidos de transmissão do saber começam a ser vistas como um problema a ser pensado, $\mathrm{o}$ que dá origem à educação formal.

O conceito de cultura é tomado emprestado da antropologia pela teoria das organizações para iluminar o conceito de cultura organizacional, de forma a diferenciá-lo do conceito de estrutura organizacional (Nóvoa, 1995, p. 28). Nessa perspectiva, a escola como organização social é passível de ser compreendida como possuindo uma cultura própria, na qual o pesquisador focaliza sua atenção com a finalidade de compreender o ato educativo em relação a esse contexto.

Outro conceito que aparece vinculado à escola como organização possuidora de determinada cultura é o conceito de clima 
organizacional da escola. Brito (1997, p. 209) detalha o conceito de clima da escola como "uma série de atributos característicos de determinada instituição, que induzem a escola a agir consciente ou inconscientemente de determinada maneira de acordo com seus membros e com a sociedade na qual está inserida".

Segundo esse autor, a forma como os indivíduos percebem a realidade social e da escola, e com elas se relacionam, acaba por dar ao clima da escola uma natureza intersubjetiva.

Para Brunet (1995, p. 138), o clima organizacional da escola pode ser qualificado como fechado ou aberto, de acordo com a maior ou menor rigidez e com o grau de participação dos indivíduos que a organização permite, e sendo percebido por esses participantes de forma mais ou menos consciente. Cada escola teria uma "personalidade própria, que a caracteriza e que formaliza os comportamentos dos seus membros".

Libâneo (2001, p. 9) define a cultura da escola como o “conjunto de fatores sociais, culturais, psicológicos que influenciam os modos de agir da organização como um todo e do comportamento das pessoas em particular". Portanto, além dos aspectos procedimentais e administrativos da organização escolar, também haveriam aspectos de natureza cultural, geralmente implícitos, que caracterizariam as escolas de forma diferenciada. Tais aspectos, para o autor, constituem o que se conhece por currículo oculto, ou seja, diretrizes que, ainda que tacitamente, atuam de forma importante na forma como a escola funciona e nas práticas dos seus profissionais. Libâneo (2001, p. 144-145) define currículo oculto como

influências que afetam a aprendizagem dos alunos e o trabalho dos professores provenientes da experiência cultural, dos valores e significados trazidos pelas pessoas de seu meio social e vivenciados na própria escola, ou seja, das práticas e experiências compartilhadas na escola e na sala de aula. O currículo oculto representa tudo o que os alunos aprendem pela convivência espontânea em meio às várias 
práticas, atitudes, comportamentos, gestos, percepções, que vigoram no meio social e escolar. O currículo está "oculto" porque ele não é prescrito, não aparece no planejamento, embora se constitua como importante fator de aprendizagem.

A idéia de cultura da escola deriva-se do conceito sociológico de cultura (FORQUIN, 1993 apud LIBÂNEO, 2001). Nesse conceito, consideram-se as diferentes características culturais de alunos e de professores, mas enfatiza-se, principalmente, que as práticas características de uma escola estariam impregnadas dessa cultura peculiar, que afeta tanto professores quanto alunos e teria características de vida próprias.

Assim, pode-se dizer que o modo como a escola se organiza e funciona, incluindo as relações que nele se estabelecem, é uma cultura:

a partir da interação entre diretores, coordenadores pedagógicos e professores, funcionários, alunos, a escola vai adquirindo, na vivência do dia-a-dia, traços culturais próprios, vai formando crenças, valores, significados, modos de agir, práticas. É o que estamos denominando de cultura da escola ou cultura organizacional. Essa cultura própria vai sendo internalizada pelas pessoas e vai gerando um estilo coletivo de perceber as coisas, de pensar os problemas, de encontrar soluções. É claro que isso não se dá sem conflitos, diferenças, discordâncias, podendo haver até quem destoe dessa cultura. Mas há em cada escola uma forma dominante de ação e interação entre as pessoas que poderia ser resumida nesta expressão: "temos a nossa maneira de fazer as coisas por aqui" (LIBÂNEO, 2001, p. 85).

Teixeira e Porto (1997, p. 219) afirmam que, ainda que as escolas tenham organizações estruturais semelhantes, elas divergem pelas diferentes maneiras com que se apropriam do saber e da cultura de uma sociedade, podendo-se falar de culturas escolares diversas, a despeito das intenções homogenizadoras das orientações dos sistemas para a gestão escolar, 
que, "em razão da diversidade sócio-cultural das escolas, são reinterpretados, relativizados, e adaptados às condições concretas de cada qual".

Para Nóvoa (1995, p. 15), centrar o olhar na escola, buscando apreender como a mesma se organiza e se institui, não significa excluir a relação desta organização com o círculo social maior, mas contextualizá-la a fim de apreender os significados do ato educativo. Segundo o autor,

a emergência recente de uma sociologia das organizações escolares,
situada entre uma abordagem centrada na sala de aula e as
perspectivas sócio-institucionais focalizadas no sistema educativo, é
uma das realidades mais interessantes da nova investigação em
Ciências da Educação. Trata-se de procurar escapar ao vaivém
tradicional entre uma percepção micro e um olhar macro,
privilegiando um nível mesmo de compreensão e de intervenção. As
instituições escolares adquirem uma dimensão própria, enquanto
espaço organizacional onde também se tomam importantes decisões
educativas, curriculares e pedagógicas.

A cultura que caracteriza as sociedades humanas, de acordo com Gusmão (2003), é dinâmica e se expande constantemente. O desafio que se impõe à escola é compreender a cultura de que os indivíduos fazem parte. A escola, além de espaço de socialização, é um espaço sócio-cultural, de encontros e desencontros, e da convivência com a diversidade.

O conceito de escola como espaço sociocultural é desenvolvido por Dayrell (1997, p. 137):

analisar a escola como espaço sociocultural significa compreendê-la na ótica da cultura, sob um olhar mais denso, que leva em conta a dimensão do dinamismo, do fazer-se cotidiano, levado a efeito por homens e mulheres, trabalhadores e trabalhadoras, negros e brancos, adultos e adolescentes, enfim, alunos e professores, seres humanos concretos, sujeitos sociais e históricos, presentes na história, atores na 
história. Falar da escola como espaço sociocultural implica, assim, resgatar o papel dos sujeitos na trama social que a constitui, enquanto instituição.

Capelo (2003, p. 108), explorando a etimologia da palavra cultura, postula que esta tem o significado de conhecimento compartilhado, bem como de instrumento mediador entre o ser humano e o ambiente em que vive. Segundo ele, "os grupos sociais constituem muitas formas de simbolizar, de modo que faz sentido falar em muitas e diferentes culturas". O autor faz ainda algumas reflexões importantes no sentido da dificuldade da escola olhar o aluno enquanto ser sócio-histórico, bem como o tradicional esforço da escola no sentido de uniformizar as necessidades de seus alunos, que terminaria por reforçar a desigualdade e a injustiça social:

A diversidade aparece na escola formal de vários modos. Os alunos (crianças, adolescentes, adultos) são procedentes de famílias diferentes, possuem biografias, raízes étnicas e culturais, religiosidades, experiências de vida, valores, visões de mundo, temporalidades, espacialidades, saberes e fazeres que diferem entre si. Eles carregam as marcas (no mais das vezes, invisíveis) de suas origens e pertencimentos, mas isso não é levado em conta na definição dos conteúdos porque a escola se incumbe de hierarquizar novamente o que já se apresenta como desigual, assim como cuida de homogeneizar o que é heterogêneo (p. 116-117).

Questionar certos aspectos hegemônicos da cultura escolar parece fundamental quando se procura construir uma educação voltada para o respeito e a valorização da diversidade. Esta orientação de considerar as diferenças é muitas vezes o contrário do que a escola tradicional busca, tentando homogeneizar os alunos e escamotear as desigualdades sociais.

A unicidade de cada ser humano historicamente construído por múltiplas determinações torna-se presente, segundo Silva Jr e Ferretti (2004), nas organizações das quais participa. Assim, "na escola os 
conflitos e contradições podem ser analisados e eventualmente explicados a partir das relações que se estabelecem no âmbito da cultura institucional" (p. 57). Em sua análise, os autores postulam que a forma como a escola não divulga simplesmente o conhecimento acumulado pela humanidade, mas sim o recorte que faz dele, contextualizado social e historicamente:

Concretamente, a escola resulta do amálgama entre sua dimensão institucional e sua cultura específica, historicamente construída. Este amálgama se produz e se faz presente nas práticas escolares, elemento central por meio do qual a instituição escolar realiza os processos de formação social do indivíduo e socializa o conhecimento produzido pela humanidade, ao mesmo tempo em que se reproduz socialmente (p. 59-60).

Não pode haver uma escola ideal que dê conta da diversidade a partir de seus conteúdos curriculares sem que se discuta a diversidade cultural do país e do sistema educacional, segundo Demartini (2003). Assim, a discussão foca-se numa escola genérica, e perde-se de vista a concretude da cultura em que a escola se insere.

A esse respeito, Libâneo (2001, p. 86-87) faz uma contribuição importante, ao defender que

na perspectiva sócio-crítica da cultura organizacional, considera-se que na escola ocorre uma disputa de interesses sociais e individuais, em que a equipe escolar discute a realidade, os significados, os valores, as diferenças, as relações de poder externas e internas, para se chegar a definições e decisões em torno dos objetivos comuns. Considera, também, que a escola se insere num contexto sociocultural e político mais amplo, cuja influência na organização escolar é determinante. Uma concepção realista da organização escolar considera, ao mesmo tempo, os valores, os significados, as interpretações das pessoas em relação ao que precisa ser feito, mas também considera os objetivos e os propósitos sociais da organização 
escolar, dentro da realidade sociocultural e política mais ampla, que requerem uma ação organizada, racional, uma normatividade.

Sá e Rahme (2001, p. 90) defendem que a escola, visando ampliar sua função socializadora, precisa incorporar a diversidade que caracteriza o ser humano:

é necessário abrir-se ao desafio da mudança e da descoberta, dialogando com um inesgotável repertório de comportamentos, demandas posturas, hábitos e atitudes. Deve estimular a curiosidade, as expressões de talento e a criatividade exercitando-as, reconhecendo múltiplas linguagens e estilos. Para que isto aconteça, não pode manter-se como reduto isolado; precisa se abrir para o mundo à sua volta, participando dos movimentos sociais e do mosaico de experiências em constante mutação no dinâmico e complexo fluxo da vida contemporânea.

O currículo escolar, para Libâneo, é um componente importante da cultura de uma escola, uma vez que é construído sobre representações sociais de uma cultura, que garantiriam a continuidade dos valores de uma sociedade. O autor afirma ainda que "o currículo é a concretização do posicionamento da escola face à cultura produzida pela sociedade. Existe ensino porque existe uma cultura, e o currículo é a seleção e organização dessa cultura" (LIBÂNEO, 2001, p. 142). O currículo articula, portanto, a cultura social e a prática pedagógica, refletindo a seleção realizada pela equipe escolar e professores a partir dos conteúdos socialmente validados e considerados importantes, que buscam oferecer, com esta escolha, o que acreditam que seus alunos precisam aprender, bem como expressar que tipo de ser humano pretendem formar.

Segundo Miranda (2004, p. 128), a escola atua como socializadora numa sociedade pretensamente democrática. Desta forma, 
não existe, portanto, uma natureza infantil, mas uma condição de ser criança, socialmente determinada por fatores que vão do biológico ao social, produzindo uma realidade concreta. Assim, a dependência da criança é um fato social e não um fato natural.

Reportando-se a Charlot, Miranda (2004, p. 131) afirma que "o problema não é investigar como a criança se socializa, mas 'como a sociedade socializa a criança". Por estes processos de socialização vividos na escola, a criança irá internalizar valores e comportamentos da cultura à qual pertence, sendo fundamental repensar as formas como esse processo se dá, e os atores através dos quais se concretiza na escola. Na escola enquanto instituição voltada para atender à diversidade, o currículo deve refletir este objetivo.

Pérez Gómez (1998, p. 54) faz referência à teoria vigotskiana para pontuar que

o desenvolvimento filogenético e ontogenético do ser humano está mediado pela cultura e somente a impregnação social e cultural do psiquismo provocou a diferenciação humana ao longo da história. A humanidade é o que é porque cria, assimila e reconstrói a cultura formada por elementos materiais e simbólicos. Do mesmo modo, o desenvolvimento da criança se encontra inevitavelmente vinculado à sua incorporação mais ou menos criativa para a cultura de sua comunidade.

A cultura, segundo Pérez Gómez (1998), é uma instância mediadora entre as pessoas e o mundo em que vivem, bem como entre as pessoas e elas mesmas, possuindo tanto a função de determinante quanto produto das relações humanas.

O ambiente escolar envolve várias dimensões além das cognitiva e comportamental, habitualmente mais valorizadas, o que acaba por desconsiderar a totalidade das dimensões humanas dos sujeitos envolvidos no ato educativo (DAYRELL, 1997, p. 139). 
Para Forquin (1993 apud DAYRELL, 1997, p. 150), a escola tem vida própria e isto se expressa em sua cultura peculiar. Assim como a cultura é dinâmica, a escola também o é, e isto pode ser efetivamente percebido na forma como os participantes de uma dada escola se apropriam desta cultura e a reelaboram em seu cotidiano. Assim, paralelamente aos objetivos educacionais explícitos da escola, ocorrem uma variedade de experiências cujo potencial educativo pode ser aproveitado. Forquin adverte ainda que é importante considerar a dimensão cotidiana da escola, uma vez que esta

pode e deve ser um espaço de formação ampla do aluno, que aprofunde o seu processo de humanização, aprimorando as dimensões e habilidades que fazem de cada um de nós seres humanos. $\mathrm{O}$ acesso ao conhecimento, às relações sociais, às experiências culturalmente diversas podem contribuir assim como suporte no desenvolvimento singular do aluno como sujeito sociocultural, e no aprimoramento de sua vida social. (p. 159-160).

Uma síntese interessante das idéias até aqui apresentadas pode ser feita através da afirmação de Gadotti (2001, p. 57), no "Decálogo da escola cidadã", onde adverte que "não há duas escolas iguais. Cada escola é fruto do desenvolvimento das suas contradições".

Até aqui, percorreu-se diversas definições de cultura para chegar à definição de cultura escolar, onde a escola é entendida como tendo uma cultura própria, que permeia a prática dos seus profissionais e alunos, bem como pode ser traduzida em suas ações. A escola também foi discutida como instituição social fundamental de participação em uma sociedade. Na seqüência, discutiremos a participação do indivíduo na escola como chave da participação em uma dada sociedade humana, portanto, de humanização. 


\subsection{Estar na escola como condição de humanização}

Da análise realizada até aqui, depreende-se a importância que o processo de escolarização exerce na vida da criança, por ser a escola o espaço de educação mais reconhecido na sociedade atual, lugar onde se recria um conhecimento específico, o que o diferencia da educação informal ou familiar. À criança com deficiência, ao ser excluída da escola estaria, portanto, sendo negado o direito a esta forma de aquisição cultural específica e fundamental em uma sociedade como a nossa, em que a educação escolar é altamente valorizada. Daí conclui-se a gravidade da exclusão de um aluno do sistema educacional. De acordo com Rego (2002, p. 48), “o fato de o indivíduo não ter acesso à escola significa um impedimento da apropriação do saber sistematizado, de instrumentos de atuação no meio social e de condições para a construção de novos conhecimento". A autora destaca o importante papel que a escola exerce na aquisição de conhecimentos de forma sistematizada, lembrando a ênfase dada por Vigotski a esta dimensão do trabalho escolar na formação de conceitos e ao desenvolvimento das funções psicológicas superiores. Rego (2002, p. 51) ressalta ainda que

as atividades educativas na instituição escolar, diversamente do que ocorre no cotidiano extra-escolar, são sistemáticas, têm uma intencionalidade deliberada e um compromisso explícito (legitimado historicamente) em tornar acessível o conhecimento formalmente organizado. Em tal contexto, os estudantes são desafiados a entender as bases dos sistemas de concepções científicas, a realizar abstrações e generalizações mais amplas acerca da realidade (que, por sua vez, transformam os modos de utilização da linguagem) e a tomar consciência de seus próprios processos mentais (metacognição). A interação com esses conhecimentos possibilita ao sujeito novas formas de pensamento, de inserção e atuação em seu meio: à medida que expande seus conhecimentos, o indivíduo modifica sua relação cognitiva com o mundo. 
Duarte (2000, p. 83) cita a concepção de Vigotski sobre o desenvolvimento do indivíduo a partir da apropriação pelo mesmo dos produtos da cultura em que vive, mediatizado pelos adultos que já passaram por este processo, como sendo a "principal força impulsionadora de todo o desenvolvimento". Para este autor, "a transmissão pelo adulto à criança, da cultura construída na história social humana, não é concebida na psicologia vigotskiana apenas como um dos fatores do desenvolvimento, ela é considerada o fator determinante, principal". Considerando-se a participação da criança na escola, onde a mesma tem o oferecimento de oportunidades sistemáticas de desenvolvimento, reafirmam-se mais uma vez as possibilidades que se descortinam com escolarização.

A partir destes aportes teóricos, pode-se afirmar que estar na escola é uma condição de humanização. A condição de incompletude em que o ser humano nasce aponta para a importância crucial de pertencer a uma cultura humana, que é sua condição de sobrevivência. Ser cuidado, inserido na cultura, faz com que o ser humano viva e complete seu desenvolvimento. Não há outra forma de sobreviver a não ser participando de uma cultura (CHARLOT, 2000, p. 53):

A prematuração do homem é apenas uma face da condição humana, inseparável de sua outra face: o homem sobrevive por nascer em um mundo humano, pré-existente, que já é estruturado. [...] Mas, por sua condição também, o homem é uma presença fora de si. Está presente nesse outro que, muito concretamente, lhe permite sobreviver e que também é um homem. Esse outro, por ser a figura do humano, é objeto de desejo, em formas complexas. E objeto de amor, pois ele é aquilo que eu preciso; e, indissociavelmente, objeto de ódio, pois sua existência em si mesma atesta que eu não resumo a totalidade do humano. Mas o homem está presente também sob a forma de um mundo, um mundo humano produzido pela espécie ao longo de sua história e que existe antes da criança, sob a forma de estruturas, ferramentas, relações, palavras e conceitos, obras. Essa ausência de si 
mesmo/presença em si fora de si mesmo é a própria condição do homem.

Para Charlot (2000, p. 53), a mediação do humano e da cultura faz nascer o indivíduo humano. "A educação é produção de si por si mesmo; é o processo através do qual a criança que nasce inacabada se constrói enquanto ser humano, social e singular". Este autor ressalta ainda que "não há sujeito senão em um mundo e em uma relação com o outro. [...] A relação com o saber não deixa de ser uma relação social, embora sendo de um sujeito" (p. 73).

Estar na escola é, pois, fundamental em nossa sociedade. De acordo com Saviani (2003, p. 103),

já não é possível compreender a educação sem a escola, porque a escola é a forma dominante e principal de educação. Assim, para compreender-se as diferentes modalidades de educação, exige-se a compreensão da escola. Em contrapartida, a escola pode ser compreendida independentemente das demais modalidades de educação.

Vigotski (2003, p. 200) enfatiza de forma recorrente a importância do ambiente social no desenvolvimento de possibilidades educacionais para a criança:

Fica claro, portanto, que uma educação ideal só é possível com base em um ambiente social orientado de modo adequado e que os problemas essenciais da educação só podem ser resolvidos depois de solucionada a questão social em toda a sua plenitude. Daí deriva também a conclusão de que o material humano possui uma infinita plasticidade se o meio social estiver organizado de forma correta. Tudo pode ser educado e reeducado no ser humano por meio da influência social correspondente. A própria personalidade não deve ser entendida como uma forma acabada, mas como uma forma dinâmica de interação que flui permanentemente entre o organismo e o meio. 
Escola, como vem sendo debatido aqui, refere-se à escola onde é oferecido ensino regular, não incluindo aí a escola especial que tenha como objetivo o atendimento segregado para pessoas com deficiência. É importante fazer esta distinção, pois o que está sendo discutido é o acesso de qualquer criança à escola regular e pública como espaço social constituído, e não à escola criada de forma a atender supostas especificidades decorrentes de uma deficiência. É a escola regular que está aqui sendo focalizada pelos autores citados como instituição de uma determinada sociedade, e é nesta escola que o ingresso da criança com deficiência está sendo entendido como fundamental para sua humanização.

Vigotski (2003, p. 262) faz algumas importantes considerações sobre a educação segregada em escolas especiais, ainda que admita a sua eficácia nos casos mais graves de deficiência mental. Para o autor, não há uma diferença significativa nos métodos de ensino para crianças normais e com deficiência, o que é coerente com sua visão do desenvolvimento humano em interação com o ambiente social: "do ponto de vista psicológico, é sumamente importante não isolar essas crianças em grupos fechados especiais, mas exercitar o mais amplamente possível sua comunicação com os demais". As maiores dificuldades são atribuídas aos aspectos práticos da organização escolar e pedagógica, uma vez que os benefícios para os alunos parecem evidentes:

Nesse caso, as considerações pedagógicas práticas sobre a utilidade da educação às vezes entram em contradição com as exigências psicológicas. [...] Alguns pedagogos supõem que a separação das crianças deficientes em escolas especiais nem sempre é útil - ainda que, do ponto de vista do cumprimento do programa, seja desejável "aliviar" as escolas comuns dessas crianças (p. 262-263)

Mesmo para as crianças com questões mais graves do ponto de vista psiquiátrico e neurológico, os benefícios de um ambiente 
adaptado ao distúrbio da criança são evidentes. Vigotski (2003, p. 262-263) alerta que, obviamente, isso não quer dizer que ajustes ambientais possam converter qualquer comportamento anormal em normal, mas é a atitude mais pertinente em face dos conhecimentos atualmente disponíveis sobre estas patologias:

Consideramos que não conhecemos nem uma centésima parte das possibilidades da educação social e, embora não se possa falar da completa superação de todos os defeitos, temos bases concretas para afirmar que, sem essa educação, nenhuma outra está em condições de conceder formas socialmente úteis a esse comportamento anormal.

Tomando a teoria sócio-histórica como pano de fundo, e de posse dos conceitos discutidos sobre a escola como cultura, é interessante destacar o que Evans (1995, p. 83) fala sobre a experiência inglesa, ressaltando que as escolas especiais representam microculturas educacionais que se desenvolveram de forma independente e freqüentemente isoladas, diferindo tanto entre das escolas regulares como de outras escolas especiais. Baseado em pesquisas, afirma que "há alguma evidência de que culturas escolares diferentes realmente têm um impacto diferenciado na cognição dos alunos", razão pela qual é importante refletir-se sobre as formas como a aprendizagem se estrutura nestas escolas, com a finalidade de evitar grandes discrepâncias com os padrões escolares vigentes, o que dificultaria uma integração futura na sociedade, bem como a transição de uma escola especial para uma escola regular, num processo de inclusão. Ainda utilizando o conceito da escola como uma microcultura, Evans (1995, p. 84) alerta para a probabilidade de que "as crianças educadas em escolas especiais desenvolvam uma forma de pensar culturalmente diferente da de crianças educadas em escolas regulares, onde métodos e currículos são mais homogêneos". O autor afirma, ainda, que o mesmo argumento pode ser usado para os alunos de escolas regulares que não têm contato com alunos com deficiência, dificultando sua elaboração de como 
lidar com as diferenças, o que aponta para um benefício da inclusão para as crianças ditas normais.

Kassar (1995, p. 26) alerta para os perigos de se enfocar a educação especial como separada da Educação, o que acaba produzindo uma descontextualização da produção nessa área da Educação de forma geral. Disso resulta que o "excesso de especificidade em educação especial faz veicular a idéia da não-pertinência dos problemas 'especiais' para o ensino regular". Dessa forma, os trabalhos em Educação que falam por exemplo em evasão e repetência desconsideram a educação especial, e esta não analisa sua clientela sob o enfoque da exclusão: "o especial e o comum são vistos como dois problemas distintos" (KASSAR, 1995, p. 27, grifos da autora).

Depreende-se daí a idéia de que a escola, na sociedade ocidental contemporânea, é uma das formas mais importantes do indivíduo humano pertencer à sua cultura, uma vez que a escolarização é muito valorizada nesta sociedade. Além disso, na escola o indivíduo entra em contato com formas sistematizadas de transmissão de conhecimento e relações entre pessoas de um tipo específico, não vivenciado fora dela. Daí o papel fundamental que a escolarização exerce na socialização humana, o que justifica e corrobora o acesso universal à escola.

\subsection{Vigotski e a defectologia}

O objetivo de apresentar resumidamente algumas das idéias deste autor é aprofundar os conceitos por ele explorados em relação ao papel fundamental do contexto social no desenvolvimento da criança com deficiência, e portanto iluminar a importância da escolarização para estas crianças, bem como continuar a investigar a escola como uma cultura que 
atuará na mediação entre a criança com deficiência e a sociedade na qual esta escola se insere.

Em relação à produção de Vigotski em educação especial, é essencial ressaltar o importante papel que este autor exerceu trabalhando com a educação especial na União Soviética, tendo escrito vários artigos sobre o assunto, sendo que os primeiros trabalhos foram publicados em 1924, período em que atuou em setor voltado à educação de crianças com deficiência em Moscou (na então União das Repúblicas Socialistas Soviéticas). Nesta cidade, organizou um laboratório de pesquisa sobre desenvolvimento anormal da infância, que deu origem ao Instituto Defectológico Experimental em 1929, onde exerceu o cargo de diretor até vir a falecer no ano de 1934, contando então 38 anos de vida. Seus trabalhos mais importantes na área foram coligidos no volume cinco da edição espanhola das Obras Escogidas chamado "Fundamentos de defectología", tomado como referência neste trabalho. Os termos utilizados neste resumo foram derivados da escrita do autor, historicamente construída e, portanto, podem parecer um tanto desatualizados face às terminologias atuais utilizadas na referência aos indivíduos com deficiência. Optou-se por mantê-los assim, utilizando no entanto "criança com deficiência" para traduzir a expressão "niño deficiente".

O termo defectologia foi definido por Vigotski, a partir da teoria materialista dialética sobre o desenvolvimento, como o campo do saber acerca da variedade qualitativa do desenvolvimento de crianças anormais e a diversidade de tipos deste desenvolvimento. Na seqüência, apresentaremos alguns textos do autor destacados da obra supra-citada, de forma a resumir suas principais idéias sobre a temática aqui discutida.

Vigotski, no texto de 1929 intitulado "Os problemas fundamentais da defectologia contemporânea", esboça sobre esta base os principais objetivos teóricos e práticos que enfrentam a defectologia e a escola 
especial soviética, criticando o até então enfoque quantitativo dado ao estudo das deficiências, resultado de uma visão maturacionista do ser humano, que desconsidera o ambiente social e a constituição diferenciada, a partir da sua deficiência, que a pessoa atinge em interação com este ambiente: "a especificidade da estrutura orgânica e psicológica, o tipo de desenvolvimento e de personalidade, e não as proporções quantitativas distinguem a criança deficiente mental da normal" (Vygotski, 1929, p. 12, tradução nossa). Vigotski afirma que o objeto de estudo próprio da defectologia são os processos do desenvolvimento infantil em sua diversidade de formas, devendo buscar explicá-lo e procurar as leis comuns que o dirigem.

Para o autor, a deficiência orgânica tem um papel duplo no desenvolvimento e na formação da personalidade da criança, pois se, por um lado, é uma limitação, por outro, justamente por isso, estimula um avanço intenso. Sua tese central é a de que toda deficiência cria os estímulos para uma compensação. Desta forma, deve-se examinar o indivíduo com deficiência e não a deficiência de forma isolada a fim de compreender como este processo de compensação ocorre.

Vigotski (1929) afirma que os processos que criam as particularidades da personalidade não fluem livremente, mas se orientam para fins específicos, num condicionamento socialmente determinado. Dois fatores contribuem para isso. O primeiro é que a ação da deficiência é sempre secundária, e não direta, uma vez que a criança com deficiência não a sente diretamente, e sim as dificuldades que derivam da deficiência e suas conseqüências sociais, influenciando na reestruturação dos vínculos com as pessoas e suas consequiências sociais. A deficiência que conduz à compensação criaria uma posição psicológica particular para a criança, através da qual (e somente através dela) a deficiência interfere no desenvolvimento da criança. $O$ segundo aspecto seria a orientação social da compensação para adaptar-se às condições oferecidas pelo ambiente, que foi criado para um ser humano não- 
deficiente. Assim, uma criança com deficiência não é necessariamente uma criança deficiente. O grau de sua deficiência e normalidade dependem do resultado da compensação social, ou seja, da formação final de sua personalidade. Tomando-se como exemplo a deficiência mental, observa-se que esta pode ocorrer das mais variadas formas, dada a complexidade com que o intelecto se estrutura no ser humano e das formas diferenciadas como esse percebe as relações, admitindo, portanto, uma ampla compensação das diversas funções intelectuais.

Para Vigotski (1929), o desenvolvimento cultural da criança com deficiência era um problema bastante complexo. Em uma criança com desenvolvimento normal, geralmente coincidem sua crescente participação na cultura em que nasce com seu desenvolvimento orgânico. “Ambas as séries de modificações convergem, se interpenetram mutuamente e constituem, em essência, a série única da formação sociobiológica da personalidade. Na medida em que o desenvolvimento orgânico se realiza num meio cultural, vai se transformando num processo biológico historicamente condicionado" (Vygotski, 1929, p. 26, tradução nossa). Esta fusão não se observa na criança com deficiência, cujos planos do desenvolvimento parecem divergir em maior ou menor grau. Esta divergência deve-se à deficiência orgânica, pois a cultura da humanidade foi criada em certas condições de estabilidade e constância do tipo biológico humano.

Assim, tanto suas ferramentas materiais quanto seus aparatos sócio-psicológicos estão calculados para uma organização psicofisiológica normal. A utilização destes instrumentos e aparatos pressupõe a existência do intelecto, órgãos e funções próprias do homem. Para Vigotski, a deficiência, ao criar um desvio do tipo humano biológico estável do homem, provocando a reestruturação mais ou menos substancial de todo o desenvolvimento sobre novas bases, atrapalha o processo normal de inserção da criança na cultura, já que esta está adaptada a uma pessoa normal, e o 
desenvolvimento atípico condicionado pela deficiência não pode enraizar-se direta e imediatamente na cultura, como ocorre com a criança normal (Vigotsky, 1929, p. 27). Desta forma, freqüentemente são necessárias formas culturais peculiares, para que se realize o desenvolvimento cultural da criança com deficiência (recursos adaptados como o alfabeto braile, a linguagem de sinais, etc).

O problema do desenvolvimento cultural da criança com deficiência é colocado, portanto, como um plano especial de desenvolvimento, subordinado a leis especiais e que tem dificuldades e meios especiais para superá-las. “A incapacidade de empregar as funções psicológicas naturais e de dominar as ferramentas psicológicas determina essencialmente o tipo de desenvolvimento cultural de uma criança com deficiência" (VYGOTSKI, 1929, p. 30, grifo do autor, tradução nossa). A capacidade de simbolização que o desenvolvimento da linguagem implica (cada coisa tem um nome, a palavra é um signo), não pode ser atingida plenamente por um indivíduo com deficiência mental, impedindo o desenvolvimento da atividade intelectual superior.

O autor defende que os métodos da educação especial não devem se limitar a um programa reduzido e simplificado em relação ao currículo normal, mas buscar formas de trabalho apropriadas às especificidades de seus educandos. Em relação à questão do diagnóstico, aponta que é importante estabelecer as diferenças quantitativas da criança com deficiência, mas que não se deve deter neste aspecto, principalmente em relação aos aspectos negativos, pois pouco se sabia (e ainda se sabe) sobre as possibilidades positivas da criança com deficiência.

A partir de seus apontamentos sobre a questão da educação da criança com deficiência, Vigotski (1929) tece considerações sobre a função da escola especial, que a meu ver podem ser mais bem colocadas em 
relação à educação especial de forma geral ${ }^{5}$. Em relação à escola especial, o autor lembra que seria equivocado desconsiderar que os limites da particularidade da escola especial estão nos fins comuns e tarefas sociais compartilhados com a escola regular. A escola especial não serve para criar uma espécie particular de seres humanos, mas cidadãos participantes, sendo, portanto, seu maior desafio chegar a esse objetivo comum a todos os membros de uma sociedade através de meios peculiares próprios da educação especial. Seu objetivo é aproximar da melhor forma a criança com deficiência do normal (normalização).

O autor alerta ainda que, do ponto de vista psicológico, é incorreto negar a capacidade criativa da criança com deficiência mental. Dominar as quatro operações é um processo muito mais criativo para uma criança com deficiência mental do que para uma criança sem esta limitação. Para Vigotski (1929), a criança com deficiência possui uma vida psíquica normal que está além da deficiência e precisamente por ter dificuldade em desenvolver o pensamento abstrato é que se deve trabalhar estes processos com a criança. $\mathrm{O}$ autor defende que a escola não deve somente adaptar-se às insuficiências do aluno, mas lutar contra elas e buscar superá-las.

No texto "Acerca dos processos compensatórios no desenvolvimento da criança mentalmente atrasada", Vigotski (1931a) comenta a tendência de aproximação da escola especial para a escola comum:

\footnotetext{
5 Cabe fazer aqui a distinção entre educação especial e escola especial. De acordo com a Resolução CNE/CEB Nº 2, de 2001, que institui Diretrizes Nacionais para a educação especial na educação básica, em seu artigo $3^{\circ}$, "por educação especial, modalidade da educação escolar, entende-se um processo educacional definido por uma proposta pedagógica que assegure recursos e serviços educacionais especiais, organizados institucionalmente para apoiar, complementar, suplementar e, em alguns casos, substituir os serviços educacionais comuns, de modo a garantir a educação escolar e promover o desenvolvimento das potencialidades dos educandos que apresentam necessidades educacionais especiais, em todas as etapas e modalidades da educação básica". Já escola especial, de acordo com o artigo 10 da mesma resolução, é aquela voltada para alunos cujas necessidades seriam de tal forma específica que a escola comum não consiga provê-las, advertindo, contudo, que esta permanência deve ser sempre avaliada com vista à transferência do aluno, sempre que possível, para uma escola comum. A educação especial, portanto, é uma modalidade de ensino, e pode ser oferecida nos diferentes níveis de ensino (educação básica e superior) de forma transversal.
} 
ainda que as crianças mentalmente atrasadas estudem mais prolongadamente, ainda que aprendam menos que as crianças normais, e ainda que, por fim, se lhes ensine de outro modo, aplicando métodos e procedimentos especiais, adaptados às características específicas de seu estado, devem estudar o mesmo que as demais crianças, receber a mesma preparação para a vida futura, para que depois participem dela, em certa medida, como os demais (Vygotski, 1931a, p. 149, tradução nossa).

Em relação à importância da participação da criança em agrupamentos escolares, é interessante percorrer algumas idéias discutidas por Vigotski no texto "A coletividade como fator de desenvolvimento da criança deficiente" (1931b). Neste texto, Vigotski inicia dizendo que as leis que regulam o desenvolvimento tanto da criança normal quanto da anormal (sic) são fundamentalmente as mesmas, sendo esse fato fundamental para o estudo comparativo da criança. Em cada caso, contudo, estas regularidades terão uma expressão específica, sendo importante, no estudo comparativo, manter o duplo objetivo de estabelecer as regularidades comuns e descobrir sua manifestação específica nas diferentes variações do desenvolvimento infantil.

O problema que interessa ao autor é a coletividade como fator de desenvolvimento da criança com deficiência. Como coletividade, o autor entende a unificação em um grupo comum de acordo com algum critério, que pode ser idade, tipo de deficiência ou nível de desenvolvimento, com um programa de ensino comum. A orientação de um objetivo comum partiria do professor. À medida que avança o desenvolvimento, esse objetivo comum se converteria também no objetivo da atividade das crianças, sendo que a organização a partir de fora se transformaria paulatinamente em organização interna da criança.

A tese defendida pelo autor é a de que a investigação do processo de desenvolvimento das funções psíquicas superiores aponta para uma origem social das mesmas, tanto do ponto de vista da filogênese quanto da 
ontogênese ${ }^{6}$. Na filogênese, as funções psicológicas superiores originam-se do desenvolvimento histórico do ser humano enquanto ser social, e não de uma evolução biológica. $O$ mesmo ocorreria na ontogênese, relativamente ao desenvolvimento da criança, quando a organização e estruturação das formas superiores da atividade psíquica se realizam no processo de desenvolvimento social da criança, em sua inter-relação e colaboração com o meio social circundante:

a observação do desenvolvimento das funções superiores demonstra que a formação de cada uma delas está rigorosamente subordinada à mesma regularidade, ou seja, que cada função psíquica aparece no processo de desenvolvimento da conduta duas vezes: primeiro, como função da conduta coletiva, como forma de colaboração ou interação, como meio de adaptação social, ou seja, como categoria interpsicológica e, em segundo lugar, como modo da conduta individual da criança, como meio de adaptação pessoal, como processo interior da conduta, ou seja, como categoria intrapsicológica (VYGOTSKI, 1931b, p. 214, tradução nossa).

Para o autor, acompanhar a transformação das formas coletivas de colaboração em formas individuais da conduta da criança significa também captar o princípio formativo das funções psíquicas superiores em seu porvir. O autor exemplifica essa tese utilizando o desenvolvimento da linguagem, alegando que no desenvolvimento infantil o caminho da linguagem se abre do exterior para o interior, como a forma fundamental de conduta coletiva, da colaboração social com os outros, converte-se na forma interior de atividades psicológica da própria personalidade, no processo de transformação da linguagem egocêntrica em linguagem socializada. Para ele, a linguagem egocêntrica funciona como meio de pensamento para a criança, cumprindo uma

\footnotetext{
6 A relação entre filogênese (desenvolvimento da espécie) e ontogênese (desenvolvimento do indivíduo desta espécie) é destacada na forma como a psicologia sócio-histórica entende o processo de formação do indivíduo humano. Para Vigotski, diferentemente do que acontece no desenvolvimento orgânico, o desenvolvimento cultural não pode prescindir da mediação, sendo a transmissão cultural do adulto à criança o principal fator do desenvolvimento humano (DUARTE, 2000).
} 
função importante ao assumir o papel de um primitivo pensamento verbal infantil, passando a atuar como linguagem interior no limite da idade préescolar e escolar.

Assim, os processos superiores do pensamento infantil surgiriam no processo de desenvolvimento social da criança por meio da incorporação das formas de colaboração assimiladas da interação com o meio social. Portanto, da experiência social da criança nascem as funções superiores da atividade intelectual. O desenvolvimento da personalidade da criança se manifesta sempre como função do desenvolvimento de sua conduta coletiva, da mesma maneira que as formas sociais de conduta transferem-se para a esfera de adaptação individual.

A deficiência e a falta de desenvolvimento das funções superiores se relacionam de forma diferenciada com o desenvolvimento insuficiente das funções elementares. O desenvolvimento incompleto das funções superiores em uma criança com deficiência mental aparece geralmente como um problema secundário, originado das particularidades primárias, não derivando diretamente de uma deficiência, mas de complicações secundárias, terciárias, enfim, dos sintomas originados da deficiência. O autor conclui daí que as maiores possibilidades de desenvolvimento da criança com deficiência estariam no campo das funções superiores e não no campo das funções inferiores. Isso se deve ao aparecimento posterior das funções superiores, sendo essas, portanto, as primeiras a se desagregarem na presença de fatores patológicos, que agiriam numa relação inversa ao desenvolvimento (que parte das funções inferiores para as superiores). O desenvolvimento incompleto dos processos superiores não está condicionado pela deficiência de modo primário e sim secundário, conseqüentemente, representam o elo mais fraco de toda a cadeia de sintomas da criança com deficiência e, portanto, o lugar para o qual devem estar orientados todos os esforços da educação a fim de romper a cadeia neste ponto mais fraco. 
A partir daí, Vigotski (1931b) chega à importantíssima conclusão de que as funções superiores se desenvolvem de maneira incompleta na criança com deficiência devido ao seu isolamento da coletividade. Explica esse processo da seguinte forma: devido a uma determinada deficiência, aparece na criança uma série de particularidades que colocam obstáculos ao desenvolvimento normal da comunicação coletiva, de colaboração e interação dessa criança com as pessoas que a rodeiam. $\mathrm{O}$ isolamento da coletividade ou a dificuldade do desenvolvimento social, por sua vez, determina o desenvolvimento incompleto das funções psíquicas superiores, que surgiriam em relação direta com o desenvolvimento da atividade coletiva da criança no curso do desenvolvimento normal. Mas a coletividade (como fator de desenvolvimento completo das funções psíquicas superiores), diferentemente da deficiência (como fator do desenvolvimento incompleto das funções elementares), se encontra em nossas mãos (grifo meu): “assim como é praticamente inútil lutar contra a deficiência e suas conseqüências diretas, é, ao contrário, legítima, frutífera e promissora a luta contra as dificuldades da atividade coletiva" (VYGOTSKI, 1931b, p. 223, tradução nossa). Passa ao primeiro plano, portanto, o problema da atividade coletiva/socialização da criança com deficiência, abrindo um campo de atuação para a intervenção pedagógica.

Vigotski defende que as coletividades compostas por crianças com diferentes graus de deficiência, principalmente nos casos de atraso profundo, são as mais produtivas, ao contrário do que busca a prática pedagógica tradicional:

na relação social se produz uma espécie de mútuo benefício. Aquele que é intelectualmente mais dotado adquire a possibilidade de manifestar sua atividade social com respeito ao que é menos dotado e ativo. Este último, por sua vez, tira da comunicação social com o mais ativo aquilo que lhe é inacessível, o que freqüentemente constitui um 
ideal inconsciente para o qual tende a criança intelectualmente deficiente (VYGOTSKI, 1931b, p.224, tradução nossa).

$\mathrm{O}$ autor comenta que a maior parte das pesquisas sobre coletividades de crianças com deficiência detém-se em aspectos formais (como atividade motora e momentos de desinibição), e que, se focassem as mudanças profundas que a personalidade dessas crianças experimenta e que se ocultam por trás destes momentos formais, "veríamos que cada um dos que ingressam na coletividade adquire, como se se fundisse num todo, novas qualidades e particularidades" (VYGOTSKI, 1931b, p. 225, tradução nossa). Depreende daí os prejuízos causados pela acomodada postura pedagógica que busca a homogeneidade, agindo contra os agrupamentos que naturalmente se estabeleceriam entre diferenças e enfatizando, ao invés de atenuar, a causa imediata que determina o desenvolvimento incompleto das funções psíquicas superiores. Vigotski faz uma afirmação crucial:

é fácil imaginar que as conseqüências de uma educação incorreta altera muito mais as possibilidades reais de desenvolvimento da criança com deficiência do que da criança normal, e sabe-se bem até que ponto uma criança normal, privada das condições adequadas de educação, pode apresentar tamanho abandono pedagógico que tornase difícil distingui-lo do verdadeiro atraso mental (1931b, p.225, tradução nossa).

No texto "Anomalias do desenvolvimento cultural da criança" (1928), Vigotski afirma que, no processo de desenvolvimento cultural, a criança assimila não só o conteúdo da experiência cultural, mas também os métodos e modos da conduta cultural e do pensamento, dominando paulatinamente os meios culturais criados pela humanidade durante seu desenvolvimento histórico, como por exemplo a linguagem e os símbolos matemáticos. 
Após este breve percurso pelas idéias de Vigotski, pode-se reiterar que para o autor é clara a preponderância do ambiente no desenvolvimento da criança, sendo de crucial importância caso a mesma tenha uma deficiência. A mediação do adulto, ou do contexto cultural, para o desenvolvimento da criança, não é apenas desejável, mas fundamental. A criança irá desenvolver-se, segundo Vigotski, em função das suas experiências com o contexto social em que está inserida, já que é pela internalização dessas experiências sociais que o seu psiquismo constitui-se. Daí decorre a afirmação do autor de que o desenvolvimento incompleto das funções superiores na criança com deficiência deverem-se ao seu isolamento do contexto social, planejado para aqueles que não têm deficiência. Assim, por exemplo, uma criança com uma deficiência visual não terá acesso a determinados produtos culturais, como a um livro, se não forem proporcionados recursos que possibilitem a ela o acesso a esse objeto, como a transcrição em braile. Proporcionados os recursos, a criança não estará mais isolada, e poderá participar mais amplamente da coletividade, misturando-se e interagindo com os outros de forma a incorporar elementos que ampliam suas possibilidades de desenvolvimento, bem como contribuir para o desenvolvimento dos outros participantes da coletividade. Como a sociedade é planejada para os ditos "normais", é preciso um cuidado redobrado para que a criança com deficiência não tenha suas possibilidades de desenvolvimento limitadas pela inadequação do contexto, o que é particularmente importante na escola, uma vez que é nesse ambiente que a criança experimentará atividades intencionalmente planejadas para o seu desenvolvimento.

A seguir, discutirei a contribuição da sociedade na construção social da deficiência a partir do proposto por Omote (1994), que vem corroborar a compreensão da deficiência a partir de uma perspectiva sóciohistórica, até aqui afirmada. 


\subsection{A deficiência como produção social}

Para analisar o conceito de deficiência de um ponto de vista que enfatiza o papel do contexto social e histórico em sua conceituação, é interessante observar as considerações feitas por Omote (1994) em relação à produção social da deficiência. Para este autor, a deficiência não pode ser considerada em si, mas sim em relação ao contexto social que lhe atribui maior ou menor desvantagem. Assim, o significado social da deficiência não pode ser atribuído a características inerentes a um indivíduo, mas a como estas características são valoradas em uma determinada cultura:

As abordagens centradas na pessoa deficiente ignoram o aspecto político do problema das deficiências e podem obscurecer ou camuflar áreas de possíveis problemas no interior de um grupo ou organização (equipes profissionais, famílias, escolas, instituições especializadas, etc.), invertendo até a relação de causa e efeito, na medida em que localizam no individuo a deficiência e muitas vezes, também, a sua causa (Omote, 1994, p. 68-69).

Essa maneira de abordar a questão nos parece fundamental para considerar a forma como a escola se relaciona com uma criança com deficiência a partir da sua cultura escolar, ou seja, dos valores que ali circulam e qualificam as relações ali estabelecidas. Omote (1994, p. 68-69) chama este fenômeno de construção social da deficiência, e defende que as reações das outras pessoas à deficiência são parte importante do fenômeno, reações que, no limite, definirão a pessoa como deficiente ou não-deficiente em um dado grupo social, e que não dependem das características objetivas da deficiência, mas da forma como tais características são interpretada em um dado contexto.

Uma teoria da deficiência não deve apenas explicar como as deficiências operam e como as pessoas deficientes funcionam, mas, ao mesmo tempo, deve ser capaz de explicar como as pessoas em geral lidam com as diferenças, especialmente aquelas às quais o grupo 
social atribui algum significado de desvantagem e descrédito social. Significa que tal teoria deve ser capaz de explicar também a nãodeficiência, que não é dada como tal, mas é construída socialmente através dos mesmos mecanismos de construção social da deficiência. A deficiência é destacada da normalidade pelo recorte que é feito em função de algum critério. Portanto, é a mesma teoria que precisa dar conta da explicação da deficiência e da não-deficiência.

A cultura escolar, traduzida nos valores que são veiculados em cada escola a respeito da questão da deficiência, terá uma importante influência na forma como os alunos com deficiência serão percebidos e tratados pelos diversos atores que a constituem.

Demonstrada a importância do contexto social para a criança com deficiência, o passo seguinte é discutir mais detidamente o ambiente escolar, pois, partindo-se dos aportes teóricos discutidos, acredita-se que, se este for organizado de forma a possibilitar a inclusão escolar, isso certamente irá se refletir nas práticas inclusivas da escola. Para essa discussão, utilizarei o conceito proposto por Sekkel (2003) de ambiente inclusivo.

\subsection{O conceito de ambiente inclusivo}

O conceito de ambiente inclusivo foi proposto por Sekkel (2003). De acordo com a autora,

para que a inclusão de crianças deficientes possa ser conduzida de forma acolhedora, sensível às necessidades das crianças e dos adultos envolvidos no processo educativo, é necessário que haja um ambiente de relações humanas que seja continente e, nesse sentido, esteja aberto à consideração das necessidades de todos: é necessário um ambiente inclusivo. Essa prerrogativa independe da entrada de crianças deficientes, e afirmo que é uma condição para uma educação orientada para as finalidades humanas (SEKKEL, 2003, p. 77). 
Um ambiente inclusivo, para a autora, estaria baseado, antes de tudo, nas formas de relações estabelecidas entre as pessoas do que um ambiente físico propriamente dito. É claro que pensar num ambiente inclusivo conduz à idéia de acessibilidade arquitetônica, mas não é esta a tônica da definição de Sekkel, e sim as relações estabelecidas num determinado espaço no caso, a escola. É interessante notar também que, na definição da autora, o ambiente inclusivo independe da presença de crianças com deficiência, sendo antes de tudo um espaço onde privilegia-se as relações humanas.

A autora conta, em seu trabalho, como foi o processo de implantação de um ambiente inclusivo na Creche Oeste da Universidade de São Paulo. Refletindo acerca do ambiente da creche antes deste processo, a autora considera-o "contrário à inclusão" (SEKKEL, 2003, p. 80), colocando como razões para tanto as relações cindidas entre educadores e a coordenação, atitudes corporativistas dos funcionários, apego da coordenação a uma proposta idealizada que dificultava a percepção da realidade da creche, entre outras questões. A autora avalia que "criou-se uma cultura institucional que era transmitida pelos que estavam há mais tempo na instituição e adotada por aqueles que chegavam" (SEKKEL, 2003, p. 80), o que vai ao encontro das definições sobre cultura institucional apresentadas anteriormente neste trabalho. O aspecto mais grave, contudo, parecia ser a desresponsabilização por parte dos educadores sobre o trabalho da creche

Podemos dizer que não estavam incluídos no próprio processo de trabalho: faziam aquilo que alguém lhes disse para fazer. Não eram co-autores de um projeto. Os furtos freqüentes concretizavam o sentimento de ameaça e de desapropriação. Desejo de ir embora. Havia um clima geral de desconfiança: atestados médicos falsos, furtos de materiais da creche e até das bolsas das funcionárias, ironias e um discurso que ocultava a falta de compromisso [...] Os sentimentos de raiva, humilhação, impotência etc., eram muito atuantes. Difícil ficar indiferente diante das provocações. Quando 
chegava algum funcionário novo, em poucos dias ele já estava situado e participando de um pacto que funcionava por adesão à idéia de que "aqui é assim", ao qual era muito difícil se opor, pelas próprias pressões internas (SEKKEL, 2003, p. 81).

A autora indica a mudança da cultura institucional como uma das mais difíceis tarefas que uma organização pode enfrentar, e bastante profundas. Pondera ainda que cada escola é um caso único de cultura institucional, fruto de um processo histórico que precisa ser repensado caso se almeje uma mudança institucional.

O reposicionamento das relações entre a coordenação e os funcionários é destacado por Sekkel (2003) como tendo um papel fundamental nas mudanças da Creche Oeste - USP, possibilitando a promoção de mudanças subseqüentes. As mudanças citadas pela autora foram na direção escolar e na equipe técnica (psicóloga e pedagoga), permanecendo, porém, a mesma proposta educacional. Neste trabalho onde pesquiso a direção escolar, é interessante notar que uma transformação profunda vivenciada por uma escola inicia-se com a mudança da direção, fato que provavelmente veio a reconfigurar algumas relações ali estabelecidas. Na seqüência, a autora descreve como postura da nova coordenação:

a coerência entre o que era dito e o que era feito, fundada no respeito e na confiança em quem diz e quem faz, e, no interesse verdadeiro pelo trabalho desenvolvido. Quando menciono o interesse verdadeiro, estou me referindo a um interesse que é comprometido com a prática, contextualizado, e que encontra tradução nas ações concretas do cotidiano. Não é só coerente, é também afetivo, investido de desejo: querer estar aqui, querer ver os avanços acontecerem. É esse afeto e coerência que, aliados à competência, permitem o sentimento de respeito e fazem surgir o lugar da autoridade democrática. [...] Creio que nesse momento se abandonou um modelo idealizado de creche (a creche do faz-de-conta?) que atuava de forma onipresente, como parâmetro para aferir o desenvolvimento da prática (que estava sempre aquém 
do desejado), e passamos a trabalhar a partir da reflexão sobre as situações concretas, com metas delimitadas a partir delas e elaboradas com a participação dos trabalhadores (SEKKEL, 2003, p. 83, grifos da autora).

Sekkel (2003) faz referência a uma autoridade que beneficia o grupo, representando as metas que busca atingir com o seu trabalho, considerando-o como uma autoridade democrática, baseada em objetivos que se clarificam para o grupo, e na capacidade de assumir a responsabilidade pelo próprio trabalho. A autora prossegue contando que os primeiros resultados não tardaram a surgir.

Entre as ações desenvolvidas com o grupo de trabalhadores, cita a formação continuada, onde todos os educadores teriam a oportunidade de entender os objetivos da creche, independente da função exercida. Ações coletivas, como a realização de um mosaico no muro da creche, com cada um contribuindo com uma parte, e investimento no registro das ações - a "memória da creche", descrevendo também a experiência chamada "círculos de qualidade", onde este conceito era discutido pelos trabalhadores da creche, possibilitando o fortalecimento do grupo, e maior participação das famílias no trabalho da creche. Em suma, a autora descreve uma série de sucessivas apropriações que vão sendo realizadas pelo grupo, e ainda que algumas questões devam ser retomadas e rediscutidas, num processo constante de construção, as mudanças obtidas apontam para ganhos qualitativos.

Em relação à inclusão de alunos com deficiência, Sekkel (2003) relata que, nos vinte anos de existência da creche, foram poucas as experiências no trabalho com crianças com necessidades educacionais especiais, porém um pequeno aumento na demanda nos últimos cinco anos foi acompanhado de um processo mais planejado. A creche convidou a Profa. Lígia Assumpção Amaral a partir de uma sugestão para que se aproveitasse o momento em que não havia ainda crianças com deficiência matriculadas para 
discutir a inclusão educacional, iniciativa bastante interessante e, infelizmente, rara, pois geralmente não é possível ao grupo de trabalhadores de uma escola preparar-se para receber uma criança com deficiência com antecedência. Para Sekkel (2003), essa experiência auxiliou os funcionários quando da efetiva entrada de crianças com deficiência, dando-lhes maior segurança e o sentimento de não estarem sozinhos nesa empreitada. A autora descreve a entrada de alguns alunos na creche, acompanhada sempre de um processo de discussão entre funcionários, pais e especialistas, o que, segundo ela, é um aspecto importante para a construção de um ambiente inclusivo, uma vez que as angústias e conquistas passam a ser compartilhadas.

Sekkel (2003, p. 153-154) faz algumas considerações importantes sobre o preparo dos educadores e da escola para receber crianças com diferenças significativas (expressão proposta, segundo a autora, pela Profa. Lígia Assumpção Amaral), como até que ponto a escola deve preparar-se, e se é possível prepara-se para tudo, bem como a indagação de quando a escola estará finalmente "pronta", e também, uma vez que a cultura institucional apresenta resistência às mudanças, até quando se deve tentar. É interessante ouvir a autora:

[...] esses relatos também evidenciam é que tem que haver respeito pelo processo do educador. Seria violento, tanto para o educador quanto para a criança, se essa aproximação fosse imposta. Esse respeito, no entanto, não pode representar um ponto final no processo de inclusão de crianças com diferenças significativas. É preciso ir além, respeitar, mas não renunciar, pois a inclusão é um direito da criança que também tem que ser respeitada. Nos vemos aqui diante da contradição: quem respeitar primeiro? Não acredito em tempos de preparação: esperar os educadores/funcionários receberem formação e se sentirem preparados para só então iniciar o movimento de inclusão. A situação é presente, concreta, as crianças, educadores, instituição, já estão ali, não há o que esperar. Penso que o movimento deve ser o seguinte: as crianças entram, e o ambiente institucional se 
move para dar acolhida onde for necessário, para crianças, pais, educadores/funcionários, criando espaços de troca, de escuta, de acertos, colocando as questões em discussão, elegendo as prioridades. Ninguém deve esperar em se tratando de questões ligadas à dignidade humana. A sensibilidade às reações dos indivíduos e das organizações que estão experimentando a mudança é importante. Entretanto, é fundamental que essa teoria da mudança não seja usada pelos indivíduos responsáveis por educar os alunos como uma desculpa para evitar que eles façam mudanças e ajam de maneira moral e eticamente coerente em prol dos alunos. Os educadores que mudaram com êxito suas práticas educacionais para criar escolas inclusivas e de qualidade relatam que uma visão progressiva da mudança, em que os indivíduos movem-se passo a passo através do processo e em que novos passos só são dados quando todos estão "na mesma página", não é necessariamente uma visão eficiente.

A autora pontua, de forma bastante coerente, qual deve ser a medida equilibrada entre o despreparo dos educadores e a necessária mudança institucional para acolher a educação inclusiva e a necessidade dos alunos - em suas palavras, "ninguém deve esperar em se tratando de questões ligadas à dignidade humana" (SEKKEL, 2003, p. 154). Assim, cabe aos profissionais da educação procurar as formas que atendam à necessidade e ao direito dos alunos, buscando neste processo maneiras de favorecer a participação de todos os envolvidos, a fim de facilitar o processo, e investindo sempre na formação e processos de discussão coletiva, onde parece estar o principal desencadeador para a construção deste ambiente inclusivo, na divisão de responsabilidades e méritos.

Os apontamentos de Sekkel (2003) reforçam a importância das ações coletivas na construção de um ambiente propiciador para a inclusão escolar, bem como o papel decisivo nesse processo que o diretor escolar pode ter. Na seqüência, pretende-se definir melhor o papel do diretor/gestor dentro da organização escolar. 


\subsection{Educação inclusiva: definição e questões atuais}

Até aqui, temos utilizado o termo educação inclusiva sem ter realizado uma explanação sobre o significado do mesmo. Cabe esclarecer que ao utilizarmos os termos educação inclusiva ou inclusão temos em mente o que foi preconizado na Conferência Mundial Sobre Necessidades Educativas Especiais promovida pelas Nações Unidas - UNESCO, realizada em 1994 na cidade de Salamanca, Espanha, a partir do que foi elaborado o documento Declaração de Salamanca sobre Princípios, Política e Prática na Área das Necessidades Educativas Especiais. Transcrevemos aqui a definição que consta na introdução deste documento:

Toda criança tem direito fundamental à educação, e deve ser dada a oportunidade de atingir e manter o nível adequado de aprendizagem;

Toda criança possui características, interesses, habilidades e necessidades de aprendizagem que são únicas,

Sistemas educacionais deveriam ser designados e programas educacionais deveriam ser implementados no sentido de se levar em conta a vasta diversidade de tais características e necessidades,

Aqueles com necessidades educacionais especiais devem ter acesso à escola regular, que deveria acomodá-los dentro de uma Pedagogia centrada na criança, capaz de satisfazer a tais necessidades,

Escolas regulares que possuam tal orientação inclusiva constituem os meios mais eficazes de combater atitudes discriminatórias criando-se comunidades acolhedoras, construindo uma sociedade inclusiva e alcançando educação para todos; além disso, tais escolas provêem uma educação efetiva à maioria das crianças e aprimoram a eficiência e, em última instância, o custo da eficácia de todo o sistema educacional. 
Mais adiante, o documento esclarece de forma mais detalhada o conceito de escola inclusiva:

O principio fundamental da escola inclusiva é o de que todas as crianças devem aprender juntas, sempre que possível, independentemente de quaisquer dificuldades ou diferenças que elas possam ter. Escolas inclusivas devem reconhecer e responder às necessidades diversas de seus alunos, acomodando ambos os estilos e ritmos de aprendizagem e assegurando uma educação de qualidade à todos através de um currículo apropriado, arranjos organizacionais, estratégias de ensino, uso de recurso e parceria com as comunidades. [...] O currículo deveria ser adaptado às necessidades das crianças, e não vice versa. As escolas deveriam, portanto, prover oportunidades curriculares que sejam apropriadas à criança com habilidades e interesses diferentes (UNESCO, 1994).

O conceito de necessidades educacionais especiais também merece uma melhor definição. Tomamos aqui a definição presente no artigo $5^{\circ}$ da Resolução CNE/CEB n ${ }^{\circ}$ 2, de 11 de setembro de 2001, que institui Diretrizes Nacionais para a Educação Especial na Educação Básica:

Consideram-se educandos com necessidades educacionais especiais os que, durante o processo educacional, apresentarem:

I - dificuldades acentuadas de aprendizagem ou limitações no processo de desenvolvimento que dificultem o acompanhamento das atividades curriculares, compreendidas em dois grupos:

a) aquelas não vinculadas a uma causa orgânica específica;

b) aquelas relacionadas a condições, disfunções, limitações ou deficiências;

II - dificuldades de comunicação e sinalização diferenciadas dos demais alunos, demandando a utilização de linguagens e códigos aplicáveis; 
III - altas habilidades/superdotação, grande facilidade de aprendizagem que os leve a dominar rapidamente conceitos, procedimentos e atitudes.

Os Parâmetros Curriculares Nacionais - Adaptações Curriculares, documento publicado pelo MEC em 1998, esclarecem que o termo necessidades educacionais especiais foi escolhido para destacar a diversidade que caracteriza os alunos, e não se restringe apenas à questão da deficiência. $\mathrm{O}$ trecho destacado, ainda que longo, foi aqui incluído por trazer de forma didática esta definição:

A expressão necessidades educacionais especiais pode ser utilizada para referir-se a crianças e jovens cujas necessidades decorrem de sua elevada capacidade ou de suas dificuldades para aprender. Está associada, portanto, a dificuldades de aprendizagem, não necessariamente vinculada a deficiência(s). $\mathrm{O}$ termo surgiu para evitar os efeitos negativos de expressões utilizadas no contexto educacional [...] Tem o propósito de deslocar o foco do aluno e direcioná-lo para as respostas educacionais que eles requerem, evitando enfatizar os seus atributos ou condições pessoais que podem interferir na sua aprendizagem e escolarização. É uma forma de reconhecer que muitos alunos, sejam ou não portadores de deficiências ou de superdotação, apresentam necessidades educacionais que passam a ser especiais quando exigem respostas específicas adequadas (BRASIL, 1998, p. 23).

Falar em necessidades educacionais especiais, portanto, deixa de ser pensar nas dificuldades específicas dos alunos e passa a significar o que a escola pode fazer para dar respostas às suas necessidades, de um modo geral, bem como aos que apresentam necessidades específicas muito diferentes dos demais. Considera os alunos, de um modo geral, como passíveis de necessitar, mesmo que temporariamente, de atenção específica e poder requerer um tratamento diversificado dentro do mesmo currículo (BRASIL, 1998, p. 24). 
A necessidade de que a escola se organize de forma a contribuir para a aprendizagem de cada aluno é apontada no referido documento: "escola inclusiva é, aquela que garante a qualidade de ensino educacional a cada um de seus alunos, reconhecendo e respeitando a diversidade e respondendo a cada um de acordo com suas potencialidades e necessidades" (BRASIL, 1998, p. 7).

A sala de aula de uma escola inclusiva deve ser um espaço aberto e dinâmico. A descrição de Saviani (2003, p. 118) de uma sala de aula de uma escola transformada é muito semelhante com o que entendemos ser uma sala de aula inclusiva:

Esta sala não tem carteiras fixas, é organizada para um número menor de alunos, não tem um centro, nela não existe uma mesa do professor que se destaca e as paredes são multicoloridas, cheias de cartazes. Por quê? Porque aí se parte do pressuposto de que quanto mais estimulado, tanto melhor o aluno aprende. Na pedagogia tradicional, partia-se do pressuposto de que o aluno deveria ser protegido de estímulos externos, porque tinha que concentrar sua atenção nas explicações do professor. Por isso a sala de aula tinha que ser silenciosa, de paredes opacas, para evitar estímulos que distraíssem a atenção, e também tinha que ser localizada num ponto que não fosse atingido por ruídos externos. Já para a pedagogia nova ocorre exatamente o inverso. Esta teoria preconiza que as crianças aprendem em atividade, interagindo com outras crianças sob orientação e supervisão do professor, respondendo aos estímulos e desafios do ambiente. Assim, a sala de aula é barulhenta em decorrência da multiplicação dos estímulos internos e externos. Isso que procurei mostrar por meio da contraposição entre a pedagogia tradicional e a pedagogia nova ocorre também com as demais teorias pedagógicas. Fica evidente, pois, que o próprio aspecto físico das salas de aula se modifica à medida que a concepção de educação se altera e vice-versa.

Não vamos retomar neste trabalho a evolução da educação inclusiva do ponto de vista histórico. Isso se deve ao fato deste tema já 
ter sido suficientemente bem explorado em trabalhos anteriores, dos quais destacamos, entre outros textos, o de Aranha (2001) e o de Mendes (2001).

Merece destaque o fato de que muitos estudos têm sido feitos em relação à questão da inclusão de alunos com necessidades educacionais especiais na escola regular, tanto do ponto de vista dos processos envolvidos como também em relação às concepções de professores sobre esse tema (ROSS, 2000; MATTOS, 2000; CUNHA, 2003). As mudanças demandadas aos sistemas para que a inclusão se efetive, como a previsão de apoios, flexibilizações curriculares e estratégias renovadas de ensino também vêm sendo constantemente pesquisadas (PICCHI, 1999; DEL MASSO, 2000; SAAD, 2002), bem como as necessárias políticas públicas para a efetivação da educação inclusiva (SILVA, 2000; PRIETO, 2000; SOUZA, 2002), indicando a relevância do tema no tecido social e educacional, e o desafio constante que se coloca na atualidade quanto à construção de uma educação escolar inclusiva.

A partir destas constatações, pretende-se investigar de forma mais detalhada na seqüência deste estudo o recorte proposto inicialmente, ou seja, a importância das relações mediadas pelo diretor escolar na efetiva inclusão de alunos com diferenças significativas no contexto de escolas regulares. 


\section{3}

\section{Gestão escolar}

\subsection{O diretor escolar}

A partir daqui, pretende-se fazer alguns esclarecimentos sobre os conceitos de direção escolar e de gestão escolar. Serão apresentados também alguns recortes teóricos sobre a função de gestão da escola.

Diretor ou gestor escolar? Para esclarecer sobre a adequação do uso destas denominações, inicialmente, cabe fazer a distinção entre administração e gestão escolar. No campo da Pedagogia, estas definições são relativas ao campo da administração escolar. Segundo Libâneo (2001, p. 78):

\footnotetext{
Para que as organizações funcionem e, assim, realizem seus objetivos, requer-se a tomada de decisões e a direção e controle dessas decisões. É este o processo que denominamos de gestão. Utilizamos, pois, a expressão organização e gestão da escola, considerando que esses termos, colocados juntos, são mais abrangentes que administração (grifos do autor).
}

Neste contexto, a direção é um dos processos da gestão de uma organização escolar: “Basicamente, a direção põe em ação o processo de tomada de decisões na organização, e coordena os trabalhos, de modo que sejam executados da melhor maneira possível" (LIBÂNEO, 2001, p. 78). O significado da direção irá variar de acordo com a concepção educacional da escola, mais diretiva ou mais participativa: "A direção pode, assim, estar centrada no indivíduo ou no coletivo, sendo possível uma direção individualizada ou uma direção coletiva ou participativa" (LIBÂNEO, 2001, p. 78-79). 
Dessa forma, optou-se por utilizar neste trabalho o termo diretor escolar e gestor escolar como sinônimos, uma vez que o uso consagrado do termo "diretor", ainda que revele certo ranço autoritário, indica, na linha da contradição, o que ainda se espera desse profissional à frente da gestão escolar, a "direção" do processo, a indicação do caminho a seguir, e é importante estar alerta para a instabilidade democrática em que a função do diretor escolar se encontra, ora oscilando para o autoritarismo, o que causa um certo artificialismo no uso do termo "gestor".

Considerando a literatura consultada e a finalidade deste trabalho, que é analisar o quê na gestão escolar favorece a criação de um ambiente educacional inclusivo, sugere-se que uma gestão participativa e democrática seja mais favorável à inclusão escolar.

Uma gestão democrática e participativa, de acordo com Libâneo (2001), procura atingir metas e cumprir responsabilidades decididas de forma coletiva e colaborativa, através da divisão de tarefas e do profissionalismo, uma tarefa de competência da direção e da coordenação pedagógica, e deve estar sempre em função da tarefa essencial da instituição escolar, que é a melhoria do processo ensino-aprendizagem através da busca de qualidade das práticas pedagógicas. Assim, os objetivos da escola passam a ser assumidos pelo grupo e estariam claros para todos os profissionais envolvidos, principalmente no que se refere à tarefa educativa da mesma, sua principal meta. O diretor implicado com a gestão democrática da escola exerceria sua função compartilhando responsabilidades com a equipe escolar e com a comunidade.

Paro (2001a) enfatiza a ligação entre gestão escolar e democracia, não apenas pela educação ser fator de acesso ao conhecimento artístico e cientifico da humanidade, mas pela sua possibilidade de trabalhar no sentido de desenvolver valores democráticos junto aos alunos. Vem daí a 
importância do espaço escolar estar de acordo com um local que propicie o exercício democrático, devendo a gestão caracterizar-se, principalmente, pela cooperação e pela solidariedade, favorecendo a ética e a liberdade, e não se restringindo a momentos pontuais como reuniões de conselhos.

Segue-se uma apresentação didática sobre as funções do diretor proposta por Libâneo (2001, p. 181-183):

O diretor de escola é o dirigente e principal responsável pela escola, tem a visão de conjunto, articula e integra os vários setores (setor administrativo, setor pedagógico, secretaria, serviços gerais, relacionamento com a comunidade etc.). Em outros tempos, muitos dirigentes escolares foram alvo de críticas por práticas excessivamente burocráticas, conservadoras, autoritárias, centralizadoras. Embora aqui e ali continuem existindo profissionais com esse perfil, hoje estão disseminadas práticas de gestão participativa, liderança participativa, atitudes flexíveis e compromisso com as necessárias mudanças na educação. As funções do diretor são, predominantemente, gestoras e administrativas, entendendo-se, todavia, que elas têm conotação pedagógica, uma vez que referem-se a uma instituição e a um projeto educativos e existem em função do campo educativo (grifos do autor).

Para Libâneo (2001, p. 114-115), o diretor de uma escola tem objetivos diferenciados do diretor de uma organização, pois implica em intencionalidade da ação educativa e posicionamento diante dos objetivos sociais e políticos assumidos pela escola:

O caráter pedagógico da ação educativa consiste precisamente na formulação de objetivos sócio-políticos e educativos e na criação de formas de viabilização organizativa e metodológica da educação (tais como a seleção e organização dos conteúdos e métodos, a organização do ensino, a organização do trabalho escolar), tendo em vista dar uma direção consciente e planejada ao processo educacional. O processo educativo, portanto, pela sua natureza, inclui o conceito de direção. Sua adequada estruturação e seu ótimo funcionamento constituem 
fatores essenciais para se atingir eficazmente os objetivos de formação. Ou seja, o trabalho escolar implica uma direção. (grifos do autor).

Qual o papel que as funções pedagógicas da escola exigem do diretor? Essa questão tem algumas interpretações divergentes. Para Libâneo (2001, p. 87-88), as funções administrativas seriam as mais pertinentes, sendo a parte pedagógica delegada ao coordenador, ainda que acredite que o conhecimento pedagógico deva permear a atuação do diretor:

o diretor de escola é o responsável pelo funcionamento administrativo e pedagógico da escola, portanto, necessita de conhecimentos tanto administrativos quanto pedagógicos. Entretanto, na escola, ele desempenha predominantemente a gestão geral da escola e, especificamente, as funções administrativas (relacionadas com o pessoal, com a parte financeira, com o prédio da escola e os recursos materiais, com a supervisão geral das obrigações de rotina do pessoal, relações com a comunidade), delegando a parte pedagógica ao coordenador ou coordenadores pedagógicos.

Numa sociedade capitalista, de acordo com Paro (2002), o diretor escolar assume um papel contraditório, pois tem que exercer a função de educador, visando atender os objetivos educacionais da escola e, ao mesmo tempo, administrar a escola de acordo com as orientações do sistema de ensino, que, na maioria das vezes, são de ordem burocrática e consomem grande parte do tempo de trabalho do diretor, dificultando inclusive a resolução dos problemas do dia-a-dia da unidade escolar, de ordem estrutural, material, pessoal, etc. A função de educador do diretor acaba passando para segundo plano. O diretor também estaria submetido à dupla pressão: por parte dos trabalhadores da escola, alunos e pais em suas reivindicações de melhores condições de trabalho e de ensino, e por parte do Estado, como o funcionário que deve cumprir orientações superiores. A forma como o diretor lida com esse conflito pode implicar na maneira como é visto pelos demais agentes do processo pedagógico. 
A posição é delicada, e para Paro (2002) este conflito não tem solução numa sociedade organizada como a nossa, marcada pelas relações de produção capitalistas. Apesar disso, o diretor, dada a posição de comando que ocupa, não é visto em sua subordinação a estes determinantes sociais maiores e que o tornam impotente para resolver as questões cruciais que se apresentam no cotidiano escolar. Em função disso, o diretor acaba assumindo o papel de gerente reservado pelo Estado, garantindo desta forma a manutenção dos interesses predominantes em relação à educação escolar. Contudo, o mesmo autor adverte que tais determinantes estruturais não devem servir como desculpa para a passividade, e que a transformação das práticas cotidiana é a base da transformação da sociedade de forma efetiva e duradoura.

A contradição entre o papel de legislador versus o de educador é também apontada por Lucchesi (1997, p. 238-239), uma vez que a forma como o Estado conduz a organização educacional leva o diretor a privilegiar seu papel legislador dentro da escola em detrimento ao de educador e gerenciador das relações. Assumir essa postura pode fazer com que o diretor entre em conflito com os interesses da comunidade escolar, caso esses sejam discordantes das determinações do Estado, podendo até ser perdido de vista que a participação da comunidade é uma orientação prevista constitucionalmente por este mesmo Estado. Mais uma vez, se está diante de um processo marcadamente contraditório.

Quanto às dificuldades na implantação da gestão democrática, Torres e Garske (2000) sugerem que parece haver um esforço de conciliação por parte dos diretores entre a intenção de ser democrático e a manutenção do comportamento clientelístico como questão de sobrevivência institucional. Para as autoras, a pressão política exercida sobre as Secretarias de Educação leva à rotatividade de políticos e à descontinuidade de projetos, criando um cenário onde acordos que conservam formas de funcionamento conservadoras acabam sendo comuns. 
Em relação ao papel político exercido pelo diretor escolar, segundo pesquisa realizada por Castro (2000, p. 83), o papel deste profissional ainda é nebuloso, sendo seus critérios de seleção marcadamente políticos. Para a autora, o diretor escolar é visto como responsável por tudo o que acontece na unidade, porém seu papel não fica claro, sendo que a labilidade de critérios acaba por contribuir para a desvalorização do papel de diretor e, ao mesmo tempo, favorecer o aparecimento de critérios políticos, que cada vez mais dificultam a avaliação da competência desse profissional.

Quanto ao processo de implantação da democratização na escola, Torres e Garske (2000) consideram que no Brasil esse processo esteve tensionado entre os movimentos de centralização e descentralização, com os sistemas de ensino buscando a transferência de responsabilidades entre si, notadamente as de ordem financeira. Os autores alertam contudo que, ainda que no Brasil a orientação governamental fosse para uma administração da educação calcada em princípios empresariais, autoritários e hierarquizados, não se pode esquecer que a esta ocorre no espaço da escola, local marcado por contradições e embates entre forcas conservadoras e progressistas.

Vários estudos têm sido feitos acerca de aspectos importantes para a democratização do espaço escolar. A função de líder democrático e pesquisador do diretor (VIANNA, 1992), o papel da gestão na implementação de reformas educativas com finalidade descentralizadora (MATTOS, 1999), o fortalecimento do coletivo escolar e a autoridade exercida como produto da relação pedagógica (SILVA, 2001), a democratização das relações que ocorrem na escola (LOPES, 2002) e a atuação do diretor junto à comunidade (XIMENES, 2003) podem ser citados como exemplos desses estudos. A influência do diretor na constituição de dado clima escolar e no tratamento à diferenças e valores individuais também vem sendo apontada (LACERDA, 2003). 
O diretor seria, segundo Saviani (2000, p. 207), o principal responsável nos limites da unidade escolar, definindo-se seu papel de forma geral como o de "garantir o bom funcionamento da escola". Para esclarecer o que seria tal função, este autor adverte para que se considere o papel principal da escola enquanto instituição de natureza educativa, cabendo então ao diretor "garantir o cumprimento da função educativa que é a razão de ser da escola" (SAVIANI, 2000, p. 207). Para Saviani (2000, p. 207), portanto, o diretor deve ser antes de tudo um educador, enfatizando esta tarefa em detrimento da de administrador, defendendo que "em termos típico-ideais, ele deveria ser o educador por excelência dado que, no âmbito da unidade escolar lhe compete a responsabilidade máxima em relação à preservação do caráter educativo da instituição escolar". Ao diretor caberia a mediação entre duas forças exercendo pressão constante e contrária, isto é, de um lado, o sistema e suas exigências, e de outro, as finalidades educativas da escola. Em relação a este papel, Saviani (2000, p. 209) defende que

\footnotetext{
um diretor será tanto mais educador quanto maior o grau de autonomia que mantém em relação às exigências do "sistema", subordinando suas formas aos conteúdos educativos; e será tanto mais administrador quanto menor o grau de autonomia referido, o que o levará, em conseqüência, a se ater à rigidez das "normas superiores" mantendo-as esvaziadas do conteúdo que lhes daria sentido.
}

Romão e Padilha (2001) apontam para o fato das práticas atuais de gestão exigirem uma maior participação do diretor na esfera administrativa, obrigando-os a deixar num plano secundário aquilo que caracterizaria sua função mais importante, ou seja, sua atuação nas questões pedagógicas. Muitos diretores, ao se queixarem da dificuldade de administrar sozinhos a escola, denunciam nesta fala o isolamento vivenciado por eles nesta tarefa. 
Exercer seu papel de educador é dificultado ao diretor pelas exigências administrativas de cunho capitalista que são feitas pelos sistemas educacionais às escolas, como apontado por Reis (2000) e Lyra (2003). Esta tendência vem crescendo nas políticas educacionais governamentais influenciadas pelas tendências neoliberais dominantes a partir da década de 90 do século $X X$, que acabam por enfatizar os aspectos administrativos da gestão escolar, trazendo para o campo desta metodologias produzidas no bojo das administrações empresariais.

A descentralização administrativa e financeira dos sistemas educacionais, que confere maior autonomia administrativa às escolas, segundo Bruno (1993, p. 138), exige em contrapartida uma maior participação de todos os envolvidos com a educação em uma unidade escolar, pois a descentralização aumenta suas responsabilidades. Nesse panorama, é importante que o papel do diretor seja legitimado, e o autor cita a eleição de diretores como uma possibilidade para que isso ocorra, ainda que de forma incipiente, dada as formas como processos eleitorais costumam ocorrer no Brasil, ainda geralmente subordinados a acordos políticos e compromissos com interesses externos à coletividade envolvida.

Num ponto de vista convergente com a principal atribuição do diretor ser a de educador e não a de administrador, Silva Jr. afirma de forma contundente que "as escolas não existem para serem administradas ou inspecionadas: elas existem para que as crianças aprendam." (SILVA JR. apud LUCCHESI, 1997, p. 231).

Segundo Lucchesi (1997, p. 231), “as relações de poder e autoridade na escola pública não seguem a racionalidade que o sistema escolar lhes atribui, estando sujeitas ao jogo de interesses pessoais e aos atributos de personalidade dos indivíduos que exercem o cargo de diretor". O autor ressalta a premência da capacidade de articulação e construção na tarefa de administrar 
um espaço público como a escola. Lidar com esta tarefa implica em lidar com maior ou menor clareza com o poder, e isto é um tema com que o diretor se confronta de forma cotidiana, quer tenha ou não consciência disso.

Assim, o diretor acredita-se no papel - ou a ele é atribuído - de gerenciador da "verdade educacional". Portanto, acaba privilegiando em sua ação o papel de principal executor das leis na instituição escolar, tornandose refém, muitas vezes, desse recorte em sua atuação. Para Lucchesi (1997), isso acaba fazendo com que o diretor privilegie em sua ação as demandas relativas às demandas legais do cargo, sem que tenha condições para lidar com as questões que surgem do cotidiano escolar de forma efetiva. Portanto, caberia ao diretor estar atento às relações de poder presentes no cotidiano escolar. O legal, no espaço da escola, é legitimo enquanto construção articulada entre os diferentes atores, sem o que o diretor arrisca-se a tornar-se um mero representante do poder de plantão.

O entendimento do cotidiano escolar para a implantação de reformas educacionais é muito importante, segundo Schneckenberg (2000). Para a autora, aquilo que vai facilitar ou dificultar a mudanca na escola surge no cotidiano escolar, ora de forma autônoma, ora relacionado à estrutura social mais ampla. Refletir sobre esse cotidiano é condição essencial para os atores escolares empenhados em reformas, sobretudo para o diretor, que carregam a responsabilidade de conduzir o processo de mudança.

Assim, ao se pensar na implantação de uma cultura inclusiva na escola, o cotidiano que ali se constrói e reconstrói deve ser considerado como fundamental. Isso não significa, contudo, que se deva desconsiderar o contexto social mais amplo, como adverte Frigoto (1997), no sentido que as ações devem buscar a superação do localismo e ampliar-se, considerando a realidade nacional e global, em busca de um processo verdadeiramente democrático. Os atores da escola devem ter em mente que as 
mudanças que ali ocorrem são reflexos de anseios maiores e, no caso da educação inclusiva, reflexos da luta pelos direitos humanos que tem se fortalecido desde os anos sessenta do século vinte.

Considerando o aspecto político-organizacional dos sistemas, o diretor é parte importante na montagem e execução de uma política educacional. Gadotti (2001) enfatiza a importância da relação entre o diretor e as secretarias de educação municipais e estaduais serem diretas, uma vez que este é o principal parceiro na implantação das políticas educacionais.

Em artigo publicado no jornal Folha de São Paulo em 23/09/2005, o número expressivo de diretores indicados para o cargo pelos governos municipais ou estaduais (cerca de 60\%, segundo o INEP - Instituto Nacional de Estudos e Pesquisas Educacionais Anísio Teixeira) é citado como um indicador do atraso educacional brasileiro. O cargo de direção ainda é tratado como cargo político, sendo trocado de acordo com a administração.

A constatação de que muitos desses gestores são inseguros quanto à legislação e ao projeto de uma educação municipal, indicando a dificuldade de se ver como participante de uma ação de articulação pertinente a uma política pública, foi feita por Galera (2003), ao pesquisar as concepções de diretores e secretários de educação. A autora concluiu que muitos gestores ainda não têm claro os conceitos sobre gestão, revelando lacunas de concepção e formação. Em sua pesquisa, Galera (2003, p. 84) aponta para "o verdadeiro abandono em que se encontram os pequenos municípios brasileiros. Quando 25\% não consegue associar gestão e políticas públicas, como estará sendo realizada a ação prática desse gestor?".

É importante, portanto, que o papel do diretor como formador e suas demandas formativas continuem a ser pesquisados (MORETO, 2002 e BARROS, 2004). Para tanto, vale lembrar a relação fundamental entre o 
papel formativo do diretor na construção do projeto político pedagógico da escola (BRITO, 2002 e MONTEIRO, 2003).

Também se deve considerar que a identificação das necessidades formativas de seus profissionais é uma das tarefas que os sistemas de ensino devem empreender a fim de implementar políticas públicas, como indica Prieto (2002). No âmbito das unidades escolares, para a autora, deve-se promover a participação dos envolvidos com as atividades de ensino na construção de um projeto pedagógico que esteja afinado com os objetivos maiores da educação previstos na legislação, visando a permanência a escola com qualidade, a partir da apropriação e produção de conhecimentos, e a participação social.

Vale (1993) afirma que o papel do diretor enquanto mediador da ação pedagógica da escola é fundamental, sendo sua responsabilidade o projeto pedagógico da Escola. O trabalho coletivo é necessário para que a escola enfrente a magnitude de seus desafios, que não podem ser enfrentados de maneira individualizada. $O$ trabalho coletivo também é crucial para a sobrevivência institucional do diretor, o que é indispensável na coordenação das diferentes ações e recursos, bem como para catalisar os esforços de todos os envolvidos.

O protesto de diretores filiados ao UDEMO (Sindicato de Especialistas de Educação do Magistério Oficial do Estado de São Paulo) em 1979 é lembrado por Nogueira (1993). Nesta ocasião, os diretores recusaram-se a entregar o nome de professores em greve, com o grito "diretor não é feitor, é educador!". A partir do processo de democratização da sociedade brasileira, a própria palavra "diretor" acaba sendo questionada, ganhando força a idéia de gestão democrática e administração da escola por conselhos consultivos, ou mesmo deliberativos, ainda que a tradicional participação política insuficiente em nossa sociedade dificulte esse processo. Sobre os conselhos de escola, a 
autora afirma que os mesmos ainda não se constituem como espaços de uma verdadeira participação da comunidade, no sentido do auto-gerenciamento da unidade escolar, no levantamento de questões e autonomia no encaminhamento de soluções. Porém, sua existência provoca polêmica, principalmente quando os setores mais conservadores argumentam pelo suposto despreparo dos pais para esta tarefa e o esvaziamento da autoridade do diretor. Nogueira (1993) lembra, contudo, que não há outra forma de aprender a participar democraticamente se não participando. Desta forma, o diretor não estaria sendo destituído de sua liderança e sim a exercitando através do compartilhamento das responsabilidades com pais, alunos e professores, num verdadeiro exercício de cidadania que beneficia a todos os envolvidos. Para tanto, a transformação do diretor em um educador-dirigente é necessária, a fim de que possa envolver toda equipe escolar na tarefa de transformar a escola estimulando a iniciativa dos professores e favorecendo ações coletivas.

A contribuição de Araújo (2002) para esta questão se dá através da análise de que a centralização das decisões na figura do diretor ou da equipe gestora não permite o diálogo e o movimento de reorganização periódica na busca de respostas cada vez melhores para os desafios cotidianos. $\mathrm{O}$ autor questiona a viabilidade de professores que vivem em um ambiente autoritário para desenvolver um trabalho de autonomia com seus alunos. Para ele, a gestapo democrática da escola passa pela participação efetiva da comunidade escolar no projeto pedagógico e nas políticas administrativas desse espaço.

A partir da literatura aqui analisada, pode-se dizer, em resumo, que o diretor é o grande articulador da escola enquanto uma cultura, um facilitador e um dificultador de processos, sendo mais influente na medida em que centraliza mais decisões e pulverizando sua influência na medida em que a gestão se democratiza, não deixando com isso de exercer um papel de liderança. A experiência mostra, contudo, que ainda são raras as escolas que 
têm a gestão democrática como uma prática incorporada em seu dia-a-dia, indicando que a gestão escolar ainda se encontra fortemente centralizada na figura do diretor, não sendo comum a atuação desse profissional como articulador de uma equipe, mas como um centro de decisões isoladas e de responsabilidades junto aos sistemas educacionais que pouco se articulam com os anseios da comunidade escolar.

\subsection{O diretor enquanto articulador de mudanças: em busca de uma escola inclusiva}

O diretor é uma figura essencial para a implantação e o desenvolvimento de qualquer inovação pedagógica, bem como para sua continuidade e para desenvolvimento bem sucedido, de acordo com Lima (1993, p. 117), pois "do ponto de vista do microssistema, ou seja, da unidade escolar, o diretor pode criar, permitir ou tolerar a abertura de novos espaços necessários à transformação do cotidiano escolar".

A flexibilidade do diretor e sua abertura para experimentar outras ações é apontada por Almeida (2003) como uma condição para considerar a validade de posições contrárias à sua. Ganhar espaço para a divergência e a diferença cria um dinamismo que vai contra as práticas tradicionais de administração, possibilitando um processo de abertura na escola a partir da participação de todos os seus agentes.

Segundo Glatter (1995, p. 159), é importante considerar que a cultura da escola pode frustrar um processo de mudança, onde uma aceitação aparente camufla a recusa à mudança de práticas. Neste sentido, a autora argumenta que um dos papéis importantes da direção de uma escola é o de gerir através do exemplo, buscando influenciar a cultura escolar por aplicações concretas e não somente argumentos. Evidenciar para o grupo que o 
diretor pratica as ações em que acredita mostra que os valores que ele detem são possíveis, bem como que sua atuação não fica apenas no nível do discurso. Para a autora, "as 'mensagens' que os alunos recebem da direcção da escola devem ser congruentes com as atitudes pedagógicas nas salas de aula: no mínimo, os valores e objectivos subjacentes aos dois tipos de actividade devem ser compatíveis".

Sage (1999, p. 238) tece algumas considerações importantes ao refletir sobre o papel do diretor na constituição de uma escola inclusiva. Para este autor,

\begin{abstract}
a maneira pela qual os diretores exercem as forças simbólicas e culturais através de suas atitudes e comportamento é particularmente importante quando se exemplificam as ações e as atitudes necessárias para a prevalência de um ambiente inclusivo nas escolas. Primeiramente, o comportamento do diretor é que estabelece o clima pelo qual se resolve que a escola é de todas as crianças. Segundo, o comportamento cooperativo do diretor e dos demais administradores proporciona um modelo para os professores que precisam de ajuda para romper com a prática de "trabalhar sozinhos".

Em documento orientador do Ministério da Educação -
\end{abstract} MEC relativo à implantação de sistemas educacionais inclusivos (2004), ressalta-se mais uma vez o papel fundamental exercido pela direção escolar na constituição do grupo para que trabalhe de forma cooperativa e organizada, tendo como objetivo as metas estabelecidas no projeto pedagógico da escola.

As mudanças necessárias para a implantação efetiva da educação inclusiva, segundo Sage (1999, p. 129-130), não ocorrem espontaneamente, bem como não se pode preparar para então começar a receber alunos com deficiência, mas as mudanças devem se de forma concomitante, uma vez que envolvem desde questões administrativas até a organização da sala de aula. Para o autor, os diferentes setores da escola têm o 
diretor como um participante essencial, enfocando como decisiva para a mudança a prática cotidiana do diretor. O ponto de vista do autor é coerente com o defendido por Sekkel (2003) no sentido de sublinhar a importância da construção de um ambiente escolar inclusivo. Sage (1999, p. 130) cita a seguinte recomendação do Council of Administrators of Special Education ${ }^{7}$ da Inglaterra:

A primeira medida da direção da escola é construir uma comunidade escolar inclusiva, baseada nos propósitos da escola. O planejamento e o desenvolvimento do currículo que conduz aos resultados esperados pelo Estado e pelos setores educacionais devem vir logo em seguida.

$\mathrm{O}$ autor adverte ainda que para que um sistema escolar inclusivo se efetive é necessário considerar o sistema como um todo, e não como tendo uma estrutura de ensino regular e uma de ensino especial. Para tanto, os sistemas devem não só colocar isso em termos de princípios, mas principalmente adotar ações coerentes com a inclusão como fundamento. Mesmo no caso de um sistema possuir escolas ou apoios específicos para alunos com necessidades educacionais especiais, a matrícula deveria ser feita inicialmente em escolas regulares, onde a avaliação de caráter pedagógico se daria, ao invés de encaminhar os alunos para algum setor de triagem. Sage (1999) toca em um ponto nevrálgico ao refletir que a falta de apoio dos administradores do sistema acaba prejudicando os comportamentos inclusivos que professores e diretores buscam desenvolver. Para garantir as mudanças nas ações desses profissionais, o sistema deveria tomar posições claras e que demonstrem seu apoio explícito à implantação de uma educação inclusiva. Dessa forma, os sistemas permitem que os diretores das unidades escolares assumam seu papel na conquista da educação inclusiva em sua escola, não alimentando sua dependência do setor de educação especial de um dado sistema escolar. Sage (1999, p. 132-133) adverte ainda que

\footnotetext{
7 Conselho de Administradores da Educação Especial.
} 
embora há muito se reconheça que o comportamento e a liderança simbólica do diretor estabeleçam o clima cultural da escola, a extensão de suas responsabilidades de incluir todos os alunos na escola permanece obscura. Tem sido bastante aceitável que o diretor as transfira para um escritório central especializado em questões e decisões sobre os alunos com deficiência. $O$ deslocamento da responsabilidade primária do especialista para o generalista constitui uma mudança de papéis importante para ambas as partes.

Assim, caberia aos sistemas desenvolver uma atuação que sustente e suporte a ação da escola na implementação da educação inclusiva. Neste cenário, o diretor torna-se responsável por todos os alunos, e não apenas pelos alunos regulares ou que não apresentam necessidades educacionais especiais. O especialista ou a equipe técnica exerceria uma função de suporte à escola, mas não de controle, e ao professor de educação especial que atua no apoio a alunos com necessidades educacionais especiais matriculados no ensino regular não deve ser delegada a responsabilidade exclusiva pelas decisões a serem tomadas sobre os encaminhamentos pedagógicos mais adequados ao aluno.

Transcreve-se abaixo algumas crenças colocadas por Sage (1999, p. 133) como importantes para que essas posturas se estabeleçam de forma mais definitiva:

1. Todos na escola são responsáveis pela educação de cada aluno, desde a freqüência à escola, independentemente das necessidades de aprendizagem;

2. Todos na escola estão concentrados na satisfação das necessidades de todos os alunos em um sistema de educação unificado. A rotulação e a segregação são contraproducentes à excelência educacional;

3. Todos os professores têm habilidades e conhecimentos que devem ser usados para dar apoio aos esforços dos demais professores, para garantir o sucesso de todos os alunos em turmas regulares; 
4. Todos os alunos se beneficiam da participação em turmas e escolas inclusivas;

5. A prevenção de problemas de aprendizagem cabe à educação especial;

6. A avaliação das necessidades dos alunos é uma parte regular do planejamento curricular e didático para todos os professores e pessoal de serviço relacionado;

7. A educação especial e o pessoal de serviço atuam como membros integrantes dos grupos de professores, sob a liderança do diretor da escola;

8. A educação especial e o pessoal de serviço prestam serviços aos alunos no contexto do programa da escola regular;

9. Modelos de subvenção e orçamento dão suporte à provisão de serviços para alunos com necessidades especiais na escola e na comunidade locais;

10. Os Serviços comunitários para crianças são coordenados na escola;

11. A avaliação da eficiência do programa de uma escola inclui a consideração da adaptação pós-escolar dos alunos com necessidades especiais.

De forma específica em relação ao diretor, Sage (1999) defende que seu papel é de um facilitador, uma vez que a transformação da escola em uma escola inclusiva não pode ser legislada ou imposta, sob pena de ser sabotada ou estabelecida de forma fictícia. $O$ autor adverte ainda para a necessidade do diretor considerar o medo que a mudança produz, sendo mais uma vez destacada sua contribuição no sentido de encorajar novas práticas afinadas com a inclusão escolar.

Portanto, caberia ao diretor apoiar o professor que empreende ações para mudar e que pode ser visto com desconfiança inicial 
pelos seus pares, sem deixar de respeitar o ritmo pessoal de cada professor na incorporação de uma atitude inclusiva. Para Sage (1999, p. 138),

O diretor, mais que qualquer outro funcionário do sistema escolar, está em posição de entender e ser sensível ao status e às necessidades dos professores e de outros funcionários de serviço direto para desenvolver as atitudes e as habilidades necessárias para que as práticas inclusivas possam florescer. Quer através da avaliação formal das necessidades ou apenas conhecendo as pessoas com quem trabalha, o diretor deve ser capaz de discernir o que a equipe como um todo, e também seus membros individuais, necessitam para se desenvolver.

No documento do Ministério da Educação - MEC “Educação Inclusiva: a escola", (2004, p. 23), alerta-se quanto à importância do suporte ao professor - que é uma importante atribuição do diretor - na tarefa de provocar mudanças para tornar um sistema educacional inclusivo:

É importante que o procedimento de acesso ao sistema de suporte disponível seja regulamentado na escola, para evitar que o professor tenha que buscar ajuda apenas por iniciativa pessoal. A busca por iniciativa pessoal sobrecarrega o professor e deixa sem suporte o professor que não tem essa iniciativa. No primeiro caso, se fortalece a cultura de que a busca de soluções para problemas no ensino não é responsabilidade da gestão da escola, enquanto que no segundo, penaliza o processo de aprendizagem e o alcance dos objetivos reais da educação.

Na declaração de Salamanca (UNESCO, 1994), também se pode encontrar referências à importância do trabalho do diretor escolar no que toca à educação inclusiva:

Administradores locais e diretores de escolas podem ter um papel significativo quanto a fazer com que as escolas respondam mais às crianças com necessidades educacionais especiais desde de que a eles sejam fornecidos a devida autonomia e adequado treinamento para 
que o possam fazê-lo. Eles (administradores e diretores) deveriam ser convidados a desenvolver uma administração com procedimentos mais flexíveis, a reaplicar recursos instrucionais, a diversificar opções de aprendizagem, a mobilizar auxílio individual, a oferecer apoio aos alunos experimentando dificuldades e a desenvolver relações com pais e comunidades. Uma administração escolar bem sucedida depende de um envolvimento ativo e reativo de professores e do pessoal e do desenvolvimento de cooperação efetiva e de trabalho em grupo no sentido de atender as necessidades dos estudantes.

Pensar uma educação de qualidade para todos, de acordo com Mantoan (2001, p. 116), implica em mudanças na forma como a administração escolar é exercida, bem como nos papéis ocupados pelos membros da organização escolar. Ao se buscar uma direção mais coerente para os rumos da administração escolar "deixam de existir os motivos pelos quais esses profissionais ficam confinados aos gabinetes, sem tempo para conhecer o que acontece nas salas de aula e delas participar".

Em pesquisa destinada a levantar concepções de professores e diretores sobre educação inclusiva, Sant'Ana (2004, p. 243), apurou que a presença de uma equipe que dê suporte aos agentes educacionais é apontada mais por professores que diretores, ao passo que a formação continuada é vista como uma necessidade mais freqüentemente por diretores que professores. Para a autora, isso indica a necessidade que estes profissionais sentem de orientação e apoio para lidarem com alunos com necessidades educacionais especiais, apontando para a necessidade da escola tornar-se acolhedora a partir do "desenvolvimento de uma cultura escolar baseada no reconhecimento, na valorização e no respeito a todos os alunos".

Ao pesquisar o papel da gestão escolar na construção de uma escola inclusiva, Tezani (2004) encontrou uma relação expressiva entre a postura assumida pela gestão escolar e a influência na prática pedagógica 
cotidiana, ressaltando que o envolvimento dos pais e o comprometimento dos professores são fatores determinantes na construção da escola inclusiva.

Não foram encontrados na literatura revisada trabalhos que focassem o papel do gestor no processo de implantação da educação inclusiva segundo a perspectiva do diretor e dos profissionais da escola que trabalham em estreita relação com ele, como professores, coordenadores e técnicos ou mesmo a família de alunos com necessidades educacionais especiais e a comunidade atendida pela escola. Consideramos, portanto, que tal estudo seja pertinente dada a importância já analisada acima do gestor na constituição da cultura escolar a partir de um enfoque sócio-histórico, ou seja, que pondere a importância do contexto na constituição dos indivíduos que nele convivem e das relações ali construídas, considerando a contribuição de Vigotski para a reflexão sobre estes fenômenos, principalmente no sentido de realizar uma análise crítica do mesmo. 


\section{4}

\section{Metodologia}

\subsection{Metodologia de pesquisa}

Este estudo define-se desde sua origem e sua filiação teórica como um estudo qualitativo. O campo da investigação é a escola, mais especificamente a cultura escolar. Trata-se de um foco investigativo complexo e multifacetado, relacionado a muitos determinantes históricos, sociais e culturais. A possibilidade de conhecimento e reflexão sobre este conjunto de fatores relaciona-se com a convivência neste contexto e a análise cuidadosa de dados que, ao emergir, acabam por influenciar a própria sistematização inicial da investigação. Assim, considera-se que as possibilidades oferecidas por um estudo de tipo qualitativo respondam de forma mais significativa à fecundidade de aspectos que podem emergir de um campo de pesquisa como a escola.

O recorte de investigação a ser feito neste campo é o diretor escolar, ou mais precisamente, o papel do diretor na formação de uma cultura escolar inclusiva. Cabe aqui explicitar a localização um tanto nebulosa da fronteira entre o diretor-indivíduo e o diretor-institucional. Uso o termo "nebulosa" de forma intencional, pois o mesmo aponta para uma área indefinida entre o individual e o institucional que é destacada quando se cogita a origem social da constituição do indivíduo na sociedade humana. A base teórica desta investigação é a psicologia sócio-histórica, que tem como fundamento teórico que a construção do ser humano se dá em função da sua condição de ser social, participante desde o nascimento de uma cultura, e seu desenvolvimento se dá em sucessivas mediações com este contexto, por 
mecanismos como internalização e apropriação, de forma constante e dialética. Deste ponto de vista, não se pode considerar que se possa isolar o diretorindivíduo de um contexto institucional - a escola, que dialeticamente o influencia e é por ele influenciada.

Olhar para o diretor-indivíduo é também olhar para a confluência dos muitos fatores históricos e culturais que o constituíram de forma única. Mas este é o limite deste olhar, pois não se pretende buscar sua subjetividade, mas sim o campo da relação entre ela e o contexto escolar. Considerando-se o contexto escolar, admite-se que sua conformação específica também resulta de uma série de fatores histórico-culturais, que vão desde o sistema educacional brasileiro até o tipo de legislação específica a que esta escola específica esteja submetida, o que definiria de forma objetiva os limites de atuação do diretor, bem como a população atendida, os professores, a formação do bairro e uma infinidade de recortes possíveis. Desta forma, considera-se que o diretor é uma peça importante na configuração de uma cultura escolar, mas não é determinante. Na linha da contradição, entretanto, é preciso observar que existe um poder de atuação e de transformação que compete ao indivíduo integrante de um sistema. Frente a uma determinação de uma secretaria de educação, por exemplo, um diretor pode omitir-se, insurgirse ou negociar possibilidades. Nas experiências escolares, são comuns os relatos de melhorias de instalações, por exemplo, conseguidas por intervenção pessoal do diretor junto às instâncias administrativas. Daí decorre que, dentro de um mesmo sistema, submetido às mesmas regras, é possível encontrar uma grande variedade de posturas e de resultados frente a uma mesma determinação ou orientação. Esta diferença é um campo que nos interessa investigar, ainda que de forma inicial.

Inicialmente, considerei a realização de uma comparação entre concepção de diretores acerca da educação inclusiva e sua possibilidade de ação frente a sua efetivação na escola. Para tanto, pensava em enfocar as 
concepções de diferentes diretores que tivessem se sucedido na direção de uma mesma escola, considerada como um campo interessante para o estudo por razões que explicitarei adiante. Não me interessava comparar escolas, pois queria me aprofundar no contexto desta escola, na apreensão da sua cultura e na influência que diferentes diretores teriam tido na constituição da mesma. A partir da discussão ocorrida no exame de qualificação, no entanto, destacou-se a necessidade de aprofundamento nas relações possíveis protagonizadas por um diretor em detrimento à comparação entre diferentes diretores, o que traria uma maior riqueza para a discussão. Assim, este estudo foi tomando a configuração de um estudo de caso.

$\mathrm{O}$ estudo de caso define-se mais pelo interesse do pesquisador em casos individuais do que pelo método de pesquisa utilizado, de acordo com Stake (2000, p. 436): “um estudo de caso é ao mesmo tempo o processo de investigação sobre o caso e o produto desta investigação" (tradução nossa). Partindo da classificação proposta por este autor, o estudo de caso em questão seria do tipo instrumental, ou seja, um caso particular que é examinado com o objetivo principal de fornecer esclarecimentos para uma questão. O caso em si teria, nesta situação, uma importância secundária, pois é utilizado como um suporte para facilitar o entendimento da questão. Isso não significa que o caso não seja olhado em profundidade, mas que isto está em função de auxiliar o pesquisador a atingir um interesse externo ao caso.

Um estudo de caso qualitativo exige ainda do pesquisador, segundo Stake (2000), um grande investimento de tempo de pesquisa no local, entrando em contato pessoal com as atividades relacionadas ao caso, bem como refletindo e revisando sua interpretação sobre o que está acontecendo. Este ponto pode ser relacionado de forma clara com o tipo de pesquisa aqui idealizado, uma vez que a escola em questão é alvo do meu trabalho como psicóloga escolar desde 2004, portanto há três anos. Minha relação com a escola é profissional e não pode ser caracterizada da mesma 
forma que uma pesquisa de orientação etnográfica, onde o pesquisador tem um contato com a instituição direcionado pelo seu objetivo de pesquisa. Contudo, existe uma convivência e uma reflexão extensa sobre as relações ali estabelecidas, ainda que a partir de um outro lócus, como profissional e não como pesquisadora. Este material coligido durante este tempo de trabalho será aqui tomado como um elemento de pesquisa, contribuindo para a reflexão sobre o papel do diretor nesta cultura escolar específica. A escolha de um tipo de pesquisa como estudo de caso também vai ao encontro da linha da contradição entre o genérico e o específico, pertinente ao tipo de reflexão aqui estabelecida.

A seguir, apresento uma justificativa para a eleição da escola e do diretor focalizados neste estudo como situação exemplar para a reflexão sobre a influência do diretor na constituição de uma cultura escolar inclusiva.

\subsection{Porque pesquisar a instituição escolhida}

Como foi anteriormente mencionado, o início de meu contato sistemático com a escola José Paulo Paes ${ }^{8}$ ocorreu no início de 2004, quando comecei a atender a escola como psicóloga escolar.

Cabe aqui detalhar como se encontra estruturada esta função. O psicólogo escolar compõe uma equipe multidisciplinar, responsável pela orientação técnica, que também inclui profissionais como fonoaudiólogos, pedagogos, assistentes sociais e terapeutas ocupacionais. A equipe técnica da qual participo trabalha com os quatro anos iniciais do Ensino Fundamental, estando formalmente constituída desde 2000 e contando atualmente com cerca

8 O nome da escola foi trocado, utilizando-se o nome do poeta José Paulo Paes, autor do poema citado na epígrafe da introdução deste trabalho, como uma pequena homenagem. Portanto, a denominação Escola José Paulo Paes aqui referida é fictícia. Os nomes utilizados para as pessoas citadas também são fictícios, de forma a não revelar a identidade dos envolvidos. 
de 30 componentes. As principais orientações da equipe, de acordo com a secretaria de educação, referem-se a atividades de formação e de orientação escolar. Os psicólogos participantes desta equipe buscam privilegiar um trabalho de formação da equipe gestora (que inclui diretor, vice-diretor e professor coordenador), mas existe uma demanda das equipes escolares de focar a discussão em questões individualizadas relativas a alunos, o que acaba fortalecendo a velha polêmica entre encaminhamentos para a saúde ou enfoque pedagógico das questões relacionadas com alunos, envolvendo temas de comportamento ou de aprendizagem. Apesar da equipe de psicólogos ter claro que o foco do trabalho na escola é o processo de escolarização e de ensinoaprendizagem, nem sempre este caminho é claro para as equipes escolares, o que leva a alguns conflitos, mais ou menos expressivos de acordo $\mathrm{cm}$ as concepções educacionais dos envolvidos. Outra dificuldade é que existe uma tendência em delimitar com clareza o papel de cada profissional componente da equipe pela secretaria de educação, que tende a operar com funções atribuídas a cada profissional por aproximações do campo de saber, o que acaba favorecendo uma fragmentação e facilitando a emergência de uma forma clínica de tratar as questões escolares. A expectativa de que o psicólogo vá atuar em questões individuais e de certa forma descoladas do contexto escolar é alimentada também pela direção da área de ensino, que orienta a atuação da equipe técnica. Assim, ao se tratar do tema inclusão, por exemplo, tende-se a atribuir a tarefa ao psicólogo, enquanto no tema alfabetização busca-se o participação do pedagogo. Um dos efeitos nocivos é que diferentes profissionais visitam a escola, com foco em uma ou outra questão a ele atribuída no planejamento da equipe técnica, mas nem sempre estes profissionais têm oportunidade de eleger trabalhos conjuntos e voltados para necessidades mais específicas da escola atendida. O pedagogo exerce o papel principal na equipe: é ele o profissional em maior número (o que possibilita uma maior freqüência de visitas à escola, aproximadamente semanal), e que acumula funções de supervisão além da orientação pedagógica. Ou seja, este profissional discutirá 
ações de formação dos professores, mas também irá conferir documentações e orientar a escola quanto a decisões centrais da secretaria de educação. Nem sempre a parceria do psicólogo com o pedagogo é possível, quer seja por falta de momentos de planejamento conjunto, quer seja pelo direcionamento político de delimitar o campo de ação de cada profissional. Assim, muitas vezes o trabalho do psicólogo na escola acaba focado na tentativa de formar uma parceria com a equipe gestora, cujo tema predominante é a discussão de problemáticas relativas a alunos, enquanto ao pedagogo ficam questões mais coletivas. Apesar das limitações evidentes, algumas vezes são possíveis parcerias interessantes e que visam a escola como um todo, principalmente no que diz respeito a avaliação das necessidades educacionais de alunos e em como a escola lida com a questão da diversidade, orientações do trabalho do psicólogo na escola.

Cada escola tem profissionais de referência na equipe pedagogo, fonoaudiólogo, entre outros. O ano de 2004 foi o primeiro ano em que fui psicóloga de referência da escola José Paulo Paes. Já conhecia o espaço físico por uma visita realizada em 2002, quando trabalhava num projeto de educação ambiental promovido pela mesma secretaria, e fui até lá para fazer uma pesquisa sobre como o tema era explorado na unidade. A escola acabara de ser municipalizada, pois até então havia sido uma escola estadual, atendendo inclusive ao ensino médio. A então vice-diretora levou-me para conhecer o prédio, e minha primeira impressão foi a de um espaço fechado e um tanto sufocante. $\mathrm{O}$ uso de paredes de tijolo e as grades em excesso davam aos ambientes um aspecto "quadriculado", de isolamento. A pintura desgastada e escura das salas de aula e as fechaduras com reforço de placas metálicas nas portas também contribuíram para esta impressão. Havia também uma grande quantidade de mobiliário sem condição de uso estocado em um nicho do telhado, cujas brechas eram invadidas por pombos que sobrevoavam o pátio interno. A escola se compõe de dois blocos interligados, e o acesso se dava 
exclusivamente por via interna, através de um corredor. Minha acompanhante fazia questão de fechar com cuidado as portas de grades que atravessávamos. O dia estava ensolarado e há áreas verdes no entorno, e causou-me estranheza notar que as crianças não circulavam pela parte externa do prédio. Ao questionar a vice-diretora, ela afirmou-me que a comunidade do bairro era problemática e até perigosa, por isso a equipe optou em não utilizar os espaços externos. Na ampla quadra, alguns adolescentes jogavam bola. Perguntei se não havia como organizar o uso dos espaços pela comunidade, possibilidade logo rejeitada pela vice-diretora pelos mesmos motivos alegados. Saímos para andar em torno do prédio escolar, onde a vice-diretora justificava tais medidas mostrando o lixo jogado pelas casas do entorno e alguns cantos que serviam de mictório improvisado. Fiquei com a vívida impressão de que alunos e professores viviam ali numa espécie de trincheira. Também pensei se teria ocorrido aos professores e gestores que a comunidade de quem pareciam se defender com tanto empenho era a mesma que justificava sua existência e ocupava todos os dias aquele espaço no papel de alunos.

A escola foi criada no ano de 1985, época da provável construção do prédio. Atualmente, o primeiro bloco conta com nove salas de aula, distribuídas em três andares, sala de professores, secretaria, uma sala da direção e uma da coordenação, almoxarifado, três banheiros administrativos e dois de alunos e sala de apoio pedagógico. A biblioteca e o laboratório de informática foram construídos em 2005, tendo ambos amplas e modernas instalações. No segundo bloco, encontram-se dez salas de aula, cozinha e refeitório, dois banheiros de alunos, pátio coberto, pátio descoberto com brinquedos de madeira e quadra descoberta. Os serviços de limpeza e merenda são de responsabilidade de empresas terceirizadas. A escola encontra-se sobre um terreno com aclive acentuado, por isso construída em diversos níveis, sendo o acesso feito através de muitas escadas. Recentemente, em 2005, foi construída uma rampa para dar acesso à biblioteca, que é utilizada pela comunidade. Os 
acessos internos do prédio, porém, são feitos através de escadas, apresentando portanto pouca acessibilidade a alunos com deficiência física que façam uso de cadeiras de roda. As classes com alunos com maior dificuldade de movimentação são preferencialmente colocadas no nível térreo, porém o acesso é limitado pela arquitetura interna e externa do prédio.

A escola localiza-se num bairro periférico, com população flutuante e com nível de renda baixo. A maior parte das moradias é de alvenaria, mas muitas resultam de ocupações, como favelas urbanizadas precariamente. As ruas do bairro são estreitas e sinuosas, com sinalização precária. Há pequenos comércios variados, UBS (Unidade Básica de Saúde), creche e biblioteca. A quadra e o parque com brinquedos da escola são utilizados nos fins de semana pela comunidade como alternativa de lazer, apesar de não estarem em bom estado.

Atualmente, funcionam na escola 33 classes do Ensino Fundamental organizadas em primeiro e segundo ciclo (equivalente a $1^{\mathrm{a}}$ à $4^{\mathrm{a}}$ serie) e em dois períodos (manhã e tarde), totalizando 975 alunos atendidos. Trabalham na escola 33 professores, sendo 16 efetivos da rede municipal e 17 conveniados da rede estadual. A escola conta ainda com quatro professores substitutos e cinco estagiários. Ocorrem três turmas de apoio pedagógico, formadas por alunos com dificuldades no processo de aprendizagem (de acordo com a avaliação dos professores), e que funcionam no período contrário ao das aulas regulares. Funcionam à noite duas turmas de educação de jovens e adultos. A escola tem dois HTPCs - Horário de Trabalho Coletivo Pedagógico, às segundas-feiras, no período da tarde (13h às $16 \mathrm{~h}$ ) e da noite (19h às $22 \mathrm{~h}$ ), sendo que do primeiro participam 17 professores e do segundo, 23 professores. Este horário ocorre semanalmente e faz parte da carga horária de trabalho dos professores. Há ainda um horário alternativo às quartas-feiras à noite, onde participam quatro professores que possuem duas matrículas, ou seja, dois 
registros como funcionários da secretaria de educação em períodos diferentes (manhã e tarde), tendo, portanto, que participar de dois HTPCs por semana.

A reputação da escola no bairro não é boa. A Escola José Paulo Paes tem fama de ser uma escola ruim, com maus professores, e até hoje, após muitas mudanças, este é um rótulo difícil de ser revertido.

Ao conversar com a equipe técnica que anteriormente acompanhava a escola, recebi algumas informações. A antiga diretora do Estado estava se desligando da escola por motivo de aposentadoria, mas também após ter passado por um processo administrativo no ano de 2003. A pedagoga que acompanhava a escola relatou questões complexas envolvendo professores da escola e a diretora. Os relatos versavam sobre atitudes inadequadas do ponto de vista pedagógico e administrativo, bem como excesso de faltas de professores e atitudes discriminatórias envolvendo alunos. Um dos casos era sobre uma professora que consumiu um lanche de uma famosa lanchonete de fast-food dentro da sala, em horário de aula e em frente aos alunos, atitude conhecida pela diretora e justificada pela suposta hipoglicemia da professora, que a obrigava a alimentar-se durante o trabalho. Em conversa com a psicóloga que acompanhava a escola antes de mim, os relatos não diferiam muito, predominando atitudes em relação aos alunos de descaso, discriminação e preconceito por parte dos professores e gestores da escola.

Conheci a nova diretora, Cecília, logo na minha primeira ida à escola para fazer minha apresentação, junto com a pedagoga. A diretora Cecília relatou que esta era a sua primeira experiência em cargo de direção, tendo sua experiência profissional como professora, cargo que continuava exercendo em outro município, no período noturno, na educação de jovens e adultos. A impressão inicial foi de uma pessoa com uma postura crítica, consciente das dificuldades que enfrentaria e que estava buscando articular-se com a professora coordenadora e a vice-diretora, também novas na função. 
Logo nos nossos primeiros contatos, a diretora Cecília trouxe algumas preocupações que foram ao encontro das minhas. Numa das minhas primeiras visitas, observei que os alunos não usavam a quadra ou o pátio externo durante os recreios, que se davam em um espaço exíguo e eram extremamente ruidosos. A diretora empenhava-se em vencer as barreiras colocadas pelos professores para o uso dos outros espaços. Lembro-me de ter feito um pequeno croqui com a disposição de jogos nos espaços internos e externos, que foi apresentado e discutido pela equipe de professores. Segundo seu relato, parte do grupo parecia interessada, mas logo foi ficando claro onde estavam as resistências. Os professores desenvolveram um projeto com os alunos sobre como poderia ser o recreio.

Em meus encontros regulares com a diretora Cecília e a professora coordenadora, a questão da indisciplina era trazida como um dos principais problemas. Era recorrente a queixa de que os alunos não permaneciam em sala de aula e ficavam andando pelos corredores. Este tipo de comportamento era até então considerado normal na escola, e começou a ser questionado por mim e pela equipe gestora. Refletíamos sobre em que medida o professor considerava sua responsabilidade em relação ao grupo-classe, que parecia estar vinculada a uma questão mais "geográfica": aluno é aquele que fica dentro da sala de aula. Soubemos também que alguns professores costumavam trancar as salas para que os alunos não saíssem. O hábito de recorrer à direção por conta de comportamentos de alunos era freqüente, sendo que os alunos eram levados e deixados na sala da coordenação ou da direção. Lentamente, a nova diretora começou a limitar este tipo de ação de alguns professores, e logo surgiram as resistências. Durante o ano, Cecília vivenciou alguns embates com professores cuja prática era bastante questionável. Eu também participei de algumas questões, sendo a principal delas uma discussão que efetuei com duas professoras sobre os termos que as mesmas utilizaram para referir-se a um aluno em um relatório, bastante pejorativos. De forma 
geral, eu já havia observado falas de professores indicativas de posturas preconceituosas em relação aos alunos e à comunidade. Em eventuais observações de sala de aula, havia observado a predominância de formas tradicionais de ensino, onde o silêncio era exigido e tido como sinônimo de bom comportamento. Algumas questões envolvendo alunos eram tratadas como se fossem sem solução, como se o aluno fosse alguém "perdido", para quem não haveria salvação ou recuperação. Estas questões eram problematizadas pela diretora Cecília, e a sensação era de estar remexendo em pactos muito bem sedimentados, interrogando acordos que nunca antes haviam sido questionados.

Em relação a alunos com deficiência, não havia na escola nenhum aluno com uma deficiência diagnosticada mais expressiva. Alguns alunos com deficiência auditiva eram atendidos em sala de recursos, também por mim acompanhados. As principais questões trazidas em relação aos alunos eram a já mencionada indisciplina (quadro que estava se revertendo) e questões de aprendizagem, com alguns índices altos de retenção ao final dos dois ciclos, onde a retenção era possível. No mês de setembro, contudo, a escola recebe Gabriel, um aluno com síndrome de Down que, apesar de ter dez anos, nunca havia freqüentado uma escola regular, apenas atendimentos na Apae. Meu primeiro contato feito com a mãe do aluno foi por telefone, e ela me perguntava se devia matricular o filho na Escola José Paulo Paes ou em uma outra escola municipal perto de seu trabalho. Aconselhei-a a visitar ambas as escolas, e a conversar com as diretoras. Alguns dias depois, ela me telefonou e disse que havia decidido matricular Gabriel na Escola José Paulo Paes, pois havia sido muito bem recebida pela diretora e gostado da escola. $\mathrm{O}$ aluno foi bem acolhido na escola, tendo algumas dificuldades de adaptação que foram sendo superadas com o tempo. Iniciei um acompanhamento mais sistemático com a professora, tendo alguns encontros com ela e fazendo observações de classe. A professora de sala de recursos também participou do trabalho, fazendo algumas 
observações e também orientando a professora de Gabriel. Tive reuniões com a mãe e com a diretora, e a escola mostrou-se receptiva a todas as intervenções propostas. A inclusão deste aluno foi tratada como um bom desafio pela escola, e foi acontecendo de forma gradual, através do aumento da sua participação nas atividades escolares e uma crescente segurança da equipe escolar no trato com ele.

O ano de 2004 foi um ano de remoção de professores, o que resultou na saída de alguns profissionais cujas práticas estavam sendo questionadas, por iniciativa própria destes profissionais. Observei junto à equipe gestora que era importante que o grupo construísse uma nova identidade, focada na autonomia e no respeito ao aluno, e tendo como principal objetivo a aprendizagem; daí a importância de deixar claro para todos que esta seria a filosofia predominante na escola. Os profissionais incomodados com esta nova postura teriam sempre a possibilidade de buscar outro local de trabalho mais afeito às suas concepções de educação. A escola mudava de forma evidente, e para melhor.

Contudo, o ano de remoção traria outra questão: a remoção da diretora. Cecília não era efetiva no cargo e, portanto, o cargo de direção na Escola José Paulo Paes iria automaticamente para a remoção, podendo ser escolhida por outro diretor. A perspectiva de interromper um processo de mudanças positivas se desenhava, e cresceu com a notícia de que a Cecília não ficaria na escola, uma vez que outra profissional teve sobre ela prerrogativa de escolha, portanto, a escola receberia uma nova diretora em 2005. Soube por Cecília que a nova diretora que assumiria seu posto fez uma visita à escola, e que ela havia simpatizado com a mesma. Neste momento, só me restava aguardar.

No início de 2005, conheci Marcela, a nova diretora. Assim como da diretora anterior, tive dela uma boa impressão. Marcela relatava ter 
vindo da educação infantil, e não tinha experiências anteriores como diretora. Avaliei como valiosa sua contribuição, trazendo para a escola uma outra perspectiva, no sentido de proporcionar um lado positivo da função da escola a um grupo com experiências de fracasso e muitas dificuldades. Por exemplo, focar questões caras à educação infantil, como a roda de conversa no início do dia e a rotina da sala de aula, como uma forma de resgatar aspectos um tanto esquecidos no Ensino Fundamental, tradicionalmente mais voltado para a transmissão de conteúdos do que formação de atitudes.

O grupo de professores estava mais coeso, com alguns professores que antes não se expunham tomando mais iniciativa após a saída de alguns professores mais resistentes. A vice-diretora ingressou na escola junto com a diretora, mantendo com esta uma boa parceria, pois já trabalhavam juntas. No primeiro semestre a professora coordenadora adoece e se afasta do cargo. Geralmente, a professora coordenadora acaba sendo minha principal interlocutora em meu trabalho com a escola, mas a diretora Marcela sempre fez questão de participar das reuniões, mostrando grande envolvimento com a parte pedagógica da escola. Assim, quando a escola ficou sem coordenadora, a diretora assumiu este papel.

As queixas de indisciplina continuaram, mas em menor escala, tendo a nova diretora mantido tratamento semelhante à questão, ou seja, não mantendo alunos na sala da diretoria e desestimulando que os professores adotassem esta alternativa. As questões de indisciplina foram tomadas também pela nova diretora não pelo viés da culpabilização do aluno e sim pela adequação da gestão de sala de aula. Casos mais complicados, como de Jonas, um aluno com questões de comportamento e familiares mais expressivas, eram discutidas com o grupo de professores, sendo que participei de uma discussão destas, com o foco sempre voltado para a inclusão do aluno e o atendimento a suas necessidades. O professor que estava com Jonas era interessado e participante, envolvia-se com seus alunos e trabalhava com projetos, tendo até 
promovido um mutirão de pintura da sala de aula. Seu trabalho era apoiado pela direção, e o aluno melhorou bastante, mostrando-se mais participativo. Também propusemos um trabalho com a professora da sala de recursos através da linguagem do grafite, visando sua alfabetização, uma vez que Jonas já era um adolescente de doze anos, visivelmente deslocado entre os colegas de menor idade. Ainda que seus avanços fossem pequenos em relação às expectativas da escola, e que ele acabasse se afastando da escola no final do segundo semestre, o investimento feito na sua aprendizagem e as alternativas propostas pela escola para ele sinalizam uma outra orientação da equipe, bem diferente do que era praticado anteriormente, de um esforço conjunto para garantir um bom atendimento a todos os alunos. Mesmo sem ter atingido plenamente as aprendizagens do ciclo, Jonas foi aprovado para a $5^{a}$ série, pois já havia sido retido por duas vezes no $2^{\circ}$ ano do ciclo II. A equipe, contudo, estava segura quanto a essa atitude, pois a repetência não era uma boa solução para Jonas.

A questão da retenção foi outro indicador importante. Desde cedo a diretora problematizou a questão das retenções, prática até então comum na escola, e que também fora problematizada por mim. Este tema passa então a ser debatido e trabalhado na escola, com a finalidade de que a retenção não seja utilizada como uma resposta pedagógica às necessidades dos alunos. Formam-se grupos de estudo de alunos, como estratégia de investimento intenso na aprendizagem. Participo de conversas com professores problematizando a retenção e trago textos teóricos nesta linha de pensamento. Os professores participam, trazem dúvidas e podemos conversar de forma aberta.

Outro indício importante de uma postura democrática da diretora foi a sua receptividade à implantação, em 2005, de uma classe de aceleração na escola. Como integrante da equipe que coordenou o projeto, senti muitas resistências de escolas para implantação destas turmas, algumas veladas 
e outras bem mais explícitas. O início do projeto foi um tanto tumultuado por falta de professores e questões de transporte de alunos, e mesmo sendo consultada em um prazo muito curto a diretora teve uma postura receptiva. A escola foi aberta para a turma de alunos - adolescentes com idade entre 14 e 16 anos, alguns provenientes de classes especiais - desde o início, tomando-os como seus. Houve receptividade e preocupação com a aprendizagem dos alunos. Apesar do projeto ter uma equipe de orientação específica para as professoras participantes, as mesmas foram bem recebidas e integradas na escola, não havendo queixas das professoras em relação à escola, fato que ocorreu em outras turmas, como atitudes discriminatórias, acesso dificultado a materiais, entre outros problemas relatados.

Meu acompanhamento ao Gabriel, o aluno com síndrome de Down mencionado anteriormente, continuou em 2005. A nova diretora também tinha um bom relacionamento com ele, e preocupava-se que ele fosse atendido da melhor forma. Seu caso foi debatido no conselho de classe ao final de 2004, após o que foi decidido que ele deveria permanecer junto com a mesma turma e professora, indo para o segundo ciclo. Ainda que a avaliação feita pela escola sobre suas aprendizagens apontasse que estas estivessem bem aquém das exigidas nesta etapa, foi considerado o conjunto de fatores que melhor beneficiasse o aluno, e não apenas a aprendizagem formal. A professora tinha experiência em educação especial em outra rede, e isso contou para sua escolha. Além disso, a turma contava com uma estagiária para acompanhar o aluno mais de perto, bem como para garantir que a professora pudesse intervir mais individualmente com ele, e a professora de sala de recursos também continuaria o trabalho com o aluno. Em todas as intervenções propostas houve receptividade da escola, mostrando um engajamento na tarefa de incluir o Gabriel. Propus e discuti com a escola a necessidade de registrar a avaliação do aluno no instrumento padrão de avaliação, com as devidas adaptações feitas. Este processo nem sempre contou com receptividade por parte da pedagoga 
que acompanha a escola, uma vez que se estava propondo algo que, embora previsto na legislação federal através da Resolução CNE/CEB n. 2, ainda não estava sistematizado no município. Em nenhum momento tratava-se de algo ilegal; pelo contrário, há regulamentação municipal que oferece possibilidade para tanto, mas trata-se de uma atitude ousada porque pioneira, e que a diretora sempre se mostrou disposta a enfrentar. A mãe de Gabriel também se declarou bastante satisfeita com o trabalho da escola e com a atenção da nova diretora.

Em 2006, meu acompanhamento à escola continuou. A relação com a equipe escolar ficou mais próxima, e a mesma trazia de forma mais explícita suas dificuldades com algumas limitações estruturais, como a falta de um estagiário para acompanhar o Gabriel e os alunos que necessitavam de uma atenção diferenciada. $O$ foco do trabalho de acompanhamento foi o diálogo com professores que trabalham com alunos com necessidades educacionais especiais. Também discutimos, por ter havido uma orientação da secretaria de educação, o encaminhamento de alunos para a saúde, uma questão histórica da psicologia escolar e que se reatualiza de formas diversas.

Neste cenário, propus à diretora entrevistá-la para esta pesquisa, e ela aceitou prontamente. Como motivo para realizar este convite, além da receptividade, abertura à mudança e postura democrática da diretora, que pode ser inferida do relato acima, vislumbro no aprofundamento da análise da prática desta diretora a oportunidade de refletir sobre sua contribuição para a construção e manutenção de uma cultura inclusiva na Escola José Paulo Paes. O que é trazido por ela e que faz a diferença, como constrói sua ação, como intervém, o que seleciona, prioriza e o que busca combater, são aportes que enriquecerão esta discussão e certamente apontarão caminhos. 


\subsection{Pesquisa documental}

Com o objetivo de delinear o contexto onde a escola pesquisada ocorre histórica e socialmente, foi feita uma pesquisa documental em várias fontes oficiais e públicas que delimitam ações para a rede municipal de ensino e para a escola em questão. A pesquisa orientou-se por dois focos: como as atribuições do diretor de escola são colocadas nos documentos, e como os temas educação inclusiva e gestão democrática são tratados. Segue abaixo a relação dos documentos pesquisados, comentados sucintamente:

a. Plano Municipal de Educação: contendo as metas do município para a educação, com itens específicos para o Ensino Fundamental e a Educação Especial.

b. Metas da Educação: publicação anual, compreendendo os anos de 2001 a 2006. Nelas, aparecem diversas metas colocadas para as equipes escolares e técnicas, bem como para os administradores.

c. Proposta Curricular: documento introdutório, onde se elencam os princípios e diretrizes filosóficos da rede municipal de ensino. Entre cinco princípios fundamentais, encontram-se o atendimento à diversidade e a gestão democrática da escola.

d. Regimento Escolar da Educação Infantil e Ensino Fundamental: documento normatizador. A gestão democrática é bastante destacada, com um título dedicado integralmente ao tema. Os artigos que dele fazem parte versam sobre a gestão e o projeto pedagógico da escola, autonomia da escola, constituição e formação do conselho de escola, entre outros aspectos. As atribuições do diretor são explicitadas no item dedicado à composição da equipe escolar. Não há referência explícita à educação inclusiva ou a alunos com necessidades educacionais especiais. No geral, o regimento tem um tom conservador, atendo- 
se ao essencial proposto na LBDEN - Lei de Diretrizes e Bases da Educação Nacional (1996), sem maiores inovações.

e. Orientações pedagógicas e administrativas para o Ensino Fundamental: publicação normatizadora, onde são relacionadas orientações regulamentares feitas às escolas em diversas áreas, como projeto pedagógico da escola, acolhimento dos alunos, grade curricular, planos de formação da unidade escolar, conselhos de escola e gestão democrática, entre outros.

f. Documentos relacionados à educação inclusiva: relacionam-se aqui três documentos principais, dos anos de 1999, 2005 e 2006. Os documentos são detalhados, abordando desde princípios filosóficos até a descrição dos apoios oferecidos, avaliação das necessidades educacionais especiais, centros de apoio, entre outras temáticas. Revelam uma preocupação com o tema, tratando-o de forma minuciosa e atenta.

De forma geral, pode-se observar na análise dos documentos uma preocupação da secretaria de educação com a educação inclusiva, ora de forma mais implícita, ora de forma explícita e por meio de ações objetivas. Ainda que algumas ações sejam descontínuas, a presença do tema educação inclusiva é constante.

Observou-se a partir da análise uma progressiva transferência de responsabilidades, inicialmente focadas em ações de Educação Especial, para as áreas de ensino. A preocupação inicial com ações de diagnóstico e encaminhamento é paulatinamente dividida com as escolas, através de documento orientador para encaminhamentos aos apoios, não ficando uma decisão centralizada apenas em pareceres das equipes técnicas. É explicitada também o foco da avaliação das necessidades educacionais especiais a partir de indicadores pedagógicos, e não clínicos. 
Aparece o aumento gradual de recursos destinados a implantação da educação inclusiva, como recursos para acessibilidade e tecnologia assistiva, previstos e enunciados nas metas. A preocupação com a articulação entre os diferentes setores e equipes envolvidas também é constante, bem como a preocupação com a formação dos profissionais envolvidos.

\subsubsection{Projeto pedagógico da escola}

Neste item, pretende-se analisar de forma breve os documentos dos Projetos Pedagógicos da escola dos anos de 2003, 2004 e 2005 quanto às referências aos temas educação inclusiva e gestão democrática. É importante destacar que em cada ano a escola contou com uma diretora diferente, sendo que no ano de 2005 assumiria Marcela, a diretora atual. Este é um aspecto importante, pois a responsabilidade pela elaboração, execução e avaliação do Projeto Pedagógico da escola é atribuição do diretor, segundo o regimento escolar. Deduz-se que sua influência no mesmo é expressiva, e que sua orientação mais ou menos democrática, mais ou menos inclusiva, poderá ser percebida nas "entrelinhas" do Projeto Pedagógico.

a. Projeto Pedagógico 2003

Neste documento, quando a escola ainda era de responsabilidade do Governo do Estado, não se encontra menção à questão do atendimento a alunos com necessidades educacionais especiais, ou previsão de algum apoio específico para alunos com deficiência. Também não há referência à acessibilidade física do prédio escolar.

Das treze metas propostas para o ano, sete referem-se a questões de trabalho do professor, como "aumentar para 100\% o número de 
professores pontuais" ou "conseguir que 100\% dos professores avisem com antecedência a falta ao trabalho e deixem atividades com o professor substituto", o que é um provável indicador de relações difíceis entre gestão e professores.

O tom é tradicional e alguns trechos soam discriminatórios, como os que se referem à comunidade atendida: "faixas sociais mistas na seguinte proporção: 30\% remediados, 35\% pobres, $35 \%$ miseráveis, $45 \%$ vivem em agrupamento familiar ou família desmembrada". As questões de comportamento apresentadas pelos alunos são atribuídas às suas condições sociais, ou supostas carências afetivas:

Nossos alunos são, na maioria (65\%) carentes de afeto, de atenção, com história de vida muito sofrida. Sem expectativa de futuro, autoestima baixa, ao mesmo tempo que buscam na Escola o que não têm fora dela, refletem as carências no comportamento: dificuldades de concentração e organização; agitados; são agressivos, na medida em que resolvem seus conflitos agredindo verbalmente e/ou fisicamente os seus "supostos" adversários [...]; têm dificuldades de seguir regras e acatar ordens; faltam muito; não se respeitam e têm dificuldade de reconhecer e respeitar o outro (p. 17-18).

Sobre o conselho de ciclo bimestral, são colocados os objetivos de avaliar, decidir e homologar. O item "avaliar" refere-se ao rendimento da classe e à conduta da classe, que é feita "confrontando o relacionamento da classe com o professor, identificando os alunos de ajustamento insatisfatório à atuação da classe e da escola, propondo medidas que visem ao melhor ajustamento do aluno" (p. 32).

$\mathrm{Na}$ avaliação da proposta pedagógica e do plano de gestão, aparecem como não tendo sido atingidas metas como melhorar a disciplina dos alunos em classe e demais dependências, reduzir a reprovação e a evasão, e a pontualidade do professor. Na avaliação do corpo docente sobre 
2002, aparecem apontados problemas como alto índice de absenteísmo e evasão, e formação de classe cuja composição procurou contemplar problemas de comportamento de alunos através do agrupamento em uma única turma.

Os exemplos são muitos. De forma geral, o perfil que é possível apreender da leitura do documento é o de uma escola tradicional, fortemente hierarquizada, com profissionais pouco envolvidos e uma prática alheia às necessidades dos alunos atendidos.

b. Projeto Pedagógico 2004

O documento deste ano adota uma orientação diferente. São colocados objetivos relacionados aos os pais e comunidade, como "conhecer as expectativas da comunidade, suas necessidades, valores, problemas que enfrentam e, através deste conhecimento, poder atendê-las e auxiliá-la a ampliar seu instrumental" e "abrir o espaço da escola para a participação da comunidade" (p. 4). Nos objetivos relativos a professores, aparecem "contribuir para o processo de formação permanente da equipe" e "valorizar cada profissional, elevando seu potencial como pessoa" (p. 6). Nos objetivos junto aos alunos, estão "estimular a participação e o envolvimento dos alunos nas decisões da escola" (p. 7). A educação inclusiva aparece como uma ação a ser desenvolvida para melhorar a qualidade de ensino, bem como a gestão da escola entendida como um processo democrático (p. 8). A orientação é claramente mais democrática e humana.

Nos anexos, aparece um projeto visando a comunidade escolar e do entorno intitulado "Vivendo e refletindo valores na escola", com a finalidade de responder às questões de indisciplina e desrespeito apontadas. Valoriza a diversidade cultural e aponta princípios como "exemplos formam mais do que palavras" e "aquilo que ressaltamos cresce, seja algo de bom ou 
ruim" (p. 44-45). Propõe ações a serem desenvolvidas nos diferentes anos/ciclos através de literatura, vídeos e músicas, entre outras. Percebe-se que a escola, a partir da identificação de uma situação, não se contenta em buscar culpados e procura propor algum tipo de ação, passando pela valorização dos envolvidos.

c. Projeto Pedagógico 2005

Logo no início do documento, na caracterização da escola, é apontado o problema da acessibilidade do prédio: “a característica estrutural que interfere na rotina e no atendimento da diversidade é a falta de acessibilidade para pessoas com necessidades especiais, pois a construção é antiga, prédios de três andares com vários lances de escadas, sem banheiros adaptados e sem rampas de acesso entre os espaços internos e externos da escola" (p. 2-3). O texto prossegue defendendo a construção de um "ambiente escolar humano e fisicamente acolhedor", apontando a necessidade de reestruturação e reforma.

Ao caracterizar a comunidade, relata-se que "muitas famílias não são constituídas de maneira estruturada conforme os padrões da sociedade. São agrupamentos de pessoas que moram na mesma casa, geralmente em condições precárias e com historias de vida marcadas pelo sofrimento" (p. 7). O texto revela uma preocupação em estabelecer uma relação mais próxima e empática com a comunidade, reiterada ao falar dos alunos, ao apontar que

essas crianças lutam pela própria sobrevivência e trazem para a escola o conhecimento informal, pois vão e voltam para a escola sozinhas com a autorização por escrito dos pais, andam pela cidade, brincam nas ruas, freqüentam a praça [nome da praça localizada no centro da cidade], assistem TV, jogam video-game etc sem ter um limite de horário (p. 7). 
Nos objetivos da escola, aponta-se a questão da disciplina, alto índice de alunos não alfabéticos, repetência, problemas estruturais e descrédito da comunidade como situações atuais a serem superadas. Busca-se uma escola democrática, organizada, de qualidade, aberta à comunidade e com melhores indicadores de alfabetização e aprovação. Para tanto, são propostas a democratização de decisões, acolhimento da comunidade e participação dos pais, formação e reflexão da prática, entre outras ações. $\mathrm{O}$ atendimento à diversidade é destacado, sublinhando-se a importância de "oferecer caminhos diversos, atividades diversificadas, olhares diferentes, propostas e intervenções especificas para atender a todos" (p. 11). O atendimento à diversidade é destacado como meta pedagógica.

Os planos de ação das professoras de recursos das áreas de deficiência mental e deficiência auditiva que atuam na escola aparecem anexados ao documento, bem como o plano do apoio pedagógico. Projetos e atividades seqüenciadas com gêneros literários, envolvendo atividades nos dois ciclos e integradas com a educação de jovens e adultos também constam do documento. Aparecem também a aplicação das verbas recebidas e o destaque ao papel do conselho de escola.

De forma geral, a mudança de orientação iniciada no ano anterior permanece e é reforçada, apresentando-se de forma mais organizada e completa. Assim, pode-se cogitar que a presença de um diretor preocupado com a democratização escolar e a educação inclusiva acaba por refletir-se na escrita do plano pedagógico educacional da escola.

Após a análise documental passou-se na seqüência para a entrevista, discutindo seus objetivos no levantamento de dados para esta pesquisa. 


\subsection{Entrevista}

A entrevista é uma estratégia de obtenção de dados comumente empregada em pesquisas qualitativas, sendo utilizada para "recolher dados descritivos na linguagem do próprio sujeito, permitindo ao investigador desenvolver intuitivamente uma idéia sobre a maneira como os sujeitos interpretam aspectos do mundo" (BOGDAN e BIKLEN, p. 134).

Optou-se pela realização de uma entrevista semiestruturada com a atual diretora para poder realizar uma análise mais aprofundada das suas concepções sobre a educação inclusiva e a gestão democrática de escola. Foi utilizada a análise de conteúdo de Bardin (2002) para levantar e discutir as principais categorias identificadas. No próximo item, a entrevista será analisada e discutida de forma mais detalhada, com o objetivo de tecer relações entre os aspectos notados e a cultura escolar. 


\section{5}

\section{Resultados e discussão}

\subsection{Análise da entrevista}

A discussão dos dados levantados na pesquisa documental será utilizada como pano de fundo para a discussão a ser feita no confronto com os dados levantados na entrevista com a diretora. A partir dessa análise, serão retomadas e aprofundadas as hipóteses iniciais, ou seja, a de que as concepções sobre educação e alguns aspectos idiossincráticos (valores, crenças) do diretor influenciam a forma como a cultura escolar se constitui. Esta questão pôde ser explorado em certa medida na análise efetuada dos Projetos Pedagógicos escolares, e pretende-se agora aprofundá-la.

A entrevista realizada foi do tipo semi-estruturada, com algumas questões propostas colocadas como roteiro dos pontos a serem enfocados. O roteiro proposto e seguido percorreu os seguintes itens:

- Apresentação do objetivo do trabalho: conhecer melhor o papel do diretor escolar na inclusão de alunos com necessidades educacionais especiais [mais especificamente, alunos com deficiência].

- Alguns dados pessoais, como idade, formação acadêmica, etc.

- Resumo da história profissional na educação (atuação como professora) e como diretora. Experiência com alunos 
com necessidades educacionais especiais quando professora.

- Expectativas ao assumir a direção da escola. Confronto entre as expectativas e o que encontrou efetivamente.

- $\quad$ A eleição de prioridades de trabalho.

- A experiência de dirigir uma escola com alunos com necessidades educacionais especiais.

- O processo de atribuição de classes e escolha dos professores que trabalharão com alunos com necessidades educacionais especiais.

- Experiências que considera ilustrativas e ache interessante relatar.

- A prática da gestão da escola em termos de interação com os diversos órgãos colegiados (conselho de escola e APM).

$\mathrm{Na}$ ocasião da entrevista, foi feito um contrato com a diretora sobre posteriores revisões conjuntas a serem feitas da transcrição da entrevista. As etapas previstas da revisão foram a gravação da entrevista inicial, seguida da transcrição da mesma e leitura conjunta para revisão. Foi discutida a possibilidade de uma segunda entrevista, caso fosse necessária, bem como possíveis desdobramentos como a sugestão de outro entrevistado, se fosse o caso. Após a revisão inicial, seria feita a transcrição final da entrevista, e na seqüência a análise e escrita do texto da dissertação, que posteriormente seria lido e discutido, antes da publicação final. 
Na primeira revisão conjunta, a diretora fez observações sobre a linguagem oral transcrita, ficando-se combinado que a fala seria transcrita de acordo com a linguagem escrita convencional.

Foram destacados alguns focos norteadores para a análise,

listados abaixo:

- O que no discurso da diretora mostra como a cultura escolar é hoje?

- O que nesta cultura relatada indica o tratamento que a educação inclusiva recebe?

- É possível perceber alguma relação entre fatores pessoais da diretora e a cultura escolar? (como fatores pessoais, considera-se aspectos da sua trajetória profissional, motivos, valores e aspirações, concepção de educação, sua forma de atuação na escola junto aos professores e demais profissionais, as contradições presentes, sua história pessoal de relação com a educação inclusiva e com a gestão democrática do ensino).

- É possível estabelecer, pelo material analisado, relações entre concepção de educação inclusiva e gestão democrática?

Passou-se a seguir à análise da entrevista, por meio de uma leitura criteriosa em busca das temáticas emergentes na fala da diretora. Como subsídio teórico para esta leitura utilizou-se a análise de conteúdo proposta por Bardin (2002, p. 42). Segundo esta autora, a análise de conteúdo pode ser definida como "um conjunto de técnicas de análise das comunicações visando obter, por procedimentos, sistemáticos e objetivos de descrição do conteúdo das mensagens, indicadores (quantitativos ou não) que permitam a 
inferência de conhecimentos relativos às condições de produção/recepção (variáveis inferidas) destas mensagens".

A autora propõe ainda que se faça uma "leitura flutuante" do texto, num conceito similar ao de atenção flutuante na psicanálise, de forma a possibilitar a emergência dos temas para análise. Cabe aqui destacar a definição de tema e de análise temática para Bardin (2002, p. 105), segundo a qual "tema é a unidade de significação que se liberta naturalmente de um texto analisado segundo certos critérios relativos à teoria que serve de guia à leitura. $O$ texto pode ser recortado em idéias constituintes, em enunciados e em proposições portadores de significações isoláveis. (....) Fazer uma análise temática, consiste em descobrir os "núcleos de sentido" que compõem a comunicação e cuja presença, ou freqüência de aparição podem significar alguma coisa para o objetivo analítico escolhido".

A partir da leitura, foram levantados alguns temas que serão discutidos a seguir. Após esta discussão, buscou-se entre estes temas uma unidade de significado que pudesse ser destacada e então relacionada com os focos de análise propostos, que será detalhada oportunamente. Propõem-se então dois momentos distintos de análise da entrevista. Passemos a eles.

\subsection{Primeiro momento: temas emergentes da entrevista}

São destacados aqui cinco temas emergentes da análise da entrevista.

\section{a. Trajetória profissional na educação}

Marcela descreve seu trabalho na educação como motivado pelo acaso, uma vez que inicialmente aspirava ser engenheira 
química. A impossibilidade de perseguir este desejo inicial deveu-se a uma limitação financeira, o que levou-a a fazer o magistério em escola pública e daí ir "se apaixonando" pela profissão:

Meu irmão na época tinha que pagar colégio, e minha mãe não conseguia pagar para os dois filhos. Tentei então o vestibulinho e passei para o magistério. Quando comecei a fazer magistério fui me apaixonando. Dei aula na educação infantil, no Estado, no Sesi para adultos, na prefeitura de [município vizinho]...

A história da iniciação profissional de Marcela não é diferente da de muitas professoras, que acabam tendo no magistério uma opção mais acessível do ponto de vista econômico e também para um início profissional precoce. Marcela começou a dar aulas em 1988, contando então com 19 anos de idade, tendo sua trajetória escolar sempre como professora em sala de aula. Após o magistério, ingressou na faculdade de Pedagogia em Sorocaba, cidade para a qual havia se mudado, e continuou dando aula, tendo iniciado sua carreira nesta cidade, numa escola estadual. Sua preferência profissional era pelas séries iniciais do ensino fundamental, destacando o trabalho com alfabetização.

O concurso para diretora foi prestado em 2002, segundo seu relato, sem maiores expectativas, e causou-lhe surpresa ter passado entre os primeiros colocados. A aprovação no concurso levou-a a uma decisão difícil, a de abandonar a sala de aula:

Eu fiz o concurso, mas não tive ânsia de ser diretora, nunca pensei "vou fazer Pedagogia porque eu quero ser diretora". Quando me chamaram fiquei muito em dúvida, porque eu amo a sala de aula e o contato com as crianças. Tanto que hoje, na escola, uma coisa que eu prezo muito é a parte pedagógica, eu não consigo me desligar da parte pedagógica. 
Marcela trabalhava em [município vizinho] como professora de primeira série e na rede municipal pesquisada em educação infantil, como professora da turma de 6 anos, e pediu exoneração de ambos os cargos para assumir como diretora. Ao ingressar na rede municipal, no segundo semestre de 2004, assumiu inicialmente uma creche por seis meses, fazendo sua opção definitiva na ocasião da remoção, ao final de 2004, quando escolheu a escola José Paulo Paes.

A trajetória profissional e vida pessoal é aqui destacada como um sub-tema devido ao aparecimento de referências a aspectos da trajetória pessoal de Marcela influenciando suas escolhas profissionais. Foi mencionado anteriormente a questão financeira familiar que a fez a optar pelo magistério. Destacam-se também sua mudança para Sorocaba, ao final do magistério, onde cursou Pedagogia, e o retorno ao município pesquisado, onde nasceu, devido ao fato de ter se casado, exonerando-se como professora estadual.

Com a mudança, passou a dar aulas na prefeitura de [município vizinho], no Estado e no SESI, à noite, na alfabetização de adultos. Quando ingressou na rede do município pesquisado em 1999, exonerou-se do Estado e saiu do SESI, passando a dar aulas em [município vizinho] e no município pesquisado, situação em que esteve até assumir como diretora em 2004.

Sua colocação no concurso cai em alguns pontos devido a não apresentação do certificado do curso de pós-graduação em fase de conclusão durante sua gravidez:

Eu passei super bem, fui a segunda ou a terceira a fazer mais pontos, mas não entreguei a minha pós-graduação, porque eu estava grávida e precisava terminar. Eu estava com uma declaração, não sabia que tinha que ser o certificado, eu não o entreguei e caí um pouquinho, fui pra $16^{\circ}$. 
Outro aspecto da vida pessoal que influenciou sua trajetória profissional foi o critério de escolha da escola José Paulo Paes:

Eu queria uma escola perto da minha casa em questão de trânsito. Quando eu peguei a [creche onde iniciou como diretora], era muito longe. Eu tenho dois filhos pequenos, que vão na escola, tudo. Quando eu fui escolher, havia mais dez escolas além do José Paulo Paes, mas eu queria próxima. Tinha a [nome da escola] com 60 salas, mas eu falei não, aí também não dá, e era muito próximo da minha casa, muito pertinho assim não vai dar certo. Também tinha a [nome da escola], uma diretora escolheu na minha frente. Então, das minhas opções sobrava o José Paulo Paes [...].

Assim, as opções de Marcela foram se delineando em função de sua vida pessoal. Esta é uma realidade a ser considerada com certa freqüência por mulheres educadoras, e também foi vivenciada por Marcela. Os motivos da escolha desta escola, contudo, mesclaram-se entre fatores pessoais (proximidade de casa) e profissionais (tamanho da escola).

Como aspiração profissional, Marcela relatou que pensa em sair da escola José Paulo Paes para uma escola de educação infantil, devido à sua afinidade com o trabalho com a faixa etária. Contudo, considerou esta uma opção difícil:

Eu penso [na remoção para uma escola de educação infantil], se eu
puder, se tiver uma escola, mas é muito difícil, porque sair daqui onde
estou, onde a gente já está construindo um percurso... Dificuldade tem
em todos os lugares, sair daqui onde eu conheço a comunidade, já
tenho uma relação estabelecida com os professores, conheço os
problemas, só se for... A escola aqui não é tão grande em vista do que
tem por aí, em termos de sala de aula está na média. Então...

Parece que, assim como não esperava enveredar profissionalmente para o magistério, o percurso de Marcela como diretora de 
uma escola de Ensino Fundamental a envolve, trazendo desafios e conquistas que acabam por se estabelecer como uma opção mais definitiva.

\section{b. Uma escola rotulada: levantando expectativas}

Este tema refere-se às expectativas levantadas pela escolha da escola José Paulo Paes, bem como as primeiras informações que Marcela obteve, configurando a nosso ver uma escola rotulada. Marcela percebeu esta estigmatização, e buscou abrir brechas num discurso aparentemente consolidado:

Ninguém queria que eu viesse pra cá. A babá que trabalha comigo me disse "aquela escola? Você é louca". Bom, desafio tem em qualquer lugar [...]. Esta é uma escola, uma comunidade carente, uma escola difícil, que já tinha um rótulo. Quando eu escolhi, todo mundo achava que ia ser uma das últimas escolas a ser escolhida, todo mundo se espantou, eu não entendi o porquê, pois estava no infantil.

Nos primeiros contatos as dificuldades foram trazidas para Marcela, formando um painel amedrontador:

Um dia eu vim aqui conhecer a escola e a diretora, elas estavam em conselho. Aí a pedagoga da equipe técnica falou assim pra mim, "ouve um pouquinho o conselho, aí você já vai se apropriando". Quando eu vi aquele monte de aluno na quarta série que já tinha repetido, elas falando sobre problema de indisciplina, pensei: vou ter que chegar lá e arregaçar a manga, porque... como é que eu vou lidar com isso? Eu fiquei as férias inteiras com essa expectativa: alunos não alfabéticos, alunos com problemas de alfabetização, alunos multirepententes. Também soube que o grupo era muito difícil, a direção estava com muitos problemas com alguns professores com relatório. Eu vim aqui e fiquei apavorada, acho que eu vou sair daqui e o primeiro concurso de professor que tiver [risos], sabe, não quero mais brincar disso. 
No entanto, Marcela refletiu sobre as dificuldades, e elaborou uma estratégia de trabalho: conquistar os professores.

\footnotetext{
Haviam muitas, muitas expectativas. Os problemas haviam sido pontuados, então quando cheguei aqui em fevereiro eu já sabia mais ou menos o que estar fazendo. Bom, minha primeira ação vai ter que ser conquistar o grupo, porque se eu não tiver o grupo do meu lado eu não vou ter nada. Nada. Então, eu vou esquecer tudo e vou conquistar o grupo.
}

Desta forma, Marcela conseguiu sair da paralisia inicial. A relação com o grupo foi um dos fatores mais determinantes do seu contato positivo com a escola, e será aprofundada oportunamente.

\section{c. Relação com a educação inclusiva na trajetória profissional}

Este tópico é talvez o mais importante em vista dos objetivos deste estudo. Marcela atribuiu às suas experiências profissionais o contato inicial com a questão da diversidade:

Em [município vizinho] eu dava aula no fundamental, na primeira série, e no Sesi trabalhava com alfabetização de adultos. Eu trabalhava em firmas, dava aula na [nome da empresa], na [nome da empresa], e já tinha que ter um jogo de cintura para atender a diversidade, pois tinha desde a pessoa idosa até aquele molecão [...] você tinha que estar atendendo, tinha que ter um olhar bem apurado.

Como professora, teve sua primeira experiência com uma aluna com deficiência ao trabalhar com uma turma de primeira série em [município vizinho]:

Tive uma aluna, inclusive eu estava grávida do meu primeiro filho. Ela tinha rubéola congênita, ela nasceu quando a mãe tinha... não, não é isso, a mãe dela teve rubéola durante a gestação dela, então ela 
nasceu totalmente comprometida, era uma coisa assim de louco, ela saía do banheiro com a calcinha abaixada, já estava mocinha, eu tinha na época uma primeira série.

Pode-se supor por esse relato as dúvidas e angústias que deviam cercar seu trabalho com esta aluna, gerando bastante ansiedade. $\mathrm{O}$ apoio ao professor oferecido pela escola ou pelo sistema educacional era inexpressivo e insuficiente:

Em [município vizinho], a concepção de inclusão estava começando. Eles não tinham uma formação, simplesmente colocavam as crianças lá, sem redução de sala. [...] Tinha só especialista, psicóloga que passava assim a cada mês, nem entrava na sala. Não havia uma discussão sobre a inclusão, sobre como receber essa criança, esse tipo de orientação não havia.

Pode-se presumir a expectativa de algum tipo de orientação mais próxima, mas sem atendimento. A solidão desta posição experimentada enquanto professora é destacada na fala de Marcela:

Foi o ano todo assim, pesquisando sozinha o que eu podia fazer por ela. A mãe dela também era muito carente, de informações, de recursos, em todos os sentidos. Então eu mesma, do que eu achava que contemplasse pela experiência que tinha [...] eu me sentia completamente despreparada.

Diante da situação, Marcela mobilizou recursos pessoais, como a pesquisa do que propor à aluna, mas também recorre à diretora da escola, lembrando a responsabilidade da escola enquanto um grupo no trabalho com a aluna, o que parece levar a encaminhamentos mais efetivos:

Até que teve um dia que eu tive que chegar para minha diretora e falar que ela não era só minha aluna, ela era aluna da escola. Porque ela saía pelo pátio, não tinha noção do horário, eu tinha que sair correndo atrás dela e você não sabia quem você protegia, quem você olhava, ou as crianças que ficavam sozinhas... Aí a partir dessa 
solicitação que fiz pra diretora é que começaram umas discussões na escola, e eu comecei a ter apoio da direção nesse sentido, pois até então eu nunca tive apoio nenhum por parte da direção, de ninguém.

A constatação de que a aluna não era responsabilidade isolada de Marcela, mas da escola como um todo, é muito importante quando se considera o que deve caracterizar uma escola inclusiva, como apontado por Sage (1999). Nessa concepção de educação, os alunos devem ser considerados como projetos da escola, e não como fardos que acabam sendo atribuídos aos professores que têm menos condições de evitá-los, como aqueles recémingressantes na carreira e que portanto não têm prerrogativa de escolha. $\mathrm{O}$ trabalho pedagógico numa concepção inclusiva é fundamentalmente um trabalho coletivo.

O dilema que muitos professores vivem na tarefa de incluir um aluno com necessidades educacionais especiais é muitas vezes expresso no conflito entre o trabalho com o aluno em questão versus o trabalho com os demais alunos. Este dilema é expresso na fala de Marcela:

Eu comecei a discutir uma coisa que me incomodava: que inclusão era essa, que incluía uma e excluía os 29? Porque eu tinha 29 alunos para serem alfabetizados.

A possibilidade de olhar o grupo como um todo, como 30 e não 29 mais 1, é um dos grandes obstáculos para o trabalho com a educação inclusiva. Para enfrentá-lo, é necessário questionar qual o tipo de proposta pedagógica de aprendizagem a escola está oferecendo. Esta é uma tarefa que dificilmente pode ser enfrentada por um professor de forma isolada de seu grupo, como a própria entrevistada bem colocou, uma vez que o próprio currículo precisa ser problematizado. A situação relatada por Marcela aponta para esta vivência de isolamento, de uma falta de discussão coletiva e que acaba por resultar na presença física do aluno na sala de aula, sem a possibilidade de uma oferta pedagógica mais condizente com a aprendizagem. Marcela é 
testemunha e autora de etapas que precisam ser percorridas na construção de um sistema educacional inclusivo. A discussão, ao ser levada para o grupo de professores, produziu alguma mudança, ainda que incipiente:

Aí nós começamos a fazer algumas ações que contemplassem, que não discriminassem a [aluna], mas considerando que ela não era só a minha aluna, que ela era aluna de todas. [...] Ela não ficava sentada. Se tivesse alguém com música lá no pátio ela queria ir lá, porque para ela era muito mais interessante lá do que a sala de aula. Então nós fizemos alguns combinados que quem estivesse mais na parte externa da escola, nas áreas mais livres, se ela aparecesse, a incluiriam nas atividades. [...] Só que foi a única ação que teve. E aí ela começou a se acomodar.

A mudança foi inicial, e talvez se houvesse uma diversidade na proposta a aluna não tivesse se "acomodado". Na verdade, a acomodação é de ambos os lados, professores e aluna, e a mudança não vem para questionar uma organização escolar ou uma proposta pedagógica, mas para acomodar uma situação complexa. Segundo Marcela, a motivação da diretora e das colegas estava influenciada pelo fato dela estar grávida, havendo, portanto, desejo de ajudá-la pessoalmente. A prática pedagógica, nas discussões de conselho de classe, não era pensada, e não havia uma discussão sobre adaptação curricular. Os ganhos, se houveram, não foram intencionais. Ainda assim, a idéia, pensada na sua positividade, remete às possibilidades que uma ação coletiva pode desencadear nas práticas escolares. Ao avaliar o trabalho feito com a aluna, Marcela admite que

A gente começou a estabelecer algumas prioridades, o que ia estar avaliando dela. [...] Nessa parte, de socialização, aquilo que nós fizemos melhorou a rotina dela para ela, mas não tinha nada... assim, ela não tinha coordenação, só esta parte mesmo da oralidade, da socialização. [...] Quando ela começou a ter um outro olhar do grupo ela avançou com certeza, para ela ficar na sala de aula era muito difícil, então quando ela vinha e ficava aqueles 20 minutos, meia hora, 
uma hora que ela queria ficar era proveitoso, de uma maneira ou de outra ela participava das atividades, porque era interessante para ela. Era respeitar o tempo dela, não adiantava deixar ela entre quatro paredes.

Mesmo com alcance limitado, é possível perceber a possibilidade de refletir sobre outras necessidades que a aluna manifestava e poderiam ser contempladas no espaço escolar.

Na posição de diretora, contudo, Marcela terá de adotar uma perspectiva diversa da até então vivenciada como professora, uma vez que as necessidades do aluno serão a ela colocadas de forma indireta, através do professor, em seu trabalho e demandas. Esta questão é exemplificada por ela ao tratar da situação do Gabriel, o aluno com síndrome de Down, e a forma como percebeu, ao chegar, que a escola e a professora lidam com ele:

Com o Gabriel era mais a ação com a professora, estar conversando, da escola estar vendo ele não como uma criança diferente, mas uma criança com necessidades especiais. Que em certo momento, o Gabriel podia ficar no pátio, mas em outro não era a hora dele ficar. [...] No começo ele ficava muito trancado na sala, literalmente a professora trancava a sala dele, [...] ela passava a chave porque ele fugia, e isso me incomodava. Aí eu comecei a conversar com ela. No começo, claro, eu não cheguei falando, mas aos poucos fui colocando que isso me incomodava, que ele tinha que se apropriar do espaço e os outros alunos tinham que entender, que às vezes ele saía mais por uma necessidade dele, que no começo ele ia até estar saindo, mas que isso ia ser trabalhado no devido tempo com ele. Tanto que hoje o Gabriel fica na sala, uma gracinha, mas foi uma conquista, o que é diferente, é o tempo dele, é um outro ritmo. A gente teve que fazer um trabalho junto com a professora [...] e com as crianças também, para aprender a respeitar o tempo dele, que o tempo dele não é o mesmo tempo deles.

Este é um momento em que a experiência docente de Marcela aparece na forma como intervém junto à professora. A necessidade de 
possibilitar o acesso ao espaço da escola e de oportunizar que o aluno tenha seu tempo respeitado para interagir e perceber a rotina do uso de espaço também é algo a ser destacado. Uma interpretação possível é que sua experiência docente a aproxima das dificuldades vividas pela professora, possibilitando um olhar que leve isso em consideração, agora no papel de diretora. As regras do uso do espaço admitem flexibilização, portanto a escola admite outras possibilidades de ação. Marcela destaca também a importância que dá ao trabalho com os outros alunos da turma, para que percebam e respeitem as diferenças. Com o tempo, o aluno pôde permanecer espontaneamente e por maiores períodos na sala de aula, como algo conquistado e não imposto.

A aprendizagem de Gabriel relacionada a conteúdos escolares, no entanto, não é trazida como uma preocupação na fala de Marcela, que aborda mais a questão da inserção do mesmo no espaço escolar, portanto, com destaque em conteúdos atitudinais. Ao falar sobre a avaliação, no entanto, pode-se perceber indicações de uma preocupação em adequar objetivos e desafios ao aluno, realizando adaptações nas atividades propostas:

A professora faz a avaliação em cima daquilo que ela se propôs a trabalhar com ele. Então a gente conversa, traça os objetivo para cada bimestre daquele aluno, de acordo com aquilo que a gente sabe que ele vai estar correspondendo. A gente trabalha e é feita a avaliação em cima dos objetivos propostos para ele.

A continuidade com a mesma professora, ou com a turma no ano seguinte, também é avaliada, considerando-se as necessidades do aluno, sua maior dificuldade de adaptação a mudanças e outros fatores.

Ele continuou com a professora esse ano. Por quê? Porque eu sei que a adaptação do Gabriel é mais lenta. Não que ele não vá se adaptar com outra sala, que ele não vá se adaptar com outro professor, ele vai. Mas porque eu vou quebrar um processo, vou fazer ele se adaptar novamente, demorar aí três, quatro meses para se adaptar, se ele pode continuar com a professora dele e ganhar esse tempo a favor dele? 
Não que ele não tenha que passar por isso, por essas experiências também, que é legal, mas naquele momento nós avaliamos que para o [aluno] não seria bom mudar de professora, ele vinha num percurso de avanços, se a gente interrompesse... Porque a própria mudança de sala para ele foi complicada, de espaço físico, ele estava num prédio e mudou pro outro, isso já foi muito complicado pra ele. Questão de mudança de horário, de recreio, de rotina já foi complicado, agora imagine agregando isso à mudança de grupo e de professora?

A avaliação do aluno se dá, portanto, com um olhar mais abrangente, considerando particularidades, mas também sua relação com o contexto escolar, e ainda com o professor.

A participação do professor na recepção de alunos com necessidades educacionais especiais em sua sala e o processo de atribuição é trazido por Marcela como algo a ser abordado com o grupo de professores, indicando sua atuação como facilitador do processo de inclusão, como apontado por Glatter (1995), Sage (1999) e Mantoan (2001). Para ela, esta escolha não pode ser imposta, e sim resultar de um investimento formativo por parte da equipe gestora com os professores. Mais uma vez, a experiência como professora serve de referencial para Marcela ao avaliar a continuidade ou não de um aluno com um professor em outro ano:

Eu sei por mim, pela experiência que tive, para o professor também é desgastante. Então a gente avalia o lado profissional, porque você querendo ou não entra com a emoção, e chega uma hora que você também chega no seu limite. Então eu considerei com as professoras [...] se elas estavam dispostas a continuar, porque também não podia ser uma imposição nossa. Nós avaliamos enquanto [equipe gestora] que seria uma boa elas darem continuidade, mas antes da gente fazer qualquer coisa nós vimos as limitações delas, se elas iam dar conta, se era produtivo pra elas enquanto professoras - porque elas também têm que dar conta dos outros, se isso não ia interferir na rotina dos outros, avaliando o professor. Como elas tiveram suporte da escola como um todo, o grupo sempre tem um olhar para elas, [...] então nós 
analisamos isso, como seria para o professor e para a criança. [...] Porque quando tem um querer, eu acho assim, o professor tem que abraçar a causa. Quando tem esse querer as coisas acontecem de maneira mais suave, porque você tem que se envolver com o trabalho, e para você se envolver você tem que ter esse querer. Então nós analisamos isso. [...]

Porque eu preciso confiar que o professor vai estar trabalhando bem com essa criança, [...] tenho que me certificar que aquela criança não pode ficar... do lado, que o trabalho vai ser realmente realizado, que ela não vai ser só mais um aluno na sala, que passa o tempo e vai embora. Mas as professoras que estavam com os alunos de inclusão, todas elas quiseram continuar. $\mathrm{O}$ que foi legal que este ano, quando chegaram os alunos com necessidades especiais e até com deficiência, [...] que já sabíamos que viriam, já começamos esse processo de discussão com o grupo, de quem vai querer ficar. E assim, nenhum foi imposição, todas elas foram assim.

A preocupação com a qualidade do trabalho do professor e portanto, com a qualidade do processo ensino-aprendizagem que o aluno estará vivenciando está presente nesta orientação. Também é reiterado por ela o oferecimento de suporte ao trabalho do professor, como uma forma de assegurá-lo quanto às necessidades que surjam no seu trabalho com o aluno. A escolha é um ato consciente, e implica em uma responsabilidade conscientemente admitida. Porém, nem sempre haverá professores que optem para trabalhar com alunos com necessidades educacionais especiais, havendo também o não querer e até mesmo a recusa. Ao ser questionada quanto ao papel da diretora quanto a isso, Marcela entende que:

Acho que aí o papel da gestão é fundamental. Você não vai chegar com isso. Como a gente já sabia que tinha esses alunos com antecedência, a gente foi conversando e discutindo em HTPC sobre essas crianças que chegariam, e assim mais ou menos você vê o perfil do professor, então vai já também fazendo essa sedução. Mas não foi de uma hora pra outra que elas resolveram ficar, foi uma coisa assim, 
que você lançando a semente, vai conversando, mostrando pro professor que ele é capaz, que eles vão ter o suporte, que eles tiveram o nosso suporte. Eles viram assim, o que foi legal, que em nenhum momento o trio de gestão abandonou a [professora do aluno], tipo "é seu aluno, se vira, você e ele na sala de aula". Então quando esses outros alunos chegaram foi tranqüilo também. [...] Aí sim é fundamental o papel do diretor, de estar colocando, não "ah, meu Deus, nós vamos receber um aluno assim"... Se você coloca isso para o grupo, já coloca esse aluno com deficiência como um estereótipo, como um rótulo, como uma carga, aí é claro que o grupo todo... Qual é o seu olhar para esse aluno? Eu acho que isso é importante também.

Neste trecho, Marcela reitera sua preocupação com o fato de que o professor sinta-se apoiado, e também aponta para a importância que o diretor tem na forma como o aluno será trazido e acolhido pelo grupo de professores, se como um desafio positivo ou como um estorvo. A gestão através de exemplos concretos é uma forma importante de convencimento dos professores (GLATTER, 1995). A concepção do diretor acerca da educação inclusiva, portanto, poderá influenciar o grupo de professores de forma fundamental (SAGE, 1999), pois está atuando como formador do grupo de professores (BARROS, 2004). A prática de conversar abertamente sobre os desafios que o trabalho com a educação inclusiva traz mostra uma preocupação em transpor a imagem idealizada da escola e discutir com o grupo as questões reais, o que é um propiciador de transformações efetivas (SEKKEL, 1993). A responsabilidade pelos encaminhamentos pensados para cada aluno é assumida coletivamente, indicando uma forma democrática de gerir as relações do espaço escolar (LIBÂNEO, 2001).

Em relação ao grupo de professores da escola e sua aceitação da educação inclusiva como uma realidade, a diretora afirma que a maior parte dos professores $(80 \%$, segundo ela), é receptiva à idéia, sendo o restante do grupo bem resistente. Afirma que pôde perceber no grupo o delineamento de um perfil dos professores mais resistentes: 
Tem ainda uns $20 \%$ que são bem resistentes, muito resistentes, que são aqueles mais antigos, que acham que não vão dar conta. [...] São professores mais antigos, que estão prestes a se aposentar, que têm resistência ao novo, aqueles professores que trabalham de uma maneira tradicional, que nivela. Você vê na própria prática, que trata todo mundo igual, que tem uma comanda para os trinta... Agora, um professor que você vê que trabalha com atividades diversificadas na sala, que tem uma prática de trabalhar com três comandas ao mesmo tempo na sala, para este professor é tranqüila essa questão da inclusão.

A disponibilidade do professor para uma flexibilidade em sua forma de trabalhar estaria diretamente relacionada com a sua capacidade de incluir alunos com necessidades educacionais especiais. Um professor aberto ao novo, receptivo aos conhecimentos prévios dos seus alunos, consciente de sua participação em uma sociedade em mudança, cujas estratégias são os projetos e o incentivo a uma atitude investigativa estaria muito menos submetido a uma lógica curricular rígida, excludente, e portanto teria uma maior possibilidade de assumir alunos desafiadores. A possibilidade do diretor abrir espaço para opiniões divergentes também é fundamental para a construção de um diálogo autêntico e participativo (ALMEIDA, 2003).

Como último aspecto a ser abordado coloca-se a questão dos alunos com necessidades educacionais especiais. De acordo com o relato da diretora, na ocasião da sua chegada, havia um aluno com síndrome de Down, portanto, com uma deficiência mais circunscrita. Os demais alunos considerados preocupantes não apresentavam um diagnóstico específico, sendo que a dificuldade colocada em relação ao trabalho com estes alunos relacionava-se a supostas questões de aprendizagem. Ao chegar na escola, Marcela encontrou este cenário, e relata ter tido a iniciativa de conversar com os pais destes alunos, como transcrito no trecho de entrevista abaixo: 
$\mathrm{D}=\mathrm{O}$ que eu notava, o que a gente começou a descobrir, é que tinha muitos alunos que estavam aí dois, três, quatro anos na quarta série, e não estavam alfabetizados. E daí, o que fazer com esses alunos? Os pais já não vinham mais, estavam desacreditados. Na conversa com os pais a gente começou a orientá-los de que às vezes essa criança precisava de uma ajuda, a gente começou a fazer algum encaminhamento.

$\mathrm{P}=$ Encaminhamento

D = Para o psicólogo, todas as especialidades, e os pais tinham muita resistência de ter que estar levando as crianças. Principalmente porque tinham casos de alunos que não era bem deficiência, mas necessidades especiais de aprendizagem.

( $\mathrm{D}$ = diretora; $\mathrm{P}$ = pesquisadora $)$

Após a entrevista, debati com Marcela sobre a pertinência de ações como encaminhamentos de alunos para atendimento psicológico em serviços de saúde. Ponderei que me parecia que estes alunos respondiam em consonância a um contexto onde sua aprendizagem não era tomada como o objetivo principal, pois muitas vezes estes alunos ficavam fora da classe, vagando pelos corredores, e a atitude da escola não ia muito além de queixar-se à família.

Como membro da equipe técnica, testemunhei casos semelhantes durante meu trabalho com a escola. Lembro-me de Eduardo, um menino inteligente e cheio de vivacidade, acompanhado pelo Conselho Tutelar por questões familiares. A professora tinha muitas queixas sobre ele. Fui observar uma aula. A menor menção de um aluno virar-se para o lado e perguntar algo a um colega era criticada pela professora, numa atitude que há muito tempo eu não presenciava em uma sala de aula, onde até as professoras mais tradicionais acabam por ter atitudes mais flexíveis. Ao final da observação, a professora em questão disse-me que não via sentido na minha observação, 
uma vez que os problemas de indisciplina do aluno aconteciam fora da sala de aula, pois lá ela o mantinha sob controle. Qual seria a expectativa dela em relação ao trabalho com ele fora da sala, ou seja, fora da posição de aluno? A diretora anterior, Cecília, perguntou certa vez a Eduardo o que poderia ajudálo, e ele respondeu que gostaria de organizar um campeonato de futebol na escola. Enfim, são micro-recortes de um cenário onde o aluno era tratado como um problema, como um desvio da norma.

Assim, questionava-me se a escola, ao encaminhar os alunos para o psicólogo da saúde, teria claro que esta ação não a eximia da principal responsabilidade quanto à aprendizagem dos mesmos. Ponderei ainda com Marcela que observei iniciativas dela no sentido de investir intensamente na aprendizagem dos alunos, como os grupos de estudo e turmas de apoio, indicando que a escola assumia a responsabilidade pela aprendizagem dos alunos, mas gostaria de apontar este aspecto da sua fala que provocou em mim esta reflexão após a entrevista. Segundo Marcela, a escola entende que a aprendizagem dos alunos é sua tarefa. Ela concordou comigo quanto às condições encontradas quando chegou, e que estas contribuíam para a não-aprendizagem do aluno. Ponderou, contudo, que o encaminhamento para a UBS (Unidade Básica de Saúde) funciona como um apoio para a família, que lá recebe uma orientação mais ampla, como encaminhamentos para oftalmologista, por exemplo. Argumentou que os alunos vivem situações familiares complexas, cuja intervenção está fora do campo de ação da escola, e que a saúde pode ser um recurso nesses casos. Entende ainda que o munícipe tem direito de acesso à saúde, e este encaminhamento pode ser uma porta de entrada para este exercício. Ambas concordamos, no entanto, que esta ação pode até ocorrer de forma paralela, mas nunca substitui o trabalho principal da escola com o aluno, que é do campo pedagógico, no processo de ensino e aprendizagem. 


\section{d. Relação com a o sistema educacional}

O tema da influência do contexto maior proporcionado pelo sistema escolar e suas orientações aparece na fala de Marcela em diferentes situações que merecem ser exploradas. Inicialmente, as limitações impostas pelo sistema são sentidas na experiência como professora de uma aluna com necessidades educacionais especiais: a falta de uma orientação adequada, de acompanhamento e de formação alia-se à falta de espaços escolares adequados, ou medidas como redução do número de alunos em sala, segundo o seu relato. Como diretora, as limitações voltam a ser sentidas, desta vez na falta de uma orientação mais sistemática que respalde as ações escolares. A falta de orientações do sistema municipal específicas para o tratamento de questões relativas a avaliação de alunos com necessidades educacionais especiais, por exemplo, faz com que a escola se sinta pouco amparada ao tomar decisões baseadas nas orientações federais, por serem de natureza mais amplas. Segundo ela, o apoio oferecido é insuficiente, mas as cobranças são muitas:

\footnotetext{
A lei das adaptações curriculares, que é a questão do tempo, que é a questão do olhar, não é isso? Pelo menos eu olho isso, a gente discute a questão do tempo da criança, do olhar, da não retenção... Seus objetivos são diferentes, se eu for cobrar dele alfabetização ele não vai sair da primeira série. [...] É como se brecasse o nosso trabalho, tira o nosso chão. Você sabe que tem a LDB, você sabe que é um direito da criança estar aqui, mas em algumas ações que você tem você é questionada o tempo todo [...] Que atendimento a diversidade é esse? Acho que atendimento a diversidade é além, não é? Você tem que estar contemplando as crianças, o ritmo, o tempo de cada um.
}

Pela fala da diretora pode-se inferir que, ainda que a educação inclusiva seja hoje uma realidade inquestionável, os sistemas têm feito pouco no sentido de adotar medidas concretas para sua efetiva implantação, o que coincide com o apontamento de Sage (1999) sobre a necessidade do sistema apoiar claramente as transformações que a escola se empenha em realizar, bem 
como faz pensar na fragilidade que as mudanças implantadas efetivamente possuem. Algumas iniciativas costumam ser tomadas no que se refere à formação de professores, e até mesmo na adequação física dos espaços escolares, porém o acesso ao currículo continua sendo o grande vilão, com o predomínio de formas de avaliação tradicionais e práticas pouco inclusivas, que não se dirigem a um grupo mais a alunos separadamente. Os que ousam agir de forma diferente enfrentam resistências dentro do próprio sistema.

\section{e. O envolvimento da comunidade e pais como estratégia da gestão democrática}

Uma outra questão trazida pela diretora é a aproximação da comunidade à escola, e as dificuldades vividas neste processo. Inicialmente, Marcela relata uma postura bastante resistente dos pais:

Os pais chegavam com duas pedras na mão. Então a gente gastava 30
minutos, 40 minutos primeiro para tirar as pedras das mãos dos pais,
porque eles chegavam aqui muito armados, eles chegavam totalmente
armados. Quando você chamava um pai pra conversar ele tinha muita
resistência, porque achava que a gente ia humilhar o filho dele, não sei
o que se passava na cabeça dele. Então você tinha que tirar toda essa
barreira [...]. Era aquele trabalho de sedução, e foi de um a um.
Aqueles pais com os filhos com maiores dificuldades foram
chamados de um a um e feito este trabalho, que começava a surtir
algum efeito na terceira, na quarta conversa, não era assim na
primeira conversa. Na primeira conversa eles vinham "tá bom, tá
bom". Aí na segunda você chamava e eles já vinham com o coração
mais aberto, com o peito mais aberto, aí você conseguia.

Por esta fala, pode-se pensar que a resistência apresentada pelos pais ao chamado da escola poderia se basear tanto em suas experiências pessoais como alunos, mas também em situações mais atuais, como pais de 
alunos. A prática de algumas escolas de convocar os pais para criticá-los e apontar as suas falhas é, infelizmente, bastante comum. A reformulação da reunião com pais é colocada como uma forma de alcançar uma maior proximidade com a escola:

Para trazer a comunidade nós começamos a mudar a dinâmica da reunião de pais, que deixou de ser aquela reunião onde o professor só passava recados, e recados que colocavam seu filho lá para baixo, e passou a ser formativa. A professora começou a falar do trabalho dela, das suas dificuldades em sala, das ansiedades, do que ela precisava, então a reunião passou a ser mais formativa. E numa sala que tem inclusão o professor trabalha isso com todos os pais.

O trabalho inclusivo da escola estar na pauta da reunião com pais é uma conquista importante, mostrando preocupação em envolver a comunidade com a questão (TEZANI, 2004). Também foi comentado pela diretora o trabalho com os pais de alunos sobre importância de orientarem seus filhos para um acolhimento sem preconceitos para todos os colegas:

É importante a professora trabalhar isso na reunião de pais, até para os pais trabalharem com o filho aquela questão do não rótulo, “ah, ele não sabe nada", aquelas piadinhas que os alunos às vezes fazem. $\mathrm{O}$ que acontece na escola é que a criança passa a não ser tratada diferente, ela passa a ser do grupo.

Sobre o funcionamento dos órgãos colegiados, como o Conselho de Escola e a APM, a diretora relata que a equipe gestora realizou um trabalho sistemático no sentido de ampliar a participação dos pais, uma vez que os órgãos colegiados tinham até então um caráter meramente burocrático:

Nós queríamos a comunidade na escola, mas não apenas nos eventos. No ano passado, quando a gente fez o dia da família, fizemos uma exposição das atividades das crianças. Foi muito legal, os pais viram o que as crianças eram capazes de fazer, porque muitas vezes o professor faz coisa maravilhosas e fica na sala. Então a gente usou isso 
para chamar a comunidade. Os pais viram as produções das crianças, nós tivemos muitos elogios. E eu senti que a partir dessa exposição, dessa feira que teve aqui na escola, a comunidade começou a chegar.

É interessante apontar que a escola utiliza como recurso para a aproximação da comunidade o foco por excelência do seu trabalho: a atividade pedagógica. Muitas escolas acham que oferecer palestras para os pais é uma forma de aproximá-los, mas dificilmente refletem que por trás da palestra acaba sendo veiculada a mensagem de que os pais não têm um saber, e que é a escola que detém boas respostas e sabe a forma correta de educar. Ao utilizar seu trabalho pedagógico com os alunos como estímulo a participação da comunidade, a escola reafirma seu papel, e possibilita que os pais reafirmem-se no seu. Outra avaliação positiva é feita pela diretora em relação às reivindicações expressas pelos pais, como por exemplo, o pedido de estagiária de apoio à inclusão pelos pais, incluindo os que não têm filhos com necessidades educacionais especiais:

Então isso é legal, porque eles não estão pensando só nos aspectos quantitativos, como material, porque antigamente a APM só reivindicava isso; eles estão reivindicando aspectos qualitativos. Quando fala-se na estagiária de inclusão ele sabe que vai ser um benefício para a criança e para o filho dele, porque a professora vai conseguir se articular melhor, pelo menos foi o que eles apresentaram como justificativa para a gente: tanto para atender melhor o filho dele, para intervir melhor com o filho dele, quanto com aquele aluno que precisa, que seja de inclusão.

Assim, a participação da comunidade na escola é avaliada como tendo sido aumentada não só do ponto de vista do número de pais participantes, mas quanto à qualidade das reivindicações apresentadas. 


\subsection{Segundo momento: o tema de fundo e os focos de análise}

É considerado aqui como tema de fundo a temática mais presente nas falas analisadas e nos temas recortados, como um ponto de referência que reaparece, indicando, portanto, a sua importância nesta análise: o coletivo.

A estratégia grupal, coletiva, é um tema norteador na fala de Marcela. Está presente quando conta sua primeira experiência de trabalho com uma aluna com necessidades educacionais especiais, onde busca apoio no coletivo escolar. Retorna quando expõe seu objetivo principal ao entrar na escola José Paulo Paes, que é conquistar o grupo de professores. Buscar a participação dos pais, e definir ações pedagógicas com o grupo de professores são alguns dos exemplos que podem ser encontrados na sua fala.

O recurso ao grupo como estratégia recorrente de atuação mostrada na ação de Marcela indica uma forma de democratizar decisões de trabalho, propiciando uma participação mais ativa dos envolvidos e dividindo o peso da responsabilidade entre todos (ARAÚJO, 2002). Uma forma de gerenciamento democrática poderá ser sentida em todos os campos da atividade escolar, como o administrativo, organizacional, etc.

No campo das relações pedagógicas, e mais precisamente na implantação de uma cultura escolar inclusiva, será vivenciado como a divisão da responsabilidade pelo trabalho com os alunos pelo grupo de professores, não localizando o foco decisório no trabalho de um professor isoladamente, ou na imposição de decisões da diretora, como no caso da atribuição dos alunos com necessidades educacionais especiais para os professores que voluntariamente se disponham a fazer este trabalho. Outra indicação desta orientação para o trabalho coletivo é a ação de solicitar aos pais que orientem os filhos a não discriminar seus colegas por conta de suas diferenças significativas. A ação indica uma preocupação em agir em vários 
campos que atravessam o acolhimento e o pertencimento do aluno à escola, e conta para isso com uma intervenção coletiva dos vários pais, alunos e professores, ou seja, todos os envolvidos no trabalho da escola (SAGE, 1999).

Retomando agora os focos propostos para a análise, podese admitir que a cultura escolar atual que é possível ser percebida no discurso da diretora é a de uma escola que busca a ação coletiva como uma forma de operar nas diferentes esferas de atuação, seja pedagógica, administrativa ou das relações com a comunidade. As necessidades individuais dos alunos e dos pais parecem ser consideradas, e a postura da escola é a de compreender seus motivos de forma empática, ao invés de acusá-los, fazer cobranças ou lamentarse.

Em relação ao tratamento dado à educação inclusiva nesta determinada cultura escolar, cabe pensar o quanto esta cultura escolar pode ser uma cultura escolar inclusiva. Neste sentido, uma cultura escolar pode ser considerada inclusiva quando ela tem como foco o pertencimento dos alunos à escola, e não questiona se o lugar deles é ali ou não. Esta situação não aparece, ou seja, não é cogitado que possa haver outro lugar melhor para o aluno do que a escola regular. Pelo contrário, as ações relatadas visam a permanência do aluno na escola. Assim, é bastante positivo o fato de Marcela não considerar a alternativa da escola especial para o encaminhamento do aluno.

Quando se falou do Gabriel, o aluno com síndrome de Down, a maior preocupação, anterior à aprendizagem, era a da relação do mesmo com o espaço escolar. Examinando a questão dentro das suas inerentes contradições, a preocupação com a aprendizagem, que seria desejável aparecer como foco principal, também poderia resultar como uma forma de exclusão. A aprendizagem, ao ser tomada como o fator fundamental para avaliar os benefícios que o aluno está colhendo com a escolarização (considerando-se a tendência da escola em a avaliar a aprendizagem pelos seus resultados 
objetivos e mensuráveis), poderia levar a escola a pensar: se ele "não aprende" como os outros alunos, o que está fazendo aqui? Esta questão é bastante complexa, talvez uma das mais complexas que envolvem os debates sobre educação inclusiva: a aprendizagem de alunos com necessidades educacionais especiais, ou, para radicalizar o aspecto aqui discutido, a aprendizagem de alunos com deficiência intelectual. Levando em consideração as experiências que vivenciei em minha prática, bem como a linha teórica deste trabalho, e deixando claro a impossibilidade de aprofundar aqui esta discussão, é possível supor que a resposta se encontra nos contextos de aprendizagem oferecidos, sendo a problematização da proposta curricular da escola uma importante via de acesso nesta reflexão. Este tema é bastante intricado, e por sua complexidade geralmente se encontra fora das possibilidades de reflexão sobre a prática que as equipes escolares possuem, quer seja pela falta de tempo, quer seja pela falta de interesse que os sistemas escolares demonstram sobre a questão. Os sistemas escolares não parecem estar convencidos da importância desta discussão, pois a educação inclusiva ainda é vista como algo a ser feito somente em alguns casos de alunos, bem como o currículo como algo que precisa apenas ser adaptado para estes casos e não transformado para atender a todos os alunos. Assim, diante de um problema tão profundo com implicações desconhecidas, a escola envolvida na tarefa de uma educação inclusiva muitas vezes age de forma intuitiva. Neste cenário, a capacidade de tolerar o não-saber, e de assumir uma postura investigativa, buscando de forma coletiva algumas respostas, é fundamental para atacar as primeiras questões que surgem, ou seja, as resistências ao recebimento do aluno $\mathrm{e} o$ acolhimento às diferenças significativas - o que, se é ainda incipiente em relação ao tamanho da tarefa, é sem dúvida um começo imprescindível. Portanto, dentro de uma cultura escolar sujeita a práticas e currículos tradicionais, olhar o aluno que não aprende da forma convencional como um desafio necessário e que é do cômputo da escola produz uma pequena e bem-vinda transformação nesta cultura. 
Quanto aos fatores pessoais da diretora em relação com a cultura escolar, é possível perceber algumas interlocuções. A busca pelo trabalho coletivo, marcante em sua trajetória profissional, é um grande foco presente em diversas ações como diretora, sendo também um ponto importante na gestão escolar favorecedor do diálogo (NOGUEIRA, 1993) e da descentralização de decisões (ARAÚJO, 2002). Outra questão que merece destaque é o fato de que tanto Marcela quanto sua antecessora eram iniciantes na função de direção escolar. Gostaria de destacar uma fala interessante de Marcela junto ao grupo de professores:

O grupo também estava ansioso, porque era uma pessoa que eles nem sabiam, não era uma diretora, era uma pessoa, a Marcela, que ninguém nunca ouviu falar, então havia esta ansiedade por parte do grupo. Aí eu cheguei, conquistando o grupo. Fui muito aberta para o grupo, falei: gente, eu não sei trabalhar com fundamental, minha experiência com fundamental é em outra rede, mas estou aqui para a gente construir junto a nossa história. (grifo nosso)

Ao chegar como uma pessoa, e não como uma diretora, Marcela demonstra uma disposição em estabelecer um vínculo horizontal com o grupo, e não direcionado de cima para baixo. Pode assim desarmar as defesas iniciais, e compor com o grupo um coletivo em busca da melhor atuação. É claro que esta intenção perde todo o sentido se ficar apenas enunciada em palavras, devendo ser verificada em ações. Estas acontecem, como por exemplo, ao discutir a atribuição dos alunos com necessidades educacionais especiais junto com os professores. Outra questão que pode ser relacionada com a sua primeira experiência como diretora é seu pensar como professora, dando destaque à preocupação com a aprendizagem, como visto num trecho da entrevista citado anteriormente e que reproduzo abaixo:

Quando me chamaram [para assumir o cargo de diretora] fiquei muito em dúvida, porque eu amo a sala de aula e o contato com as crianças. 
Tanto que hoje, na escola, uma coisa que eu prezo muito é a parte pedagógica, eu não consigo me desligar da parte pedagógica.

A contradição apontada por Paro (2002) e Saviani (2000) entre o diretor-educador e o diretor-administrador é concretamente experimentada por Marcela, quando parece colocar um certo distanciamento da parte pedagógica como atributo relacionado ao papel de diretor às voltas com questões administrativas. Ter como principal preocupação a parte pedagógica da escola é sentido algo esperado do diretor. Sabe-se, contudo, que muitos diretores são "tragados" pelas questões administrativas da escola (ROMÃO E PADILHA, 2001); outros fazem esta opção de forma consciente, deixando a parte pedagógica a cargo do coordenador pedagógico. No caso de Marcela, assim como no da diretora anterior, as questões administrativas são colocadas em segundo lugar em relação às pedagógicas, indicando uma concepção de aprendizagem mais voltada para a função da escola como educadora, como apontado por Saviani (2000). Para os diretores assim posicionados, a luta com a burocracia da instituição escolar é uma constante, pois o sistema educacional tem suas demandas burocráticas sempre atualizadas (REIS, 2000; LYRA, 2003), o que exige dos profissionais uma afinação renovada de sua postura como educador.

A experiência como professora também motivou Marcela a assumir atitudes empáticas com as dificuldades encontradas pelos professores de alunos com necessidades educacionais especiais:

Eu sei por mim, pela experiência que tive, eu tive uma aluna de inclusão: para o professor também é desgastante. Então a gente avalia o lado profissional, porque o professor, querendo ou não, entra com a emoção, e chega uma hora que ele também atinge o seu limite.

Proporcionar boas condições de trabalho ao professor através da possibilidade de falar com o grupo e com os gestores sobre as dificuldades e encontrar nesta discussão boas formas de intervenção é um 
objetivo de Marcela enquanto diretora, relacionado com sua experiência profissional. Estes e outros exemplos podem ser utilizados para refletir que os fatores pessoais vividos na trajetória profissional, bem como as concepções educacionais do diretor e a sua história pessoal de relação com a educação inclusiva e com a gestão democrática do ensino acabam influenciando a cultura escolar. Como anteriormente discutido, o diretor é uma peça num contexto mais amplo, e tem sua ação subordinada a vários fatores, como as orientações legais do sistema, por exemplo. Contudo, ele pode facilitar ou dificultar sua efetivação pelas suas ações, pode submeter-se ou pode lutar pelo que acredita, como quando Marcela queixa-se de falta de orientação e apoio do sistema em relação às diretrizes de avaliação. Assim, parece haver um espaço onde é possível movimentar-se dentro de um sistema mais ou menos rígido, e este espaço é diretamente proporcional às concepções do diretor enquanto educador, e na forma como ele as traduz em ações.

Finalmente, ao avaliar se é possível estabelecer, a partir da entrevista analisada, relações entre concepção de educação inclusiva e gestão democrática, a resposta é afirmativa, uma vez que, neste caso específico, a atuação da diretora se dá de forma a democratizar decisões, e isso se desdobra nos encaminhamentos relativos aos alunos com necessidades educacionais especiais. Como exemplo, pode-se retomar a situação de trancar a sala, onde a diretora procura atuar com a professora através do convencimento e do esclarecimento, ao invés da imposição de decisões tomadas de forma centralizada, ou com o trabalho em reuniões com pais onde o assunto da educação inclusiva é considerado por todos. 


\section{Algumas conclusões possíveis}

Cada escola deveria ser uma comunidade coletivamente responsável pelo sucesso ou fracasso de cada estudante. O grupo de educadores, ao invés de professores individualmente, deveria dividir a responsabilidade pela educação de crianças com necessidades especiais. Pais e voluntários deveriam ser convidados assumir participação ativa no trabalho da escola. Professores, no entanto, possuem um papel fundamental enquanto administradores do processo educacional, apoiando as crianças através do uso de recursos disponíveis, tanto dentro como fora da sala de aula.

(Declaração de Salamanca, 1994)

No momento de extrair algumas conclusões possíveis sobre as reflexões aqui desenvolvidas, cabe iniciar com uma breve retrospectiva do caminho até aqui percorrido.

O objetivo proposto foi investigar o papel do diretor escolar na formação de uma cultura escolar inclusiva a partir de uma abordagem sócio-histórica. Partindo deste objetivo, foi preciso investigar o que é cultura escolar, e isso foi feito partindo-se do conceito de cultura, que foi ampliado a partir de definições no campo da antropologia até chegar-se à definição de cultura escolar.

Tentar conceituar o termo cultura, de grande complexidade e abordado na literatura extensamente do ponto de vista teórico, 
serviu aqui a dois objetivos: primeiro, estabelecer que a escola possui uma cultura própria, que é constituída pelos que dela fazem e fizeram parte, e portanto também pelo diretor; segundo, definir que a escola é um importante meio de acesso à cultura da sociedade onde está, portanto, torna participante da cultura aqueles que participam da escolarização. Cultura então foi tomado tanto como aquilo que caracteriza as formas de ser e proceder específicas de uma dada instituição escolar, como também aquilo que caracteriza uma determinada sociedade e se transmite através das instituições sociais, no caso, a instituição escolar. Tanto em uma acepção quanto em outra, o olhar dirige-se ao contexto: o micro-contexto escolar, o macro-contexto social, sendo ambos caracterizados por formas culturais específicas.

Feita esta análise, o foco foi direcionado para a cultura escolar, pensando-se como a mesma se constitui e influencia as práticas escolares que ali se desenrolam, destacando-se entre elas a inclusão escolar de alunos com necessidades educacionais especiais, ou, mais precisamente de acordo com o recorte feito, de alunos com deficiência. Um certo jeito de ser, um certo clima, uma forma mais ou menos específica de funcionar caracterizam cada escola, ou seja, cada uma tem uma certa cultura, com práticas, rituais, procedimentos, sejam estes tácitos ou explícitos, que indicam como a inclusão escolar é vista e praticada em uma dada escola.

Novamente, pode-se fazer a ligação entre a micro-cultura escola e a macro-cultura sociedade: a escola vai revelar de forma mais ou menos intensa como a sociedade inclui ou exclui este aluno, que tem como uma das formas de participação na sociedade maior estar numa escola dentro desta sociedade. Estar ou não na escola, incluído entre todos os alunos, é uma forma de estar incluído dentro da sociedade, uma vez que a escola é uma das instituições sociais mais importantes de participação em uma sociedade - nela, está vivificada a forma como esta sociedade, esta cultura é preservada, pela transmissão às gerações mais novas. Estar incluído na escola, podendo 
participar deste processo cultural, é um fator fundamental para a humanização - é como se a escola confirmasse que esse indivíduo "é um dos nossos", pertence à humanidade, à categoria de ser humano, e pode portanto compartilhar do nosso saber.

Feito o destaque ao contexto, passou-se à justificativa do recorte teórico escolhido, o da psicologia sócio-histórica. O contexto vai intervir de forma decisiva na humanização do indivíduo - como os indivíduos são socializados, em uma dada sociedade, irá se refletir na própria constituição única e pessoal de cada ser socializado. Daí a reflexão a partir da contribuição de Vigotski, com especial destaque para os estudos do autor no campo das deficiências. Deslocamos o olhar da falta, do déficit: o ser humano com deficiência é socializado, pertence a esta cultura, mas de forma mediada pela sua deficiência, que age como um filtro entre ele e a cultura, projetada para as pessoas ditas normais, como lembra Vigotski (1929). Assim, não vamos considerar a deficiência como coisa em si, mas como algo que toma forma específica a partir da relação dialética entre indivíduo e contexto - como em todo processo de humanização, para qualquer indivíduo.

Como o contexto pesquisado aqui é o escolar, foi proposto então que a escola vai ter uma influência na forma como o aluno com deficiência vai se desenvolver em relação ao seu processo de escolarização. Se oportunidades são dadas ou recusas são feitas, isso irá reverberar na maneira como este aluno-indivíduo está se desenvolvendo e aprendendo - ou deixando de fazê-lo, ou ainda fazendo-o de forma restrita - naquele ambiente.

Assim, foram feitas análises de fatores contextuais que contribuem para a formação da cultura escolar, ou ainda, para a formação de uma cultura escolar inclusiva. A partir das proposições encontradas na literatura consultada, procurou-se observar a escola como organização com cultura própria (NÓVOA, 1995), com práticas culturais escolares diversificadas 
configurando relações (LIBÂNEO, 2001; TEIXEIRA e PORTO, 1997; SILVA JR. e FERRETTI, 2004), com um determinado clima escolar (BRITO, 1997; BRUNET, 1995), com relações dinâmicas com a cultura em que se insere (GUSMÃO, 2003; DEMARTINI, 2003; MIRANDA, 2004) e como espaço sociocultural (DAYRELL, 1997). Assim, pesquisou-se alguns documentos que pudessem dar indícios sobre as especificidades culturais da escola pesquisada, analisando-se desde o plano municipal de educação e a forma como a educação inclusiva é pensada, aproximando-se de forma sucessiva até chegar ao projeto pedagógico da escola, de forma a proporcionar uma visão panorâmica de alguns dos vários fatores que se somam e interpenetram para constituir uma determinada forma de uma escola existir, e de um aluno com deficiência poder estar dentro dela.

Explorou-se o importante conceito de ambiente escolar inclusivo (SEKKEL, 2003), conceito coerente com o que é postulado por Vigotski acerca da importância da coletividade no desenvolvimento da criança (1929, 1931a, 1931b), de maneira que algumas das variáveis que compõem este ambiente pudessem ser refletidas, com especial destaque para a qualidade das relações humanas que se estabelecem em determinado ambiente escolar. Muitas e diversificadas variáveis poderiam ser citadas, desde os professores até as amizades estabelecidas pelos alunos, passando pela proposta pedagógica e o bairro, mas a variável aqui destacada é a contribuição do diretor para a configuração do contexto escolar, ou seja, da cultura escolar que, conforme aqui postulado, irá influenciar o desenvolvimento do aluno com deficiência portanto, buscou-se compreender a contribuição do diretor para a construção do ambiente escolar inclusivo proposto por Sekkel (1993).

Levantou-se na seqüência várias contribuições na literatura para a questão da gestão escolar e da gestão democrática, destacandose principalmente os trabalhos de Libâneo (2001) e Paro (2001a, 2001b, 2002). Inicialmente, conjeturou-se que as características pessoais do diretor interferem na forma como a cultura escolar se efetiva, o que foi de certa forma confirmado 
neste estudo de caso. A explicação proposta para isso seria o papel central do diretor na instituição escolar, havendo uma suposição de que este papel central poderia se transformar em papel centralizador, caso o diretor lhe desse este caráter, uma vez que a democratização da gestão escolar - ou seja, repartiremse poderes e responsabilidades - é algo ainda incipiente.

A distinção entre central e centralizador precisa ser feita. Central assume a feição de principal, importante, com acesso aos vários níveis de decisão. Portanto, se o diretor entende que a gestão democrática é algo a ser efetivamente implantado, seu papel central, no sentido de liderança, favorece esta ação, uma vez que poderá propor e incentivar ações democráticas. Centralizador, no entanto, remete ao significado contrário, ou seja, o diretor como alguém por quem todas as decisões devem passar a fim de serem aprovadas. O diretor, portanto, pode assumir seu papel central e colocá-lo a favor da democratização da escola, dividindo e delegando atribuições, ou pode assumir um papel centralizador e puxar para si as decisões e encaminhamentos do trabalho escolar. Em nenhum dos dois casos o diretor é uma figura menos importante: ao distribuir responsabilidades ou centralizá-las, seu papel gerenciador é destacado. Por qual caminho irá optar é uma decisão influenciada pela sua história pessoal, certamente, mas é preciso considerar a importância do contexto. Assim, um sistema de ensino que favoreça a formação em serviço de diretores visando afinar suas concepções dentro de uma mentalidade democrática e inclusiva pode fazer diferença no tipo de propostas adotadas pela direção escolar.

A democratização da gestão e a educação inclusiva também se configuram como estreitamente relacionadas a partir do que foi aqui analisado, confirmando a proposição inicial de que quanto mais democrática for a escola, mais inclusiva será. Para tanto, tome-se a proposta de abertura da escola para todos, ou seja, a democratização do ensino. Se a escola é para todos, certamente deverá abarcar os alunos com necessidades educacionais especiais 
no processo de escolarização, quer seja devido à deficiência, quer seja por questões psicológicas, sociais ou culturais, para citar apenas algumas possibilidades. Uma escola inclusiva é, antes de tudo, uma escola democrática. Assim, uma cultura escolar inclusiva será mais efetivamente implantada se as relações escolares forem permeadas pelo respeito ao outro e por uma postura democrática da gestão escolar.

Não se deve equivocadamente concluir que é preciso buscar indivíduos com características pessoais democráticas para ocupar funções importantes para a cultura escolar inclusiva como a de direção. Devese, isso sim, investir na produção de contextos escolares que favoreçam a construção de práticas democráticas, para que os professores e alunos vivenciem-nas de forma concreta. O diretor de amanhã é o professor de hoje e o aluno de ontem, cujas experiências de participação numa sociedade democrática são importantes para a consolidação de suas concepções de educação e de práticas não discriminatórias.

Os sistemas educacionais também devem assumir sua importante cota de responsabilidade, investindo na construção de contextos escolares democráticos, seja através da formação continuada de seus profissionais, seja através da mensagem subliminar que passam através das opções governamentais quanto às políticas públicas: um sistema não pode se autoproclamar inclusivo e manter condições desfavoráveis para a efetivação da inclusão de alunos com necessidades educacionais especiais, como classes numerosas, currículos excludentes ou prédios sem acessibilidade. Ao examinar a documentação do município que aborda a questão da educação inclusiva, pôde-se observar a reiterada referência à importância da mesma. Se este é um indício importante para concluir que há uma preocupação do governo com a questão, o mesmo não deve ser tomado como suficiente, uma vez que entre a enunciação formal de intenções e a mudança efetiva de práticas se observa grande distanciamento. A prática analisada neste trabalho, contudo, afina-se 
com os princípios democráticos enunciados nos documentos oficiais que, em contrapartida, podem respaldar esta prática, propiciando um ambiente mais favorável a diretores afinados com a proposta educacional inclusiva.

Em nossa opinião, a luta pela escola inclusiva é a mesma velha luta pela escola de qualidade. Se os problemas estruturais da educação baixos salários, classes superlotadas, formação de professores, só para citar alguns - estivessem minimizados, certamente a inclusão de alunos com necessidades educacionais especiais causaria um impacto menor. Do ponto de vista pedagógico, se a escola refletisse em sua prática um pouco do que o discurso pedagógico vem pregando há tempos - pedagogia de projetos, agrupamentos produtivos, pesquisa ativa, estudo de meio, uso de tecnologias, partir do que o aluno sabe e de sua experiência de vida, a educação inclusiva estaria de certa forma melhor estabelecida, e os ajustes seriam menos radicais do que os que se propõem em face de práticas pedagógicas mais tradicionais.

A pressão social pela democratização e pela inclusão desequilibra as estruturas tradicionais da escola. Decorre daí uma incorporação superficial destes alunos, uma vez que a ampliação do atendimento a todas as crianças não é acompanhada de uma qualidade no ensino. Como Aquino (1996), porém, defendemos que a falta de qualidade da escola não é uma decorrência da democratização da mesma, não se devendo confundir democratização com deterioração do ensino. Fatores como a falta de estrutura crônica da educação, ou os interesses políticos e econômicos envolvidos nas propostas de reformas educacionais, explicaram e continuam a explicar a falta de qualidade da escola brasileira destinada ao atendimento das classes populares de forma mais convincente do que o suposto acesso à escola por todos os alunos. A inclusão de alunos com diferenças significativas na escola regular reabre velhas feridas da educação pública, superficialmente cicatrizadas e que continuam demandando uma solução. 
Ao apontar estas contradições, as dificuldades se ressaltam, mas os caminhos se delineiam. E há que trilhá-los. 


\section{7}

\section{Referências bibliográficas}

ALMEIDA, J. G. A intervenção (im)possível no cotidiano de uma escola: relato do trajeto de um diretor de escola na rede pública municipal (resumo) Tese (doutorado). Faculdade de Educação, Universidade de São Paulo, 2003.

AQUINO, J. R. G. A desordem na relação professor-aluno: indisciplina, moralidade e conhecimento. In: . Indisciplina na escola: alternativas teóricas e práticas. São Paulo: Summus, 1996. p. 39-55.

ARANHA, M. S. F. Paradigmas da relação da sociedade com as pessoas com deficiência. In Revista do Ministério Público do Trabalho, Ano XI, n. ${ }^{0}$ 21, março, 2001, pp. 160-173.

ARAÚJO, U. F. A construção de escolas democráticas. São Paulo: Moderna, 2002. p. $42,44,73$.

BARDIN, L. Análise de conteúdo. Lisboa: Edições 70, 2002. 231p.

BARROS, C. O. T. O papel do diretor escolar na formação em serviço: um estudo da proposta de formação da Secretaria Municipal de Educação de São Bernardo do Campo. Dissertação (mestrado). Faculdade de Educação, Universidade de São Paulo São Paulo, 2004. 
BRANDÃO, C. R. O que é educação. 10. ed. São Paulo: Brasiliense, 1983, 120p.

BRASIL. Educação inclusiva: v. 3: a escola. Coordenação geral SEESP/MEC. Organização Maria Salete Fabio Aranha. Brasília: MEC /SEESP, 2004. 26 p.

Parâmetros Curriculares Nacionais: Adaptações Curriculares. Secretaria de Educação Fundamental. Secretaria de Educação Especial. Brasília : MEC /SEF/SEESP, 1998. $62 \mathrm{p}$.

BRITO, A. M. A gestão escolar e sua relação com o projeto pedagógico: estudo da experiência realizada nas escolas da rede estadual de ensino de Mato Grosso do Sul 1995-1998 (resumo). Dissertação (mestrado). UFSCar Universidade Federal de São Carlos, São Carlos, 2002.

BRITO, R. L. G. L. Clima e cultura de escola: uma questão de administração escolar. In: PINTO, F. C. F., FELDMAN, M. e SILVA, R. C. Administração escolar e política de educação. Piracicaba: Unimep, 1997. p. 207-216.

BRUNET, L. Clima de trabalho e eficácia da escola. In: Nóvoa, A. (coord.) As organizações escolares em análise. 2. ed. Lisboa, Portugal: Publicações Dom Quixote, 1995. p. 123-140.

BRUNO, L. E. N. B. Relações de Trabalho e Teorias Administrativas In: A autonomia e a qualidade do ensino na escola pública. São Paulo: FDE, 1995. p. 125-139. (Série Idéias n. 16)

BOGDAN, R.; BIKLEN, S. Investigação qualitativa em educação. Portugal: Porto Editorial, 1994. p. 134-139. 
CAPELO, M. R. C. Diversidade sociocultural na escola e a dialética da exclusão/inclusão. In: GUSMÃO, N. M. M. (org.) Diversidade, cultura e educação: olhares cruzados. São Paulo: Biruta, 2003. p. 83-105.

CASTRO, M. L. S. A Gestão da Escola Básica: conhecimento e reflexão sobre a prática cotidiana da diretora de escola municipal. Em Aberto: gestão escolar e formação de gestores. V. 17, n. 12. Brasília: MEC/INEP, 2000. p. 71-87.

CHARLOT, B. Da relação com o saber: elementos para uma teoria. Porto Alegre: Artes Médicas Sul, 2000. p. 51-76.

DAYRREL, J. A escola como espaço sócio-cultural. In: DAYRREL, J. Múltiplos olhares sobre educação e cultura. Belo Horizonte: UFMG, 1996. p. 136-161.

DEMARTINI, Z. B. F. Culturas escolares: algumas questões questões para a história da educação. In: GUSMÃO, N. M. M. (org.) Diversidade, cultura e educação: olhares cruzados. São Paulo: Biruta, 2003. p. 83-105.

DUARTE, N. A anatomia do homem é a chave da anatomia do macaco: A dialética em Vigotski e em Marx e a questão do saber objetivo na educação escolar. Educação e Sociedade. v.21 n.71 Campinas julho 2000, p. 79-115.

Vigotski e o aprender a aprender. 2 ed. Campinas: Autores Associados, 2001, p. 2-3.

DUROZOI, G. e ROUSSEL, A. Dicionário de filosofia. Campinas: Papirus, 1993. p.115. 
EVANS, P. Algumas implicações da obra de Vygotsky na educação especial. In:

DANIELS, H. (org.) Vygotsky em foco: pressupostos e desdobramentos. $2^{\mathrm{a}}$ ed. Campinas: Papirus, 1995. p. 69-89.

FRIGOTO, G. Introdução. In: GADOTTI, M. e ROMÃO, J. (Orgs.). Autonomia da escola: princípios e propostas. 2. ed. São Paulo: Cortez, 1997.

GADOTTI, M. Escola cidadã. 7. ed. São Paulo: Cortez, 2001. p. 52 e 57.

GALERA, J. M. B. A implementação de políticas educacionais e a gestão como um processo de inovação: a experiência na região sudoeste do Paraná, sul do Brasil. Universidade Estadual de Campinas, Faculdade de Educação (resumo). Tese (doutorado). Campinas: 2003

GLATTER, R. A gestão como meio de inovação e mudança nas escolas. In: Nóvoa, A. (coord.) As organizações escolares em análise. 2. ed. Lisboa, Portugal: Publicações Dom Quixote, 1995. p. 141-161.

GUSMÃO, N. M. M. Os desafios da diversidade na escola. In: GUSMÃO, N. M. M. (org.) Diversidade, cultura e educação: olhares cruzados. São Paulo: Biruta, 2003. p. 83-105.

HALL, S. A centralidade da cultura: notas sobre as revoluções culturais do nosso tempo (1997). Disponível em http://www.educacaoonline.pro.br/ art_a_centralidade_da_cultura.asp. Acesso em 13 set. 2005.

KASSAR, M. C. M. Ciência e senso comum no cotidiano das classes especiais. Campinas: Papirus, 1995. 96p. 
LACERDA, S. C. Uma escola chamada Zacaria: história, amores, rumores, ousadias (resumo). Dissertação (mestrado). Faculdade de Educação, Universidade de São Paulo, São Paulo, 2003.

LIBÂNEO, J. C. Organização e gestão da escola: teoria e prática. Goiânia: Alternativa, 2001. p. 31-186.

LIMA, E. C. A. S. A escola e seu diretor: algumas reflexões. O papel do diretor e a escola de $1^{0}$ grau. São Paulo: FDE, 1996. p. 117-124. (Série Idéias n. 12)

LOPES, N. F. M. A função do diretor do ensino fundamental e médio: uma visão história e atual. Dissertação (mestrado). Faculdade de Educação, Universidade Estadual de Campinas, Campinas, 2003.

LUCCHESI, M. A. S. O diretor da escola pública, um articulador. In: PINTO, F. C. F., FELDMAN, M. e SILVA, R. C. Administração escolar e política de educação. Piracicaba: Unimep, 1997. p. 231-248.

LYRA, Z. A. A gestão e o gestor da educação do Estado de São Paulo: um estudo de caso sobre a conformação após 1995. Dissertação (mestrado) Faculdade de Educação, Universidade Estadual de Campinas, Campinas, 2003.

MANTOAN, M. T. E. Capítulo 5 - Abrindo a escola às diferenças. In: (org.) Pensando e fazendo educação de qualidade. São Paulo: Moderna, 2001. p. 109-123. 
MATTOS, M. J. V. M. A reforma educacional de Minas Gerais: a implementação da autonomia escolar (resumo). Dissertação (mestrado). Faculdade de Educação, Universidade Estadual de Campinas, Campinas, 1999.

MENDES, E. G. Raízes históricas da educação inclusiva. Trabalho apresentado em agosto de 2001, durante os Seminários Avançados sobre Educação Inclusiva, ocorrido na UNESP de Marília. (mimeo)

MIRADOR Encyclopaedia Britannica do Brasil, São Paulo - Rio de Janeiro 1987, vol. 7, p. 3107-3133.

MIRANDA, M. G. O processo de socialização na escola: a evolução da condição social da criança. In: LANE, S. T. M. e CODO, W. (orgs.). Psicologia social: o homem em movimento. 13 ed. São Paulo: Brasiliense, 2004. p. 125-135.

MONTEIRO, A. A. O diretor de escola e a elaboração do projeto político pedagógico: o pensar e o agir (resumo). Dissertação (mestrado). UFSCar Universidade Federal de São Carlos, São Carlos, 2003.

MORETO, J. A. A educação continuada do diretor de escola: avaliação da política implementada pela Secretaria Municipal de Educação de Campinas, no período de 1994 a 2000. Dissertação (mestrado). Faculdade de Educação, Universidade Estadual de Campinas, Campinas, 2002.

NOGUEIRA, M. J. Diretor dirigente: a construção de um projeto pedagógico na escola pública. O papel do diretor e a escola de $\mathbf{1}^{\text {o }}$ grau. São Paulo: FDE, 1996. p. 57-67. (Série Idéias n. 12) 
NÓVOA, A. Para uma análise das instituições escolares. In: Nóvoa, A. (coord.) As organizações escolares em análise. 2. ed. Lisboa, Portugal: Publicações Dom Quixote, 1995. p. 13-43.

OMOTE, S. Deficiência e não-deficiência: recortes de um mesmo tecido. Revista Brasileira de Educação Especial, v. 1, n. 2, Piracicaba, 1994. p. 65-73.

PARO, V. H. Capítulo IV - Administração escolar e transformação social. In: Administração escolar: introdução crítica. 11 ed. São Paulo: Cortez, 2002. p. 133-135.

- Direção escolar e coordenação pedagógica: práticas e vivências. In: PARO, V. H. Escritos sobre educação. São Paulo: Xamã, 2001a. p. 117-120.

. Gestão democrática da escola pública. 3 ed. São Paulo: Ática, 2001b. p. $15-28$.

- Gestão escolar, ética e liberdade. In: PARO, V. H. Escritos sobre educação. São Paulo: Xamã, 2001A. p. 49-52.

O conselho de escola na democratização da gestão escolar. In: PARO, V. H. Escritos sobre educação. São Paulo: Xamã, 2001a. p.79-90.

PÉREZ GÓMEZ, A. I. A aprendizagem escolar: da didática operatória à reconstrução da cultura na sala de aula. In: SACRISTÁN, J. G. e PÉREZ GÓMEZ, A. I. Compreender e transformar o ensino. 4. ed. Porto Alegre: ArtMed, 1998. p. 53-66. 
PRIETO, R. G. Políticas públicas de inclusão: compromissos do poder público, da escola e dos professores (2002). Disponível em <http://www. educacaoonline.pro.br/art_politicas_publicas_de_inclusao.asp.> Acesso em 19 jul. 2005.

REGO, T. C. Configurações sociais e singularidades: o impacto da escola na constituição dos sujeitos. In: OLIVEIRA, M. K., SOUZA, D. T. R. e REGO, T. C. (orgs.) Psicologia, educação e as temáticas da vida contemporânea. São Paulo: Moderna, 2002. p. 47-76

REIS, M. G. F. A. O compromisso político-social do diretor como educador (resumo). Dissertação (mestrado). UFSCar Universidade Federal de São Carlos, São Carlos, 2000.

ROMÃO, J. E. ; PADILHA, P. R. Diretores escolares e a gestão democrática da escola. In: GADOTTI, M. e ROMÃO, J. E. (orgs.) Autonomia da escola: princípios e propostas. 4. ed. São Paulo: Cortez e Instituto Paulo Freire, 2001. p. 91-102.

SÁ, E. D. ; RAHME, M. M. F. Escola Plural: um projeto político de gestão pedagógica. In: MANTOAN, M. T. E. (org.) Pensando e fazendo educação de qualidade. São Paulo: Moderna, 2001. P. 71-90.

SAGE, D. D. Estratégias administrativas para a realização do ensino inclusivo. In: STAINBACK, $S$; STAINBACK, W. Inclusão: um guia para educadores. Porto Alegre: Artes Médicas Sul, 1999. p. 129-141. 
SANT'ANA, I. M. Educação inclusiva: concepções de professores e diretores. In: WITTER, G. P. (org). Psicologia e educação: professor, ensino e aprendizagem. Campinas: Alínea, 2004.

SAVIANI, D. Papel do diretor de escola numa sociedade em crise. In:

Educação: do senso comum à consciência filosófica. 13 ed. Campinas: Autores Associados, 2000. p. 207-210.

Pedagogia histórico-crítica: primeiras aproximações. Campinas: Autores Associados, 2003. p. 76-77; p. 95-98; p. 118.

SCHNECKENBERG, M. A Relação entre política pública de reforma educacional e a gestão do cotidiano escolar. Em Aberto: gestão escolar e formação de gestores. V. 17, n. 12. Brasília: MEC/INEP, 2000. p. 113-124.

SEKKEL, M. C. A construção de um ambiente inclusivo na educação infantil: relato e reflexão sobre uma experiência. Tese (doutorado). Instituto de Psicologia da Universidade de São Paulo, São Paulo, 2003.

SILVA Jr, J. R. ; FERRETTI, C. J. O institucional, a organização e a cultura da escola. São Paulo: Xamã, 2004. p. 49-81

SILVA, C. C. Uma contribuição ao estudo da distribuição do poder na relação pedagógica democrática (resumo). Dissertação (mestrado). Faculdade de Educação, Universidade de São Paulo, São Paulo, 2001. 
SOUZA, A. L. L. Estado e educação pública popular (resumo). Tese (Doutorado). Faculdade de Educação, Universidade de São Paulo, São Paulo, 2002.

STAKE, R. E. Case studies. In: DENZIN, N. K. e LINCOLN, Y. S. Handbook of qualitative research. $2^{\mathrm{a}}$. Ed. Thousand Oaks, London, New Delhi: Sage Publications, Inc., 2000. p. 435-454.

TEIXEIRA, M. C. S.; PORTO, M. R. S. Gestão da escola: novas perspectivas. In: PINTO, F. C. F., FELDMAN, M. e SILVA, R. C. Administração escolar e política de educação. Piracicaba: Unimep, 1997. p. 231-248.

TEZANI, T. C. R. Caminhos para a construção da escola inclusiva: a relação entre a gestão escolar e o processo de inclusão. Dissertação (mestrado). UFSCar Universidade Federal de São Carlos, São Carlos, 2004.

TORRES, A.; GARSKE, L. M. N. Diretores de escola: o desacerto com a democracia. Em Aberto: gestão escolar e formação de gestores. V. 17, n. 12. Brasília: MEC/INEP, 2000. p. 60-70.

UNESCO. Declaração de Salamanca e Enquadramento da Acção na Área das Necessidades Educativas Especiais. Conferência Mundial Sobre Necessidades Educativas Especiais: Acesso e Qualidade. Organização das Nações Unidas para a Educação, a Ciência e a Cultura. Ministério da Educação e Ciência de Espanha: Salamanca, Espanha, 1994. 48p. 
VALE, J. M. F. Administração educacional e escolar. In: A autonomia e a qualidade do ensino na escola pública. São Paulo: FDE, 1995. p. 107-113. (Série Idéias n. 16)

VIANNA, I. O. A. Administração da escola pública: um desafio pedagógico e político (resumo). Tese (doutorado). Faculdade de Educação, Universidade de São Paulo, São Paulo, 1992.

VIGOTSKI, L. S. O comportamento anormal. In: L. S. Psicologia pedagógica. Porto Alegre: ArtMed, 2003. p. 257-266.

O comportamento social e sua relação com o desenvolvimento da criança. In: VIGOTSKI , L. S. Psicologia pedagógica. Porto Alegre: ArtMed, 2003. p. 197-207.

VYGOTSKI, L. S. (1928). Anomalías del desarrollo cultural del nino. In: Fundamentos de defectología. Obras escogidas, vol. V. Madri, 1997. p. 347.

_. (1929). Los problemas fundamentales de la defefectología contemporánea. In: VYGOTSKI, L. S. Fundamentos de defectología. Obras escogidas, vol. V. Madri, 1997, p. 11-39.

- (1931a). Acerca de los procesos compensatorios em el desarollo del nino mentalmente retrasado. In: VYGOTSKI, L. S. Fundamentos de defectología. Obras escogidas, vol. V. Madri, 1997, p. 131-151. 
(1931b) La colectividad como factor del desarrollo del nino deficiente. In: VYGOTSKI, L. S. Fundamentos de defectología. Obras escogidas, vol. V. Madri, 1997. p. 213-233.

VYGOTSKY, L. S. Formação social da mente. São Paulo: Ed. Martins Fontes, 1988.

XIMENES, M. R. Atuação do diretor em sua relação com a comunidade usuária da escola: um estudo de caso (resumo). Dissertação (mestrado). Faculdade de Educação, Universidade de São Paulo, São Paulo, 2003. 